
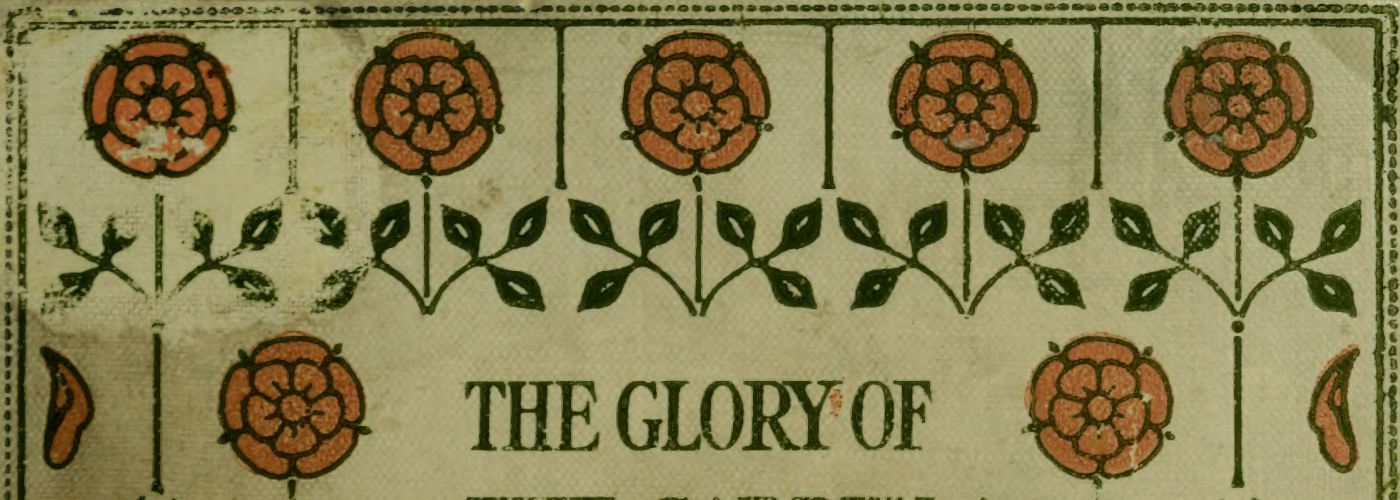
\%
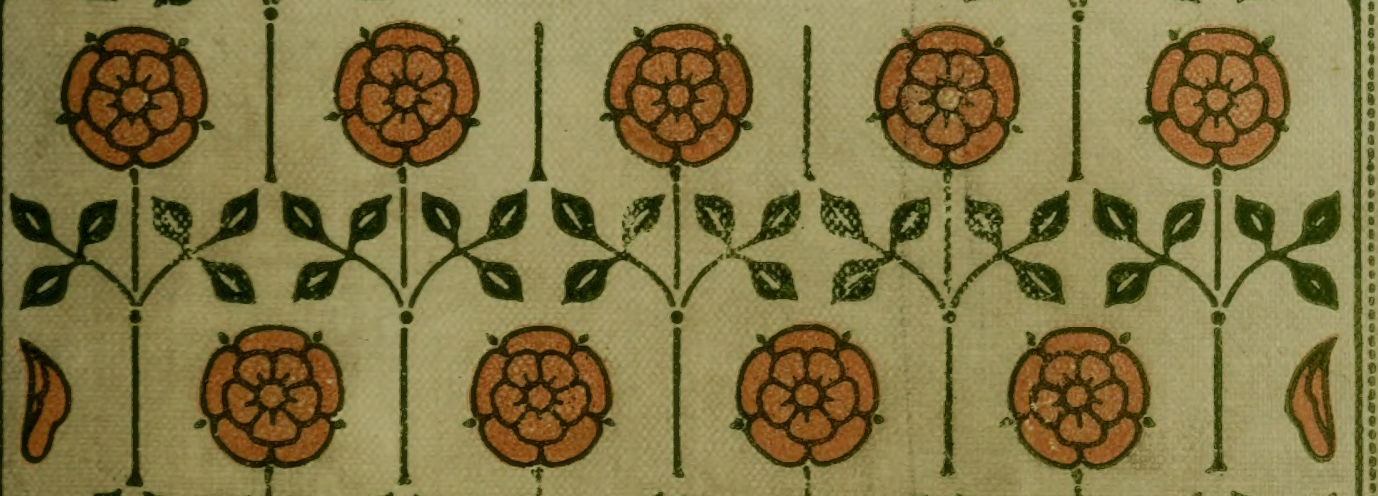

\%ัर a on ara
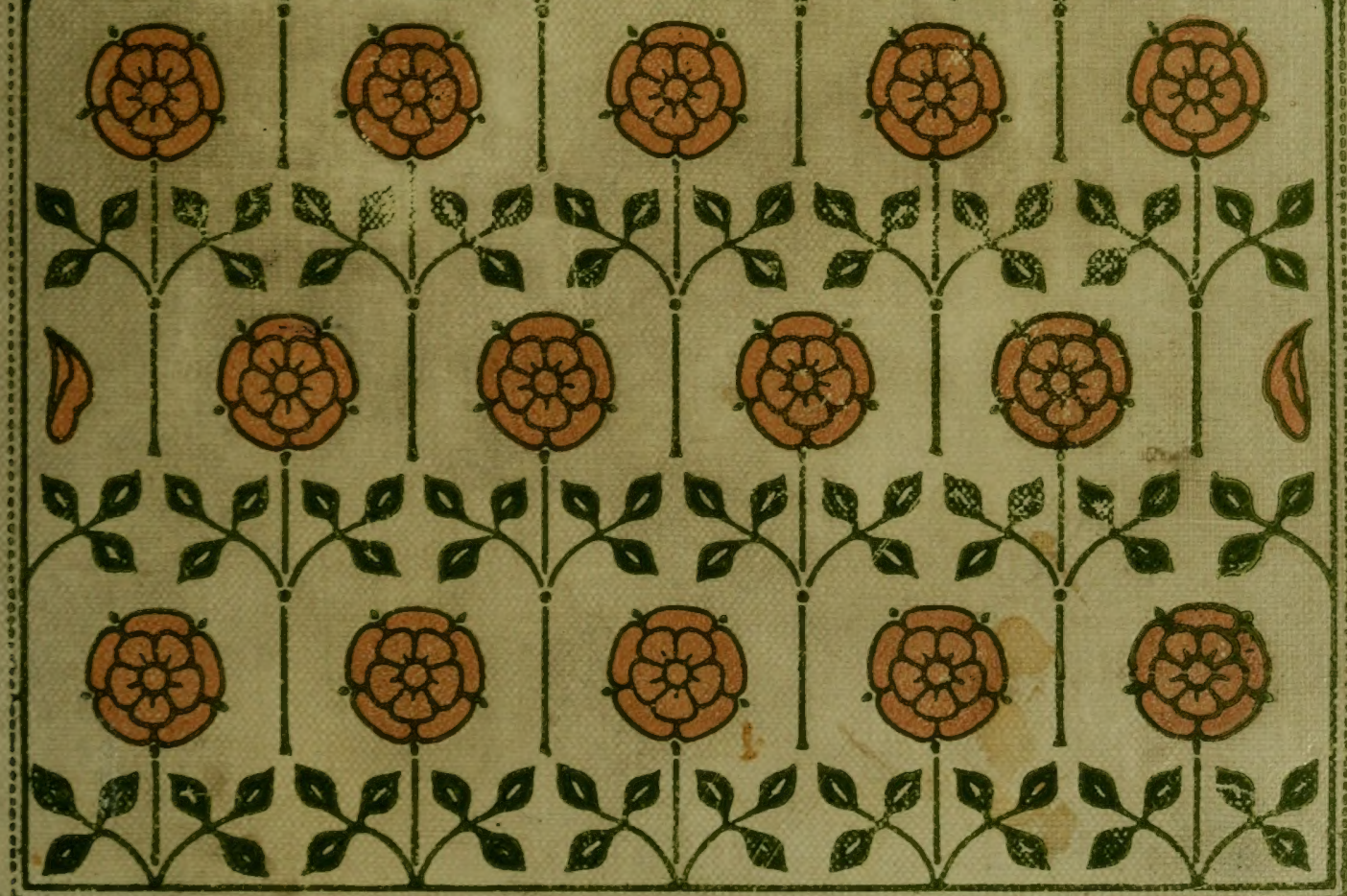


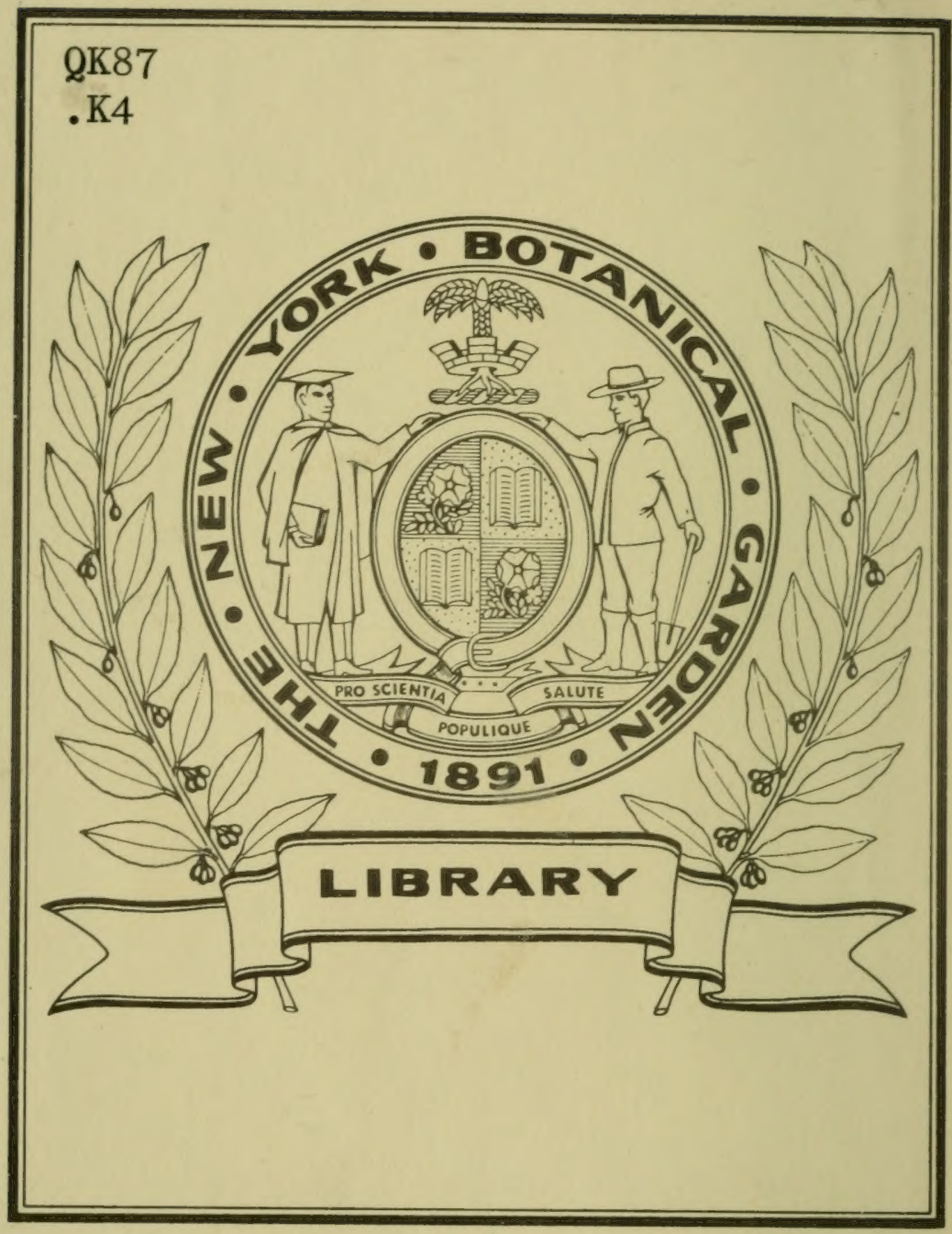





THE GLORY OF THE GARDEN 


\section{OTHER BOOKS ON GARDENS}

MOSTLY CONTAINING ILLUSTRATIONS IN COLOUR

\section{THE CHARM OF GARDENS}

By Dion Clayton Calthrop.

32 full-page Illustrations in Colour by

BEATRICE PARSONS and others.

\section{THE GARDENS OF ENGLAND}

By E. T. Cook.

16 full-page Illustrations in Colour by BEATRICE PARSONS.

\section{PLANT LIFE}

By Rev. Charles A. Hall.

50 full-page Illustrations in Colour by

C. F. NEWALL, and 24 page Illustrations from photographs.

\section{THE CALL OF THE OPEN}

A Nature Anthology.

Selected and Edited by Leonard $\mathrm{H}$. STOWELl.

I6 full-page Illustrations in Colour.

\section{GARDENS IN THEIR SEASONS}

By C. von Wyss.

32 Illustrations in Colour and 32 in Black and White.
THE CHILDREN'S BOOK OF GARDENING

By Mrs. A. Sidgwick and Mrs. PAYNTER.

8 full-page lllustrations in Colour by Mrs. CAYLey-Robinson.

GARDENS OF THE GREAT MUGHALS

By Mrs. C. M. Villiers Stuart.

40 page Illustrations ( 16 in Colour), also 8 Ground Plans.

\section{BLACK'S GARDENING DICTIONARY}

Edited by E. T. Ellis, F.R.H.S.

With Contributions by the leading

Gardening Experts and Specialists of to-day.

THE NATURAL HISTORY OF THE GARDEN

(In the "Peeps at Nature" Series.)

By Percival Westell.

I6 full-page Illustrations, 8 being in Colour.

A. AND C. BLACK, LTD., 4,5 \& 6 SOHO SQUARE, LONDON, W. I

\section{AGENTS}

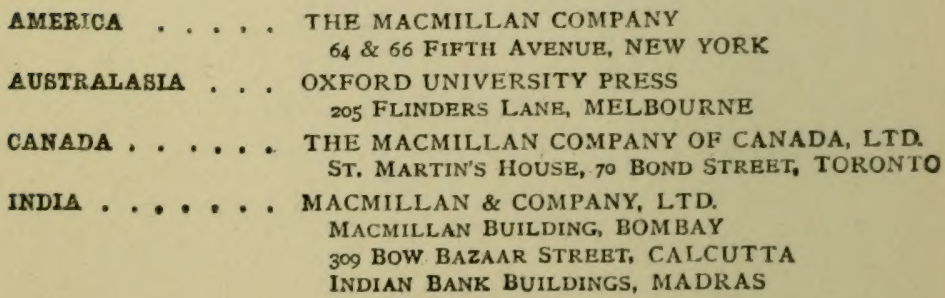




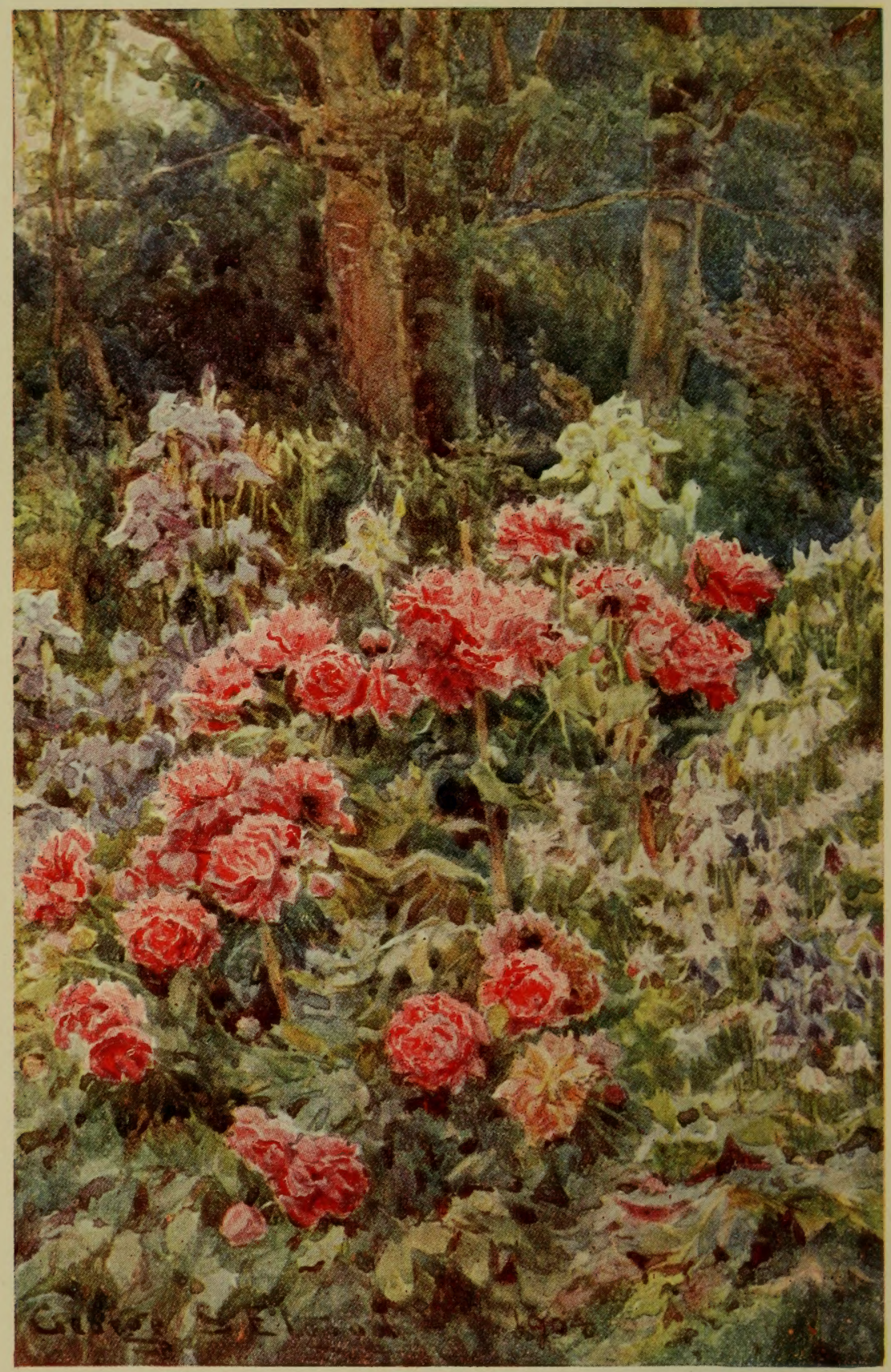

PEONIES AND IRIS, 

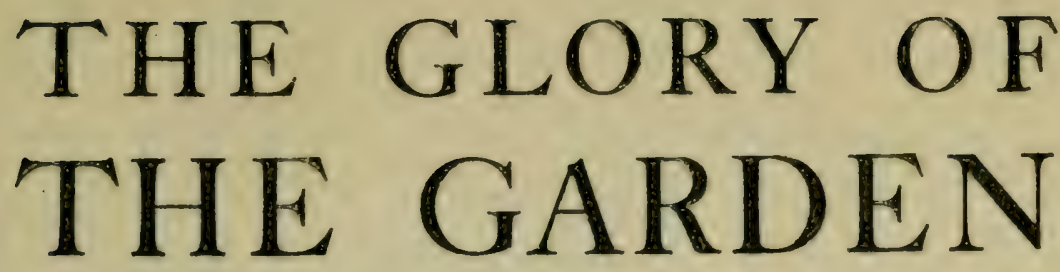

By

M. G. KENNEDY-BELL

F.R.H.S.

"In my garden I spend my days; in my library I spend my nights. My interests are divided between my geraniums and my books. With the flower I am in the present; with the book I am in the past."

Alexander Smith.

A. \& C. BLACK, LTD.

4, 5 छ 6 SOHO SQUARE, LONDON, W. I I923 
PRINTEN IN GREAT BRITAIN BY BILLING AND SONS, LTD., GUILDFORD AND ESHEF. 


\section{Contents}

CHAPTER

PAGE

I. THE HISTORY OF GARDENING - - I

II. PLANT BREEDING, IN ITS RELATION TO GARDENING - $\quad$ - $\quad$ - $\quad$ - 9

III. A DAY IN THE LIFE OF A PLANT - I8

IV. HERBS AND THEIR ORIGIN - - 27

V. THE PATRON SAINTS OF GARDENING - 40

VI. SOME BEE LORE

VII. SOME BIRD LORE

VIII. SOME TREE LORE

IX. SOME WEATHER LORE - - - 78

X. THE MOON AND PLANT GROWTH - 83

XI. MAGICAL PLANTS - - - 90

XII. WITCHES AND THEIR FLOWER LORE - 99

XIII. THE DEVIL'S PLANTS - - - IO9

XIV. FAIRIES AND THEIR FLOWER LORE - II9

XV. OUR LADY'S FLOWERS - - - $\quad$ - 130

XVI. FLOWERS OF THE SAINTS -

XVII. FLOWER LEGENDS OF "SAINTLY FAME" I 47

XVIII. LEGENDS OF NATIONAL FLOWERS - I59

XIX. LEGENDS OF MYTHOLOGICAL FAME - I69

XX. LEGENDS OF FIR AND PINE TREES - I80 



\section{THE GLORY OF THE GARDEN}

\section{CHAPTER I}

THE HISTORY OF GARDENING

"As gardening has been the inclination of Kings and the choice of Philosophers, so it has been the common favourite of public and private men; a pleasure of the greatest, and a care of the meanest; and, indeed, an employment and possession for which no man is too high or too low."-Sir WM. TeMple.

THE art and craft of gardening is undoubtedly the oldest of all human occupations, and in the long ages of time that have passed since the first gardener, our forefather Adam, practised the art, first for pleasure, and afterwards as a means of subsistence, gardening has never failed to have a magic fascination for the rich and poor of all nations.

Noah, we are told, was very proficient in the cultivation of the Vine; Jacob in growing Vines, Figs, and Almonds; Solomon in making gardens, orchards, and vineyards.

The ancient Egyptians, Assyrians, Chinese, Greeks, and Romans seem to have been experts in the fashioning of gardens and the cultivation of fruits and vegetables.

The gardens of that early period were enclosed by walls or thick hedges to protect the crops from prowling animals, and the chief crops grown seem to have been the Vine, Fig, Pomegranate, Walnut, 
Almond, Medlar, and Quince. Also Lettuce, $\mathrm{Cu}-$ cumber, Melons, Onions, Leeks, and Garlic galore.

In the hot, dry climate of Palestine, watering was an indispensable operation, and so reservoirs for irrigating the land had always to be provided. In ancient Persia and Assyria, gardens were fashioned and maintained on a very large scale near all the large cities.

The famous Hanging Gardens of Babylon were the great wonder of all the world. They consisted of twenty plateaux rising one above the other, and resting on walls 22 feet in thickness, and each planted with trees, or other vegetation, kept in constant growth by artificial watering.

In Egypt also the gardens were very elaborately fashioned, much sculpture and masonry entering into their formation; and in these gardens they grew many kinds of fruit, all of which had to be constantly watered by means of irrigation from the Nile.

The Greeks were very famous gardeners, and they seem to have taken special delight in having fine expanses of beautifully-kept grass; fruit trees were much cultivated, and the favourite flowers would seem to have been Roses, Lilies, and Narcissi.

The Romans were most keen gardeners, and grew many of the popular vegetables of the present day with great success. Also, they understood fully the art of manuring and forcing, and they may be said to have brought horticulture and agriculture to their highest perfection at that period of the world's history.

So far as our own country is concerned, there can be little doubt that we owe the early introduction of horticulture to the Romans. 
When they had finally subjugated the ancient Britons and peace prevailed, history tells us that the Roman settlers planted vineyards and orchards of apples, pears, figs, and mulberries; also they grew corn extensively for home use and for export.

In the twelfth century it is recorded that vineyards flourished in the Vale of Gloucester, apple orchards were plentiful in the fertile district of Worcester, and market gardens existed at Fulham. These were simple patches or enclosures, within walls, planted with fruits, vegetables, and herbs.

The Monks of the Middle Ages were the real pioneers of gardening, and it is to their skill and knowledge that we owe much. Their superior education and general habits made it possible for them to bring skilled method into the work, and gardening as an " art" may be rightly said to date from the monastery gardens.

Also, the monks were naturally in the habit of travelling a good deal, and so had the chance of seeing new plants cultivated in other countries, which they could secure and grow in their own gardens.

In the reign of Edward III. the art of gardening began to be taken seriously in hand. Gardens were laid out on a more ornamental scale, and plants for medicinal purposes were cultivated extensively.

The first book on gardening- "De Yconomia de Housbrandia," by Walter de Henley-appeared in the sixteenth century, and others soon followed, including that of Thomas Tusser, who detailed the work of the garden and farm in quaint and curious rhyme. 


\section{4 \\ THE GLORY OF THE GARDEN}

In Henry VIII.'s reign the gardens of Nonsuch and Hampton Court were laid out with regal splendour, and in Elizabeth's time the Potato, Tomato, Tea, and many other useful and ornamental trees and plants were introduced from foreign countries.

Evelyn, a great writer and traveller, did much to extend and popularise the practice of gardening. Gerarde, the famous surgeon and botanist, lived at this time, and published his excellent "Herbal," a work still valued very highly, and full of sound information. Jobn Parkinson, a little later, published "Paradise in Sole Paradisus Terrestris," a work which gave a great impetus to gardening.

In the eighteenth century much progress was made, and people of wealth began to lay out gardens on a magnificent scale, and form parks, and plant trees for ornament and use.

Botanical gardens were formed at Chelsea, Cambridge, and $\mathrm{Kew}$, and greenhouses, glazed with glass and artificially heated, were first brought into practical use. It seems from records, though, that the professional gardener of that period was much lacking in skill and intelligence; he could cultivate the ordinary crops, but failed hopelessly in the art of growing the choicer vegetables and fruit, and so these had to be imported from Belgium and Holland.

The Chelsea Pbysic Garden was founded by the "Society of Apothecaries of London," which society was incorporated by Royal Charter in 1606, and was then united with the Grocers' Company, an ancient City guild.

An interesting record of the Chelsea Physic Garden in 1685 is given to us by John Evelyn: 
"7th August.-I went to see Mr. Watts, keeper of the Apothecaries' garden of simples at Chelsea, where there is a collection of innumerable rarities of that sort particularly, besides many annuals, the tree bearing jesuits' bark, which had done such wonders in quartan agues. What was very ingenious was the subterranean heat, conveyed by a stove under the conservatory, which was all vaulted with brick, so as he has the doors and windows open in the hardest frosts, secluding only the snow."

The Chelsea garden was framed, in the main, on the pattern of the herbalists' gardens, and one of the principal aims of its founders was the arrangement of plants in a systematic manner, that is, according to their families.

At the close of the seventeenth century, the plants were arranged according to the systems of Ray and Tournefort, and in practice this scheme is still partially carried out, inasmuch, as trees and shrubs are generally grouped apart from herbaceous plants, for matters of convenience.

Towards the end of the eighteenth century, the Linnean classification gradually supplanted the systems of Ray and Tournefort, and this was again superseded by Decandolle and Lindley about the middle of the nineteenth century. Since the reorganisation of the garden in 1902, the sequence of the natural orders for the herbaceous plants is that of Bentham and Hooker's "Genera Plantarum."

From 1836 to 1853 , the fame of the Chelsea garden was at its zenith, largely owing to the great activity of John Lindley, who occupied the chair of Professor of Botany and Præfectus Horti during that period. But in 1853 the Society found it 
was seriously hampered by the expenses involved in this work, and they decided to relieve the strain by working the garden more economically. The lectures were discontinued, the office of Præfectus Horti was abolished, and the cultivation of plants requiring artificial heat was abandoned. The garden was saved from total oblivion during this period by its curator, Thomas Moore, who had been elected to the post in 1848 , on the recommendation of Lindley. Thomas Moore was co-editor of "The Treasury of Botany" with Lindley, a work which has made the name of the Chelsea garden famous throughout the world.

The rôle of the garden is still chiefly an educational one; specimens of living plants are supplied to a number of colleges and schools, and the laboratory is used for physiological work by the students of the Royal College of Science.

The present Royal Botanic Gardens at Kew are the result of the fusion of two Royal domains-(I) Richmond Gardens, and (2) the original Kew Gardens, the latter corresponding roughly to the private grounds of Kew House, a substantial private house, which was demolished in 1803 . This fusion, contemplated by an Act of Parliament, and giving George III. power to cause the lane separating the two gardens " to be shut up and discontinued," was finally completed in 1802 .

In I 823, George IV. acquired the western portion of Kew Green, including an old road which led there from Brentford Ferry. By this means part of the present herbarium, and the whole of its site, the old Kew Gardens, the former Richmond Gardens, became a single Royal domain; and this 


\section{THE HISTORY OF GARDENING}

fusion proved, incidentally, to be the first step towards the opening up of Kew to the public.

The three chief objects which Kew has aimed at from the outset are:

I. To make of Kew Gardens a pleasure-ground which would stimulate the interest of the general public in the vegetable kingdom and its products.

2. To encourage and render assistance to scientific botanists, travellers, merchants, and manufacturers.

3. To train plant collectors and gardeners for home, colonial, and foreign service.

The Kew training is very thorough, consisting of practical work and lectures, with the added benefit that the student has of becoming familiar with Kew's marvellous collection of plants.

The lectures comprise a course in physics and chemistry as applied to botany and geology; another in general botany; a third on economic plants and their products; and a fourth on geographical botany. During his stay at Kew the young gardener has to collect, mount, and name a herbarium of 250 specimens himself, and at the end of two years he is granted a Kew certificate, provided his work has been satisfactory.

So from this brief summary it can quite easily be seen that it is during the last century that gardening in all its branches made such a great advance, due to the efforts of many eminent experts, such as Thomas Andrew Knight, who did so much in the improvement of the varieties of hardy fruit; Sir Joseph Paxton, the talented gardener, and designer of the gardens at Chatsworth and the Crystal Palace; Charles Darwin, who rendered such vast service to botany and the improvement 
of plants by his researches and studies as to the origin of species; to say nothing of Mendel, whose discoveries went far to revolutionise our knowledge of genetic science and heredity. Darwin's achievement so far exceeded anything that had been thought possible before, that what should have been but a beginning, was hailed as the completed work.

Professor Bateson, in his book on "Mendel's Principles of Heredity," says: "Had Mendel's work come into the hands of Darwin, it is not too much to say that the history of the development of evolutionary philosophy would have been very different from that which we have witnessed."

"God Almighty first planted a garden. And, indeed, it is the purest of human pleasures; it is the greatest refreshment to the spirit of man, without which buildings and palaces are but gross handiworks. And a man shall ever see that when ages grow to civility and elegance, men come to build stately, sooner than to garden finely, as if gardening were the greater perfection. I do hold it in the royal ordering of gardens, there ought to be gardens for all the months in the year, in which severally things of beauty may be then in season."

Francis Bacon (Lord Verulam). 


\section{CHAPTER II}

PLANT BREEDING, IN ITS RELATION TO GARDENING

"Evolution ever climbing after some ideal good, And Reversion ever dragging evolution in the mud."

Tennyson.

Among the biological sciences, the study of heredity must necessarily occupy a central position, and although as gardeners we are not directly concerned with the application of science, we must nevertheless perceive that in no branch of knowledge is research more likely to increase our power over nature.

Whilst the experimental "study of the species" problem was in great activity, the Darwinian writings appeared. Evolution, from being an unsupported problem, was shown to be plainly deducible from ordinary experience, and the reality of the process was no longer doubted.

But Mendel, and his working out of the Mendelian principles, has carried us far beyond the beginning that Darwin made.

Darwin indeed paved the way, and, as it were, laid the foundation stones, but to Mendel was given the golden key which should unlock the door into the mysteries of the laws governing the study of plant breeding and genetics.

History of Mendel.-Mendel was born in 1822, in the "Kuhland" district of Austrian Silesia. 
It is recorded of his father that he took special interest in fruit culture, and initiated his son at an early age into the mysteries of grafting.

Gregor Mendel attended a government school in the village, where his talent was soon obvious. The result of this was that, when he was only eleven years old, he was sent to Leipzig, and here he distinguished himself so much that he was sent on to Troppau, although the parental resources were rather severely taxed by this effort.

At Troppau one of the instructors was an Augustinian, and possibly his description of the scholarly quiet of the cloisters may have turned Mendel's thoughts in this direction. For very shortly he became a candidate for admission to the Augustinian house of St. Thomas in Brünn. $\mathrm{He}$ was admitted to the monastery, and elected with a view to his taking part in the educational work; in 1847 he was ordained priest. At the expense of the cloister he was sent in $185 \mathrm{I}$ to the University of Vienna, where he remained till I853, studying mathematics, physics, and natural science. On returning to Brünn he became a teacher, and he appears to have taken great pleasure in this work, and to have been quite extraordinarily successful in instructing, and also interesting, his pupils.

In 1868 he was elected Abbot, or Prälat, of the monastery. The experiments which have made his name famous throughout the world were carried out in the large garden belonging to the monastery.

$W$ ith the views of Darwin, which at that time were coming into prominence, Mendel did not find himself in full agreement, and he embarked on his experiments with Peas, which he continued for 


\section{PLANT BREEDING}

eight years. His largest undertaking, besides the work on Pisum, was an investigation on the heredity of Bees. He had fifty hives under observation, but the notes which he is known to have made on these experiments can nowhere be found, and it is now feared that they must have been destroyed, possibly inadvertently.

The types of the great discoverers are most varied. The wild, uncertain, rapid flash of genius, the scattered, half-focussed daylight of generalisation, and the steady, slowly-perfected ray of penetrative analysis, are all lights in which truth may be seen. Mendel's faculty was of the latter order.

From the fragmentary records of him in his biography we can form a fairly true idea of the man, with his clear head, strong interest in practical affairs, obstinate determination, and power of pursuing an abstract idea.

The total neglect of his work during his lifetime is known to have been a serious disappointment to him. $\mathrm{He}$ is reported constantly to have said: "Meine Zeit wird schon kommen" (My time will surely come).

Mendelian Theories.-The case which illustrates Mendel's methods in the simplest way is that in which heredity in respect of height was studied.

Mendel took a pair of Sweet Peas, of which one was tall ( 6 to 7 feet), and the other dwarf ( 9 to I 8 inches). These two were then crossed together. The cross-bred seeds thus produced grew into plants which were always tall, having a height not sensibly different from that of the pure tall variety from which the cross was made. In Mendelian terms, this first, cross-bred, filial generation is 


\section{THE GLORY OF THE GARDEN}

called $F_{1}$. From the fact that the character tallness appears in the cross-bred, to the exclusion of the opposite character, Mendel called it a dominant character; dwarfness, which disappears in the $\mathrm{F}_{1}$ plant, he called recessive.

The tall cross-bred was then allowed to bear seeds by self-fertilisation, and these are the next generation, $F_{2}$. When grown up they prove to be mixed, many being tall, and some being short, like their grandparents. Upon counting the numbers of this $F_{2}$ generation, it was discovered that the proportion of talls to shorts showed a certain constancy, averaging about 3 talls to $\mathrm{I}$ short, or 75 per cent. dominants to 25 per cent. recessives.

These $F_{2}$ plants were again allowed to fertilise themselves, and the offspring of each plant was separately sown. It was then found that the offspring $F_{3}$ of the recessives consisted entirely of recessives, and further generations bred from these recessives again produced only recessives, therefore they are proved to be true to the recessive character of dwarfness.

But the tall $\mathrm{F}_{2}$ dominants, when tested by a study of their offspring $\left(\mathrm{F}_{3}\right)$, instead of being all alike, as were the dwarfs or recessives, prove to be of two kinds, viz.: (I) Plants which give a mixed $\mathrm{F}_{3}$, consisting of both talls and dwarfs, the proportion showing again an average of 3 talls to I dwarf.

(2) Plants which give talls only, and are thus pure to tallness.

The ratio of the first to the second was as 2 to $\mathrm{I}$.

In his original paper on plant breeding, Mendel states that at the very outset he paid special attention to the family Leguminose, on account of their 
peculiar floral structure, and of this family the genus $P$ isum were found to possess in the best manner the necessary qualifications.

It is very unlikely that a disturbance through foreign pollen can occur in these flowers, as the fertilising organs are closely packed inside the keel, and the anther bursts within the bud, so that the stigma becomes covered with pollen before ever the flower is open.

Artificial fertilisation becomes, therefore, rather an elaborate process, but it nearly always succeeds. To perform the operation, the bud should be opened before it is properly developed, the keel is removed, and each stamen carefully extracted by means of a pair of forceps, after which the stigma can at once be dusted over with the foreign pollen.

The Mendelian discoveries have made matters very much easier for gardeners and florists in the work of plant breeding and fixing new varieties, as, according to Mendel's law, after three flowerings, the variety should be "fixed," whereas in the old, rather muddled way of doing things it often took double, and even treble that time, to fix a variety with any hope of it remaining constant.

If, after three flowerings, dominants only are produced, then the plant is pure; but if both dominants and recessives, then it is hybrid.

Among plants there are many hybrid instances, notably some pedigree strains of Primula sinensis, raised by Suttons. One is a large-flowered type, known as "Giant Lavender," having a pale magenta flower. This never comes true from seed, throwing always a number of bright magenta reds and a corre- 


\section{I4 THE GLORY OF THE GARDEN}

sponding number of whites, more or less tinged with magenta, which evidently exhibit the two gametic elements that must be combined in one zygote in order to produce the lavender. In this case, the bright magenta reds immediately breed true when self-fertilised.

There is another colour in Primula sinensis which apparently cannot exist in a pure form. This is a peculiar shade of "crushed strawberry," and the two pure forms by the union of which it is formed are the deep crimson of "Crimson King" and the white with a bright pink eye, brought out by Suttons under the name of "Duchess." By crossing these two together, the peculiar heterozygous colour can at once be produced.

One of the most striking instances of hybrid characters in the animal world may be seen in the case of the Andalusian fowl. The blue Andalusian fowl owes its popularity with the public, and its interest to the student of heredity, to its colour, which is a slaty blue-grey.

If two birds of this strain are mated, it will be found that they do not breed true. In every four birds on the average, three types of colour are produced: two blue, one black, and one white. The blacks are found to breed true to their colour and so are the whites, and the blue Andalusians, when mated together, again produce these three types in the same proportions.

From this it would seem pretty obvious that the blue Andalusian is a hybrid, and as such can never be fixed. But cross one of these black birds with a white and the result is a blue Andalusian, and blue birds obtained in this way produce a generation of 
fowls consisting of about one black, two blues, and one white in every four.

But though these examples of unfixable hybrids are not rare, they are in a minority, and, speaking generally, we can be fairly certain that a given type can be made to breed true, and to perpetuate its good qualities indefinitely.

From Mendelian discovery the practical plant breeder learns two lessons:

Firstly, that he must not discard the $\mathrm{F}_{1}$ generation, simply because it does not give him what he wants. It may be quite uninteresting from the horticultural point of view, exhibiting some oldfashioned or reversionary type, which is reproduced because all the factors which constitute it, happen to have been brought together in one individual.

But from the appearance of this first generation no guess can be made as to the properties of $F_{2}$ (the second generation). A great deal of valuable material has often been discarded by practical horticulturists, simply through ignorance of the Mendelian principles. The uninteresting types produced through crossing, though no improvement on the old and familiar varieties, would, if their seed had been saved, probably have given many novelties in the next generation.

Secondly, and this practical lesson is, if anything, more important: each individual plant must be bred from separately. For the Mendelian discovery does away with the old delusion that time and continued selection are needed in order to make a variety breed true. Purity of type depends on the meeting of two gametes bearing similar factors, and when two similarly-constituted gametes 


\section{I6 THE GLORY OF THE GARDEN}

do thus meet in fertilisation, the product of their union is pure, thus showing that the belief, held for so long, that purity of type depends on continued selection has no physiological foundation. For the homozygous individuals, which are the only ones that will breed true, may appear in $\mathrm{F}_{2}$. It is the business of the breeder to find these individuals, and by continued selection, he may perhaps succeed in the end, for at each selection he increases his chance of finding them; but by following the Mendelian method he can go straight to the point, and thus, very probably, save himself many years' work.

\section{Technical Methods.}

The actual work of crossing plants together is quite simple, but at the same time it demands much patience and concentration.

In the first place, the anthers of the plant to be used as a female must be picked out carefully with forceps before they are ripe. The flower is then covered to exclude insect visitors.

Muslin bags may be used for this purpose, but they are not so safe as rainproof bags made of parchment paper. The bag is put over the flower, the mouth being crushed up so as to fit the stem, and it is fixed in place with a thin piece of copper wire. Bees will often visit flowers covered over with muslin, and it is difficult to prevent this. The flower from which pollen is to be taken must also be covered before it opens, in order to keep its pollen pure and unadulterated.

The old-fashioned method of using a brush for the transference of the pollen is not advisable; it is 
very difficult to be certain that the brush is quite free from all foreign bodies.

The best plan is to pick out with fine forceps an anther from the flower to be used as the male, and with it to touch the stigma of the female flower.

The fingers and forceps should be continually cleansed with spirit, in order to kill any pollen grains that may adhere to them. By not paying strict attention to these little details, it is so very easy to spoil the results of several months of careful and laborious work.

"Nature, which governs the whole, will soon change all things which thou seest, and out of their substance will make other things, and again other things from the substance of them, in order that the world may be ever new."-Marcus Aurelius. 


\section{CHAPTER III}

\section{A DAY IN THE LIFE OF A PLANT}

"Wherever flowers cannot be reared, there man cannot live." NAPOLEON I.

How many people, even among those who care for their gardens and flowers, really take the trouble to enquire into the actual " inner workings" of the plant? By the great majority of people Botany is looked upon as a "dry-as-dust" subject, just a long list of classifications, Latin names of the families and natural orders, and so on. This is largely due to the wrong method of teaching Botany in the past; it is surely a great mistake to begin at that uninteresting end of the subject. The classifications are most necessary, but, of course, they are wearisome to the child or student (as the case may be) who knows nothing at all of the wonderful workings of the plant.

"Botany is the science which endeavours to answer every reasonable question about plants": begin your instructions at that end, explaining something about the physiology and work of the plants generally. Then this "dry-as-dust" subject will seem like a wondrous fairy-tale, as mysterious, even in these matter-of-fact days, as were any of the "Arabian Nights" stories.

The Root had better be our first consideration; and the office and work of the main root is to support 
the plant firmly in the ground, and to convey the food collected by the root hairs up to the stem and leaves. The extreme tips of all the roots are provided with a cap, formed of a mass of dead and dying cells, and the meaning of this cap is to protect the tender point of the root as it forces its way through the soil.

It is highly important for the gardener to know and realise that it is not the large, woody roots that absorb food from the soil, but the fine root hairs. For instance, if a gardener plants a rose, or a fruit tree, with only a few large roots, such a plant or tree cannot get any nourishment from the soil, until it has had time to make new root hairs to collect the food; therefore, until this has happened, the tree is in great danger of starving and dying. The root hairs emit a dissolving fluid which prepares the food for absorption, and it is only when there are plenty of healthy root hairs, able to carry out this function, that plants can obtain their food from the soil.

This is the reason for being so very careful, in moving plants, always to transplant with a good ball of soil, then the root hairs are less likely to be injured, and there is much less check to the tree.

The raw food, absorbed by the roots, is conveyed through the wood fibre and vessels of the stem, right up to the leaves, where, under the action of sunlight, it is manufactured into the finished material, which is then again conducted back through the sieve tubes of the stem to form new tissues, new shoots, and new roots. The protoplasm of the cells acts as a kind of magnet, drawing the liquid food from cell to cell as it is required. 


\section{THE GLORY OF THE GARDEN}

The pressure of the ascending sap is often very great. When active growth begins the cells become charged with liquid, and the pressure of one turgid cell on another forces the sap onwards. The best example of this force of ascending sap can be seen in the case of a bleeding vine. If the pruning of the vine is delayed until too late in the spring, moisture will ooze out freely from the cut surface of the stem, and the vine is then said to "bleed."

Naturally, this weakens the future growth of the vine very considerably, as, the cells having been cut through, the sap escapes easily, the quantity increasing as time goes on.

The Work of the Stem.-This may be described principally as "transport work." The stem conveys, by means of its vascular bundles and tissues, food to the branches and leaves. And it reconveys the elaborated food to those parts of the plant that need to be increased in size.

There is a continuous and definite system of flow and return of food-stuffs always going on in the stem, and specialised cells are concerned in that work.

Stems vary, of course, according to the species of plant under consideration; some are of annual duration only, and others live for an indefinite period. In the first case, the structure is of less permanent or woody a nature than in that of the second.

But in all stems, whether of trees or of annual plants, there is this transport work going on, a definite conveyance of food-stuffs backwards and forwards.

The Work of the Leaves. - These may be described as the workshops of the plant, wherein all the raw 


\section{A DAY IN THE LIFE OF A PLANT 2I}

material collected by the roots from the soil and air, are manufactured into the finished products required for building up the structure of the plant.

The green colouring matter in the leaf consists of chlorophyll grains, and these grains are capable of moving about at will in the cells; thus, in darkness, they range themselves round the wall of the cell, and in dull weather round three sides of the cell only.

The under surfaces of the leaf are furnished with breathing pores, called stomata. As many as 100,000 of these pores occur on every square inch of leaf surface; they permit of the transpiration of superfluous moisture, and of the absorption of carbon dioxide gas $\left(\mathrm{CO}_{2}\right)$.

They really act as safety valves to the cells, opening when there is a superabundance of water, and closing again when there is a shortage of moisture, so as to prevent the cells being emptied of their contents.

Some plants have their epidermis, or outer skin, covered with hairs, and these hairs have a special office to perform. On cold, windy days, or in very dry weather, they lie close over the stomata, to prevent transpiration, and also to keep a layer of warm air over the epidermis.

The health of the plant depends largely on the working of these stomata, and that is one reason why plants in towns and cities often fail to thrive, because the stomata become choked with soot and dust. This should show us a very practical application to gardening, pointing out how very necessary it is to keep the leaves clean and healthy, that they may breathe properly, and carry on without 
hindrance the wonderful work of food manufacture.

The daily work and routine of this green part of the plant is one of the most interesting phenomena in nature, and yet by the greater number of people, one of the least-thought-of facts. It is, of course, a commonplace piece of knowledge that plants do exactly the opposite thing to the atmosphere, to that done by human beings and animals-viz., they purify the air during the daytime by breathing out pure oxygen and taking in the carbon dioxide from the surrounding air. This gas, whose chemical formula is $\mathrm{CO}_{2}$, is at once seized upon by the chlorophyll grains, or chloroplasts (the green colouring matter of the plant), and " assimilated."

After entering into the cells of the leaf, the $\mathrm{CO}_{2}$, together with a certain amount of water, undergoes a chemical change, which results in the formation of a soluble carbohydrate.

The word Carbohydrate simply means a substance composed of carbon, hydrogen, and oxygen. Starch and sugar are carbohydrates, and the first to be formed after this "carbon-fixation" is sugar, probably cane sugar, which is in soluble form, and in this form the leaves send it along by special cells and vessels down to the stem and roots.

The next process that this sugar undergoes is to be converted into starch grains, which latter, being solid, are more easily compressed into a small space. Normally, the night-time storage form is sugar, and each morning, directly it is light, the protoplasm seizes on the sugar, elaborates it, and once more converts it into starch for the daytime storage form. 
There are still a few old-fashioned countryfolk who believe in always cutting their cabbages and lettuces either last thing at night or else at dawn in the very early morning.

They will tell you that they are more crisp and tender before the sun is on them. This is quite true, and it is a fact that they are also sweeter, and when the physiology of the plant is studied then light breaks in, and a reason dawns for what would otherwise appear to be mere superstition.

We turn the light of science on these " old-wives" fables" and smile no longer, for we find that in spite of some superstition and legendary magic, much of the solid gold of truth remains.

This work of seizing upon a raw gas and converting it into food can only be performed by plants; no part of an animal or human being can perform these functions; it is a special prerogative of plant life.

Day and night there is always some useful work going on in some part of the plant, with never a complaint, all done silently and quickly, with no words, no fuss, and no bother.

During the night-time the green part of the plant performs an exactly opposite process to that of the day. During the day it breathes out oxygen and takes in $\mathrm{CO}_{2}$, but at night-time this process is reversed, and the plant breathes after the manner of human beings, taking in oxygen and giving out $\mathrm{CO}_{2}$.

Therefore, on account of this, some people say, and firmly believe, that it is most unhealthy to sleep with a plant or flowers in one's room. But as it would take pretty well a whole conservatory of 
plants to breathe out as much $\mathrm{CO}_{2}$ as is emitted by one human being, surely a few plants or flowers are not such dangerous room-mates as one human being !

Scientists tell us that, if it were not for the fact of plants purifying the atmosphere by breathing in the poisonous $\mathrm{CO}_{2}$ and giving out fresh oxygen, the earth would soon be quite uninhabitable; we should have such a superabundance of impure gases hanging on the air unused, and to us unusable without the aid of plants, that we should shortly be poisoned with these gases, and the earth would become a dead planet.

The Fall of the Leaf.-In very hot countries trees retain most of their leaves all the year round; a leaf falls occasionally, but no considerable portion of them drop at any one time. This holds good with regard to our own pine, fir, and spruce trees. The impossibility of absorbing moisture from the soil when the ground is very cold and near freezingpoint would cause the death by drying up of trees with broad leaf surfaces. Also, in countries where there is much snow, most large-leaved trees could not escape injury to their branches from overloading with snow. For these reasons most of our forest trees are deciduous-that is, they shed their leaves at the approach of winter, and the tree remains in a dormant condition.

In the autumn the green pigment in the leaf breaks up, leaving behind yellow granules, and these produce the autumn colour. This brilliant colouration of autumn leaves is often quite wrongly supposed to be due to the action of frost.

But it depends merely on the changes in the 
chlorophyll grains and the liquid cell contents. This is what happens in the autumn: When the green pigment or colouring matter breaks up and leaves behind the yellow granules, then many of the materials in the leaf, including starch, gradually recede along the leaf-stalks into the twigs, and here they stay, and are ready for use in the following spring.

But in the oak and beech this process does not go on so extensively as in most other trees; the food materials do not recede from the leaves before they fall, and that is why their leaves are so much richer and more valuable as fertilisers.

Gardeners always prefer leaf soil which is composed of oak and beech leaves in preference to that of any other tree, as experience shows them that these leaves give the best results.

All these instances should show very clearly the need there is for a close union between horticulture and botany. Every gardener should be something of a botanist, and try to learn a little of the structure, anatomy, and physiology of the plant; otherwise he is working in the dark, and cannot feel the same interest in all the little details of ordinary, everyday gardening. One is continually coming across little gems of scientific knowledge that help very materially in the cultivation of plants and their successful treatment.

There is any amount of 1esearch work waiting to be done in the gardening world, and plenty of unexplored fields await our efforts, in the raising of new varieties and improving existing ones, both in the fruit and vegetable kingdom, to say nothing of the flowers. 


\section{THE GLORY OF THE GARDEN}

Then there is much work still to be done in the eradication of fungoid and insect pests that attack our crops-perfection is very far distant in that direction.

Let us get away from that antiquated idea that to take up gardening means to give up all brain work. We want to get beyond the famous "Punch" caricature of a gardener-a drearylooking creature, clay pipe in his mouth, corduroy trousers tied below the knee with a bit of string, and a face devoid of any intelligence, because, it was said: "Any fool can work on the land."

Let us rather take as our motto Maartens' famous saying:

"Gardeners have rare opportunities of thinking, Watching how queer things grow." 


\section{CHAPTER IV}

\section{HERBS AND THEIR ORIGIN}

\section{"Excellent Herbs had our fathers of old, \\ Excellent Herbs to ease their pain; \\ Alexanders and Marigolds, \\ Eyebright, Orris and Elecampane, \\ Basil, Rocket, Valerian, Rue \\ (Almost singing themselves they run), \\ Vervain, Dittany, Call-me-to-you, \\ Cowslip, Melilot, Rose-of-the-sun; \\ Anything green that grew out of the mould \\ Was an excellent Herb to our fathers of old."}

Rudyard Kipling.

IN gardening, almost more than in any other art or craft, the past and the present are linked together, and although people in these days are much amused at the old superstitions of the herbalists, regarding the faith that they placed in the healing virtues of our wild flowers, yet modern research has justified that faith. For we find that in spite of its alloy with magic, astrology, and superstition, much of the solid gold of truth remains.

The Doctrine of Signatures, as it was called, was firmly believed in by the old herbalists. The idea was, that by the mercy of God, many of the herbs that $\mathrm{He}$ made for the service of men, were stamped, as it were, and signed with their characters, so that they could be read at a glance.

One of the chief exponents of this theory was Paracelsus, or to give him his full name, Philippus 
Aureolus Theophrastus Bombastus, of Hohenheim. He lived from 1493-I 54I, and was a doctor, but not a favourite with his fellow-men, owing to his almost incredible boastfulness. The word "bombast" was in all probability coined from his name.

At the same time, although he was something of a quack, his writings are occasionally illumined with real scientific insight, and certainly he infused new life into the chemistry and botany of his day. For an understanding of this doctrine of signatures, it may be enlightening to quote from Paracelsus himself: "I have ofttimes declared, how by the outward shapes and qualities of things, we may know their inward virtues, which God hath put in them for the use of man. So in St. John's Wort we may take notice of the leaves, the porosity of the leaves, the veins-(I) The porosity or holes in the leaves signifies to us that this herb helps inward or outward holes or cuts in the skin. (2) The flowers of St. John's Wort, when they are putrified, they are like blood; which teaches us that this herb is good for wounds, to close them and fill them up."

An Italian, of the name of Porta, developed this theory still further, and often, it must be confessed, he soared very much into the realms of fancy. $\mathrm{He}$ held that herbs with a yellow sap would cure jaundice, whilst those whose surface was rough to the touch, would heal those diseases that destroy the natural smoothness of the skin. The resemblance of certain plants to certain animals opens up to Porta a vast field of conjecture and romancing. Plants with flowers shaped like butterflies would cure the bites of insects, while those whose roots 
or fruits had a jointed appearance, and thus remotely suggested a scorpion, were sure remedies for the bites of serpents.

William Cole, an Englishman, in 1657 , did much work in furthering this doctrine of plant signatures. $\mathrm{He}$ seems to have possessed a philosophic mind, and to have been much troubled because a large proportion of the plants with undoubted medicinal virtues, had no obvious signature. However, he got over this difficulty by concluding that a certain number were endowed with signatures, in order to set man on the right track in his search for herbal remedies; the remainder were purposely left blank, in order to encourage his skill and resource in discovering their properties for himself. A further ingenious argument is, that a number of plants are left without signatures because, if all were signed, " the rarity of it, which is the delight, would be taken away by too much harping upon one string."

Another strong supporter in this country of the doctrine of signatures was the astrological botanist, Robert Turner. He states that God has imprinted upon the plants, herbs, and flowers, as it were in hieroglyphics, the very signature of their virtue.

"In physic by some signature, Nature herself doth point a cure."

In 1644 , Robert Turner wrote: " For what climate soever is subject to any particular disease, in the same place there grows a cure."

This point of view deserves our gratitude, as it led to Dr. Maclagan's discovery of salicin as a cure for rheumatism. On the ground that in the case of malarial disease "the poisons which cause them 


\section{THE GLORY OF THE GARDEN}

and the remedy which cures them are naturally produced under similar climatic conditions," Maclagan sought and found in the bark of the willow, which inhabits low-lying, damp situations, this drug, which has proved so valuable in the treatment of rheumatism.

Paracelsus was full of botanical mysticism, and was a firm believer in the influence of the heavenly bodies upon the vegetable world, or, in other words, in botanical astrology.

$\mathrm{He}$ considered that each plant was under the influence of some particular star, and that it was this influence which drew the plant out of the earth when the seed germinated. He held each plant to be a terrestrial star, and each star a spiritualised plant.

This subject of botanical astrology will be more fully dealt with in Chapter X.

The Doctrine of Signatures explains the popular names of many of our berbs:

Clary, or Clear Eyes, being most useful in all eye troubles.

Prunella, or Self-Heal, acting as a magic balm on all cuts or bruises.

Gout Weed, so called on account of its efficacy in all gouty afflictions.

Feverfew, being a most soothing and calming herb in all feverish diseases.

Foxglove leaves are of great value, yielding the drug digitalin, a very old remedy in heart trouble.

An extract made from Dandelion roots is used in liver tonics. 
In Deadly Nightshade both root and leaves are used; their medicinal value is for the relief of pain in rheumatic diseases, and also by oculists for the dilation of the pupil of the eye.

Viper's Bugloss has its stem speckled like a snake, pointing out to all that it could cure snake bites and the stings of scorpions. In spite of its pretty forget-me-not-blue flowers, the plant has a viperish look, which makes it very distinctive.

Pulmonaria, or Lung Wort, has broadish leaves, spotted in a manner resembling the lungs of men and animals. It was esteemed useful in all chest and lung complaints.

The Heart Trefoil has heart-shaped leaves, which are sometimes bloodstained, so this herb protects the heart.

$T$ he leaves of the St. Fobn's Wort look as if they were perforated with tiny holes, like the pores of the skin, so here we have a herb that cures cuts and abrasions. This herb is indeed one of the most magical of plants, as evil spirits positively shudder at it, flying off at the first whiff of its scent.

There are many legends woven about the St. John's Wort, and one of them tells us that if after sunset on St. John's Eve you happen to step on the plant, a fairy horse arises out of the ground which will carry you gloriously all the night, to leave you wherever you may happen to be when the first ray of the rising sun stirs the world.

There may be more in these cures of Nature than people of late years have been willing to 


\section{2 \\ THE GLORY OF THE GARDEN}

allow; remedies are not necessarily so much more effective for being done up with all the chemist's skill and cunning of white paper, scarlet sealing-wax, and pink string. These are attractive, no doubt, and aids to faith (which is half the battle); but supposing that customary and orthodox medicines happened to be out of reach, it might be very useful indeed to possess some old-time knowledge of the herbal remedies of our forefathers. Some people are inclined to raise objections on the score that herbalism is a quack or empirical system of medicine unworthy of support or serious consideration. They believe it to be a mere tissue of "old wives' lore" and silly superstition, and are probably not aware that modern pharmaceutical research has vindicated the reputation of many an old-fashioned "simple," and has winnowed herbalism of its ignorant elements, raising the practice of herbal pharmacy to a scientific element.

How did the herbal ideas of bealing arise? Simply by watching the self-cure of animals, whose instinct led them to the plants with healing properties for various complaints.

An interesting old superstition centres round the Goat, from which we learn that he was supposed to be the "Herbalist Quadruped," clever in finding herbs that were good for physic.

In the Middle Ages every monastery and convent had its physic garden, and it is to the untiring skill and energy of the monks that we owe much of our knowledge of medicinal plants and their uses. The monks were, indeed, the grand pioneers of gardening in all its branches, and we owe them a very large debt for their skill and practice in these matters. 
In olden days the berb Rue was brought into court to protect the Judge and Bench from the contagion of gaol fever, and it was probably quite effective, though nobody knew the reason. Recent research has shown that the essential oil contained in rue, as in other aromatic herbs like elecampane, rosemary, and cinnamon, serves by its germicidal principles to extinguish bacterial life. Nobody knew much about bacteria in the time of Elizabeth Fry, nor was much known about the alkaloids contained in plant tissues prior to the discovery of "opium salt," or morphine, by Derosne in 1803 . Yet rue had been disinfecting stuffy law courts, and poppies had been acting as soporifics, long before the action of either came to be explained.

According to old beliefs, one of the most useful plants to grow in one's garden is the Camomile, regarded as the plants' physician. Nothing was thought to keep a garden so healthy, and it was even said to revive drooping and sickly plants if brought near them.

Saffron was used very extensively for dyeing, in fact so much so that Henry VIII. issued a royal proclamation strictly forbidding its use for hairdyeing purposes. Bacon says of saffron that it conveys medicine to the heart, cures its palpitation, removes melancholy and uneasiness, revives the brain, renders the mind cheerful, and generates boldness. Rather many virtues for one small plant to claim !

For any meek and gentle souls who may wish to cultivate ferocity for the time being, it may be useful to them to know that the root of Cat Mint, when chewed, will make the most quiet and gentle 


\section{4 \\ THE GLORY OF THE GARDEN}

person fierce and quarrelsome. There is a legend of a hangman who could never bring himself to perform his office until he had partaken of this herb. Cats are most astonishingly fond of the plant, ard will seldom fail to dig up a newly-planted specimen if they chance to come across it, from which fact sprang the couplet:

"If you set it, the cats will get it;

If you sow it, the cats won't know it."

Rats, on the other hand, have a great and shuddering aversion for the cat mint, and will go nowhere near it. Corn Mint has quite a different use, as it was said to prevent milk from curdling, and that the milk of cows who fed on this herb could not be turned into cheese.

Fennel seems to have served many purposes, and to be the worker of many good deeds.

In the time of Edward I. we read that the poor ate it when hungry and it satisfied them, the fat ate it to make themselves thin, and the blind to restore their sight.

"Above the lowly plant it towers,

The Fennel with its yellow flowers,

- And in an earlier age than ours,

Was gifted with the wondrous powers

Lost vision to restore."

Dill was of old a very favourite herb for use in magic:

"Here holy Vervain and here Dill,

'Gainst witchcraft much availing."

Pennyroyal was another herb with equally good virtues, as it was said to counteract the evil eye. 
Pliny tells us that a chaplet of pennyroyal worn on the head, is the best cure for headache and giddiness.

Wormwood is, with the exception of rue, the bitterest herb known; but everyone must regard it with interest, because of its responsibility for the world-famous absinthe.

In France, acres of wormwood are grown simply for the purpose of making absinthe; the leaves, eaten raw, are said to be very wholesome.

Tansy was used in the old days for cakes and puddings, in spite of the fact that tansy undoubtedly ranks as one of the "bitter" herbs. It appears that tansy cakes were eaten more especially at Easter-time, as some writers tell us, to correct the ill-effects of a prolonged fish diet. We have the support of an old Easter carol for this belief:

"Soone at Easter cometh Alleluya,

With butter, cheese, and a Tansy."

The Verbena, or Vervain, was the Herba Sacra, said by the Romans to cure bites from animals, arrest venom, and act as an antidote to many poisons; and feasts called "Verbanalia" were held annually in its honour. Then legend catches up the thought, and tells us how the herb was first found on Calvary, and staunched the wounds of Christ.

"Hallowed be thou, Vervain, As thou growest on the ground,

For in the Mount of Calvary

There thou wast first found."

The Spikenard of Scripture is made from a valerian that grows in the Himalayan Ranges. The medicinal 


\section{THE GLORY OF THE GARDEN}

properties of valerian have been well known through all the ages; cats delight in it to such an extent that they will go perfectly wild over it at times, gnawing at the roots, and trying to tear up the whole plant.

Rosemary is a plant of many virtues, and in olden times no garden was considered worthy of the name which did not include this inestimable herb. It was enormously in request for making wine, physic, and scent, and up till the present time it is one of the ingredients of Eau-de-Cologne. The flowers are well beloved by the bees, making most excellent honey.

Bergamot is another great favourite with the bees; in fact, its old-fashioned name is "Bee-Balm," surely sufficient to prejudice anyone in its favour! The flowers are a warm crimson, and make a glorious patch of colour in the garden. Oil of bergamot goes into perfumery, and an extract from the leaves helps to compose the preparation known to modern doctors as thymol.

Pimpernel, in the olden days, was a sure remedy for the bite of a mad dog, and also an effective remover of all sadness. It is very interesting to note that the pimpernel should have won this character for cheerfulness amongst the English, for the name in the Greek means to laugh.

Fumitory is another of the herbs with a magic past, as its very name will tell us, for many of the old books say that when burned, the smoke was used in sorcery. Others again say that instead of growing from seed, it is produced from vapours rising from the earth. Truly a plant to connect with the witch, her cauldron, and her black cat! 


\section{HERBS AND THEIR ORIGIN}

'In every plant

There lives a spirit, more or less akin

Unto the spirit of humanity.

Some heal diseases dire; others wake

Strange whimsies in the busy brain of man."

\section{Scent in the Garden.}

Its Esthetic and Practical Uses.-In olden days no garden was considered complete without its borders of sweet-scented flowers and herbs, and it seems that a great deal more attention was paid to that fragrant subject than is the case in these days.

Too often individual flowers are "over-cultivated" to produce blossoms of colossal size or striking and dazzling colours, and the delicate beauty of fragrance is eliminated.

Some of the newer roses are a typical case in point: they are floral wonders in every sense of the word except that of scent, and that intangible and subtle delight seems totally lacking in these otherwise perfect flowers.

Modern research has proved that our forefathers were quite right in their cultivation of flowers and plants for scent; they were not merely luxuriously delighting their senses, as science has now disclosed to us that ozone is developed when the sun shines on most kinds of fragrant plants, such as fir and pine trees, scented flowers, and sweet herbs generally.

John Evelyn, that wise and famous gardener of old, had very ambitious ideas, as he soberly and solemnly proposed to make London the healthiest, as well as the happiest city in the world, by sur- 


\section{THE GLORY OF THE GARDEN}

rounding it with plots and hedgerows of sweetbriar, jasmine, lilies, rosemary, lavender, musk, and marjoram.

But, unfortunately, he was not able to carry out his ideas, so we have not been able to see the results of such a truly alluring scheme.

To quote an old-world opinion on scent: "Thyme will renew the spirits and vital energy in long walks under an August sun; the Maréchal Niel rose is invigorating in lowness of mind or body. Sweetbriar promotes cheerfulness; yellow bedstraw, cowslip, wallflower, damask and pink china roses, plum blossom, bog myrtle, and wild honeysuckle refresh the spirits; while the smell of ground ivy, charlock, woodruff, rosemary, and fresh-cut grass will often prove a bodily refreshment."

These views should not surprise us, as, considering how large a part the visible plays in our enjoyment of gardens, it is not therefore very astonishing that much of their charm should also depend upon the invisible.

For it always seems that there is something even more wonderful and subtle about the unseen gift of fragrance, than about the more striking gift of colour; scent is less definable, less explainable, and its wonders have been less explored.

In the herb garden, fragrance depends more on the leaves of plants than the flowers, and one secret is soon discovered: the value of leaf scents. Flower scents are evanescent, leaf odours are permanent. On the other hand, leaf odours, though "ready when sought," do not force themselves upon us, as it were, like flower scents, which we 


\section{HERBS AND THEIR ORIGIN}

must smell whether we will or no. The leaf scents have to be coaxed out by touching, bruising, or pressing, but there they are, all the time.

\section{HERBULARIS}

"A chaplet then of Herbs I'll make

Than which though yours be braver,

Yet this of mine I'll undertake

Shall not be short of savour:

With Basil then I will begin,

Whose scent is wondrous pleasing;

This Eglantine I'll next put in,

The sense with sweetness seizing;

Then in my Lavender I lay,

Muscado put among it,

With here and there a leaf of Bay,

Which still shall run along it.

"Germander, Marjoram and Thyme,

Which usèd are for strewing;

With Hyssop as an Herb most prime

Here in my breath bestowing;

Then Balm and Mint help to make up

My Chaplet, and for trial

Cost Mary that so likes the cup,

And next it Pennyroyal.

Then Burnet shall bear up with this,

Whose leaf I greatly fancy;

Some Chamomile does not amiss

With Savoury and some Tansy.

“Then here and there I'll put a sprig

Of Rosemary into it,

Thus not too little nor too big,

'Tis done if I can do it."

Michael Drayton. 


\section{CHAPTER V}

\section{THE PATRON SAINTS OF GARDENING}

"Comes my spade. There is no ancient gentlemen but gardeners, ditchers, and grave-makers; they hold up Adam's profession."-Shakespeare: Hamlet.

WiтH all the myth and legend interwoven with gardening, it is only fitting that gardeners should have a patron saint to guard their interests and look after their welfare, and in this matter they are particularly lucky, having two saints as their especial patrons: St. Fiacre and St. Phocas.

All through the ages we owe far more than we know or imagine to those grand pioneers the monks, for their skill in flower culture and herbalism; and gardeners, who, to a man, are dedicated to such a peaceful and meditative pursuit, should care to know of the story of St. Fiacre, the Irish prince, who turned hermit, and after his death was hailed the patron of gardeners, and of St. Phocas, the holy gardener who was martyred for the Faith in early days.

The lives of these holy men should prove of great inspiration to all tillers of the soil in these very mundane days, and true gardeners, being simpleminded folk, will want none of the " New Thought" of these modern days. The old religion and the same patron saints of a few centuries ago will doubtless be quite good enough for them. 


\section{THE PATRON SAINTS OF GARDENING 4I}

St. Fiacre was by birth an Irishman, and, tradition tells us, nobly born, probably a prince. But he left Ireland with some companions in quest of solitude, at that time when missionary zeal was sending Irish monks all over Europe to convert many to the Faith.

Fiacre made his vows at a new monastery which St. Faro, Bishop of Meaux, had founded on the River Marne, the Monastery of St. Croix.

But even in this holy life of strict rule and austerity, St. Fiacre craved still greater solitude, so he went to the holy Bishop, and told him of his desire to become a hermit, and the Bishop, being a good and saintly man himself, read the right intention in Fiacre's heart, and gave him a solitary dwelling in a forest.

There Fiacre soon cleared a space and built a small oratory in honour of Our Lady, and a hut close by, where he slept. Then, this done, he began to make his garden.

St. Fiacre must have thought that here in the forest, in the midst of his garden, he was safe from the world, and yet he became known. Possibly some swineherd or shepherd whom the saint had befriended, went forth on his way and spread news of this holy man who had made the wilderness to blossom as a rose. So the news filtered through the country, and the people came to see this wonder; but when they had heard the holy man preach and seen him heal the sick, they were convinced of his sanctity, and knew that this was no magician, but a saint of God.

Finally the saint was obliged to build another hut to accommodate those who came from afar to consult 


\section{$4^{2}$ \\ THE GLORY OF THE GARDEN}

him, and so he went to the Bishop and asked him for more land. The Bishop, it must be remembered, was himself a saint, and he granted Fiacre's request in a curious way. He gave to him as much land as he could enclose with his spade in one day.

So our holy gardener hurried back to the forest, and marked out a space larger than any dozen men could clear in one day, and then, after going to his oratory to pray for help, he set to work.

Well, there were people watching him from various parts, and before very long a deputation went off in hot haste to fetch the Bishop: a miracle was happening, for far and wide, wherever the eye could reach, there were angels at work felling the trees, clearing the ground, and others again were busy with spades digging. By sunset the space was all cleared.

And so, by this miracle of enlarging the space of his garden, this saint has rightly become the patron saint of gardeners. He died about the year 670, and his feast is observed on August 30 .

There seems no authentic reason for St. Fiacre also being known as the patron saint of cab-drivers. It arose through one man, who let out carriages for hire, placing a statue of St. Fiacre over his doorway, and all the coaches starting from this point began to be called "fiacres," and the drivers placed images of him on their carriages and hailed him as their patron.

On the site of St. Fiacre's cell a large Benedictine Priory was built, and here his relics were kept and did many wonders of healing. 
The Legend of St. Phocas, Patron of GardenERS AND SAILORS.

St. Phocas lived towards the end of the third century, near the gate of Sinope, a city of Pontus. He obtained his living by cultivating a garden, in which he grew flowers and vegetables; and, according to tradition, everything he grew flourished exceedingly, and was much more prolific than under other people's cultivation.

There is a statue of St. Phocas at St. Mark's, Venice, where he is portrayed as of a fine and muscular build, with a flowing beard, and dressed as a gardener, holding a spade.

Finally, he died for the Faith, being martyred during the Diocletian persecution in the year 303 .

It came to the ears of the heathen rulers that Phocas was a Christian, and lictors were at once sent out to search for and kill him. But they were unable to find his house, and came there all unknowingly for shelter, little guessing it was the house of Phocas. He gave them food and hospitality, as was his wont in the case of all strangers and wayfarers, and when he asked their errand, they said they were looking for one Phocas, a Christian, and begged his help. The holy Phocas invited them to rest there that night, promising to be their guide the next day. After they had gone to bed the saint went out and dug a grave for himself amongst his own beloved flowers, and then prepared his soul for death.

The morning came and the saint's guests were ready to depart, when he stayed them by saying they need go no further, as he was Phocas, for whom 


\section{THE GLORY OF THE GARDEN}

they were searching. The lictors were grieved and horrified at the idea of staining their hands with the blood of their host; nevertheless they obeyed their orders and severed his head from his body, thereby procuring for the holy man the martyr's crown.

Holy Church keeps his feast day on July 3 .

St. Phocas is also the special patron of sailors on the Black Sea and the Mediterranean, for he has often been seen at night, when the tempest arises, waking up the weary steersman at the rudder, and at other times minding the cable and sails, or at the prow looking ahead for the shallows.

Therefore it became a custom with sailors to have Phocas for their guest, and day by day they set aside a portion of each meal for the martyr, nor would they touch it till they had laid by the small coin that was its equivalent. Then, at the end of the voyage, they would distribute among the poor the sum thus collected.

\section{St. Benedict and the Bees.}

In common with many other legends, that of St. Benedict seems to have been tucked away so tidily in a back compartment, in England, that it has been entirely forgotten by most people.

Tradition tells us that St. Benedict takes a special interest in protecting people and animals against disease, and the holy saint was said to be particularly fond of bees.

In Brittany, there is hardly a hive of bees to be seen without its little blessed medallion hanging over the doorway, or " bee-way." 


\section{THE PATRON SAINTS OF GARDENING 45}

The average, practical, unromantic English person will say: "But the Breton peasant is, of course, quite uneducated and so superstitious." These hard-headed, material-minded ones would scorn to have recourse to some "mythical saint who lived in those unenlightened Middle Ages"!

Still, it is a beautiful act of faith on the part of these poor peasants of Brittany to hang "little Father St. Benedict" over their hives, saying every Tuesday (a day set apart particularly to his memory) five Paters in honour of the Passion of Our Lord, three Aves in honour of Our Lady, and three Glorias in honour of St. Benedict.

Then worry no more about the bees, but leave them to the good saint; he will look after them and see that no disease touches them.

The bees, being very psychic, are quite aware of the blessed medallion hanging over their doorway, and they like to think that a great saint in heaven is looking after their interests; so on this score they will probably thrive all the better, even supposing that St. Benedict saw fit to do nothing special for them, which is not very likely.

"A Garden is a lovesome thing, God wot:

Rose plot,

Fringed pool,

Ferned grot.

The veriest school

Of peace; and yet the fool

Contends that God is not.

Not God! in gardens! When the eve is cool?

Nay, but I have a sign;

'Tis very sure God walks in mine."

THOMAS EDWARd BROWN. 


\section{CHAPTER VI}

\section{SOME BEE LORE}

"The swarthy bee is a buccaneer,

A burly velveted rover,

Who loves the booming wind in his ear,

As he sails the seas of clover.

"His flimsy sails abroad on the wind

Are shivered with fairy thunder;

On a line that sings to the light of his wings, He makes for the lands of wonder."

EVERy gardener should be a bee-keeper, and every garden should have its hive of bees, for in all matters of fruit culture it has been abundantly proved that we are absolutely dependent on the bees for our fruit crops. Everyone who grows fruit knows that there are some trees and bushes that may be furnished with a wealth of blossom which from some cause fails to set, and this failure is invariably attributed to frost or cold winds during the flowering period.

But it often happens that neither of these causes is responsible, and much investigation has been given to the subject of late years, both in this country and in America.

And the result of these observations shows us that the primary cause for fruit blossom failing to set, is very often due to the fact that some varieties bear self-sterile flowers, that is to say, flowers incapable of being fertilised with their own pollen. 
Thus, for example, if one grew Cox's Orange Pippin only, the probability is that, though the trees might flower profusely, few if any fruits would be formed, unless bees were plentiful in the district to convey the necessary pollen from other varieties. On the other hand, one might grow only Worcester Pearmain and secure abundant crops, as the flowers of this variety are capable of being fertilised with their own pollen.

Gooseberry and currant flowers are self-fertile, but cannot self-pollinate themselves, as their pollen grains are glutinous, so the agency of bees is required to transfer the pollen to the stigma.

Raspberries and loganberries do not fruit so freely if their flowers are not pollinated by the bees.

It can easily thus be seen how very dependent we are upon the bees for our fruit crops, and this being the case, surely we should endeavour to learn more of their life, and try to encourage bee-keeping on a much larger scale than is now practised in this country. True, of late years there has been a terrible scourge, the "Isle of Wight" disease, which has carried off many large stocks of bees completely, but now it almost seems that the plague has abated somewhat, and a great endeavour should be made to bring the lost art of bee-keeping back into all the country villages.

\section{The Origin of the Honey Bee.}

Amongst all the fables of ancient mythology, that dealing with the origin of the honey bee is without doubt one of the prettiest.

On the birth of Jupiter, his mother, Ops, entrusted 


\section{THE GLORY OF THE GARDEN}

him to the two daughters of the King of Greece, Melissa and Amalthea, in order that the young god might escape the fate that awaited him, that of providing a repast for his father, Saturn. To smother the cries of the unfortunate baby god, the sisters continually beat upon brazen pans, and this attracted the neighbouring wild bees, who forthwith undertook the responsibility of his nourishment, bringing him daily supplies of honey. In acknowledgment of their services, Jupiter endowed these wild bees with the power of parthenogenesis, so waiving the ordinary male and female principles; and entrusted their descendants with the work of gathering honey for the food of man.

The countryfolk of Scotland and Ireland, who seem to live in such close touch with Nature, still cling to the old custom of "telling the bees." This is a relic of the time when the honey bees were looked upon as the guardians of the household, and every important event in the family life, whether of joy, sorrow, or adventure, was told to them as a mark of courtesy and consideration.

"Bees, Bees! Haste to your bees.

Hide from your neighbours as much as you please,

But all that has happened to us you must tell,

Or else we will give you no honey to sell."

The old bee-fathers used to raise their hats to the honey bee, a gracious act of courtesy, the spirit of which we should do well to emulate.

It is an old and well-known fact that the honey bee is possessed of marvellous-one might almost say psychical-perceptions, and is extremely sensitive to conditions not merely material and physical, 
but mental and even moral, which we mortals cannot always appreciate.

Numerous cases are known of bees attacking people who, to all appearance, treated these relentless judges of mankind with due respect and consideration, but who have gone to their bees in anger or in a state of nervous excitement or exhaustion. Pliny solemnly cautions thieves and malefactors against approaching hives at any time, and Butler, a devoted student of bee life, living in the reign of Queen Anne, gives most elaborate advice as to the necessary qualities of the good bee-master.

With the ancient Romans, a flight of bees was considered a bad omen. Appian says a swarm of bees alighted on the altar and prognosticated the fatal issue of the battle of Pharsalia.

It is said that when Plato was in his cradle a swarm of bees alighted on his mouth.

In Christian art, St. Ambrose is represented with a beehive, as there is a similar tradition of a swarm of bees alighting on his mouth when he was an infant.

"Marriage, birth or burying, News across the seas, All you're sad or merry in, You must tell the bees. Tell 'em going in and out Where the Fanners fan, 'Cos the bees are just about As curious as a man.

"Don't you wait where trees are, Where the lightnings play, Nor don't you bate where bees are,

Or else they'll fly away, 
Pine away, dwine away,

Anything to leave you.

But if you never grieve your bees,

Your bees 'll never grieve you."

The greatest scientists and most devoted students of the wonderful bee commonwealth, all agree with Maeterlinck that- " Beyond the appreciable facts of their life we know but little of the bees, and the closer our acquaintance with them, the nearer is the appreciation of our ignorance brought to us."

This great bee lover, after many years of beekeeping, says: "You will find that we shall often halt before the unknown," and that we most certainly do, in that most wonderful and complex city known as the hive.

In his book "The Life of the Bee," Maeterlinck lifts the veil for us, and shows us the interior of a hive from the bees' point of view, as far as our limited human understanding can picture the world as it looks to them.

"Inside the hive, it would seem that from the height of a dome more colossal than that of St. Peter's at Rome, waxen walls descend to the ground, balanced in the void and the darkness.

"Each of these walls, whose substance is still immaculate and fragrant, of virgin, silvery freshness, contains thousands of cells, stored with provisions sufficient to feed the whole people for several weeks.

"Here, lodged in transparent cells, are the pollens, love ferments of every flower of the spring, making brilliant splashes of red and yellow, of black and mauve.

"Close by, sealed with a seal only to be broken 
in days of supreme distress, the honey of April is stored, most limpid and perfumed of all, in 20,000 reservoirs that form a long and magnificent embroidery of gold, whose borders hang stiff and rigid. Still lower, the honey of May matures, in great open vats, by whose side watchful cohorts maintain an incessant current of air. In the centre, and far from the light, whose diamond rays steal in through the only opening, in the warmest part of the hive, there stands the abode of the future, here does it sleep and wake. For this is the royal domain of the brood cells, set apart for the Queen and her acolytes, about 10,000 cells, wherein the eggs repose, 15,000 or 16,000 chambers tenanted by larvæ, 40,000 dwellings inhabited by white nymphs, to whom thousands of nurses minister.

"And finally, in the holy of holies of these parts, are the three, four, or six sealed palaces, vast in size compared with the others, where the adolescent princesses lie who await their hour; wrapped in a kind of shroud, all of them pale and motionless, and fed in the darkness."

It seems that of all the insect associations, there are none that have more excited the attention and admiration of mankind in every age, than the colonies of bees, and many ancient Greek and Roman writers are loud in their praise.

Marvellous and wonderful in their absurdity, were some of the errors and fables which many of the ancients believed, with regard to the generation and propagation of the "busy bee." For instance, that they were sometimes produced from the putrid bodies of oxen and lions, the kings and leaders from the brain, and the vulgar herd from the 


\section{2}

\section{THE GLORY OF THE GARDEN}

flesh. This fable was derived probably from swarms of bees having been observed, as in the case of Samson, to take possession of the dried carcasses of these animals; or possibly from the myriads of flies (for often the ignorant do not readily distinguish flies from bees) generated in the decaying flesh of dead animals.

This idea is particularly repulsive though, when suggested in connection with such a clean insect as a bee, for they cannot tolerate dirt in any shape or form. Their own hives are kept most scrupulously clean, and often they have been known to attack an unwashed specimen of humanity, who dares to come near their hives smelling of perspiration.

It is quite true, as Emerson tells us:

\section{"Aught unsavoury or unclean \\ Hath my insect never seen."}

Another ancient notion with regard to the bees, although more fragrant, was equally absurd-that the bees collect their young from the flowers and foliage of certain plants. The reed and the olive especially, had this virtue of generating infant bees attributed to them.

Aristotle and Pliny seem to have had quite upto-date ideas concerning the hive and its inmates, except in their designating the head of the hive to be a king instead of a queen.

Aristotle tells us that the kings generate both kings and workers, and the latter the drones.

It is right, he says, that the kings should remain inside the hive, unfettered by any employment, because they are made for the multiplication of the species. Aristotle also tells us that in his time 
some affirmed that the worker bees were the females and the drones the males: an opinion which he fights with a somewhat far-fetched analogy, that Nature would never give offensive armour to females!

Virgil describes the attachment of the bees to their sovereign with great truth and spirit in the following lines:

"Lydian nor Mede so much his king adores, Nor those on Nilus' or Hydaspes' shores; The state united stands while he remains;

But should he fall, what dire confusion reigns. Their waxen combs and honey, late their joy,

With grief and rage distracted, they destroy. He guards the works, with awe they him surround, And crowd about him with triumphant sound; Him frequent on their duteous shoulders bear, Bleed, fall, and die for him in glorious war."

To quote a later and more up-to-date authority on this subject, Réaumur, the great French scientist, says: "With regard to the ordinary attention and homage that they pay to their sovereign, the bees do more than respect their queen. They are constantly on the watch to make themselves useful to her, and to render her every kind office; they are for ever offering her honey; they lick her with their proboscis, and wherever she goes she has a court to attend upon her."

Then, again, think of the complicated mechanism of the hive, where all is done with exact and military precision, all the inmates doing their work quietly and silently, without any fuss or bother. To quote Maeterlinck's words:

"There are the nurses, who attend the nymphs 


\section{THE GLORY OF THE GARDEN}

and the larvæ; the ladies of honour who wait on the queen, and never allow her out of their sight; the house-bees who air, refresh, or heat the hive by fanning their wings, and hasten the evaporation of the honey that may be too highly charged with water; the architects, masons, and wax-workers who form the chain, and construct the combs; the foragers who sally forth to the flowers in search of the nectar that turns into honey, of the pollen that feeds the nymphs and larvæ, the propolis that welds and strengthens the buildings of the city, or the water and salt required by the youth of the nation.

"The orders have gone forth to the chemists, who ensure the preservation of the honey by letting a drop of formic acid fall in from the end of their sting; to the capsule-makers, who seal down the cells when the treasure is ripe; to the sweepers, who maintain public places and streets most irreproachably clean; to the bearers, whose duty it is to remove the corpses; and to the amazons of the guard, who keep watch on the threshold by day and by night, question comers and goers, recognise the novices who return from their very first flight, scare away vagabonds, marauders, and loiterers, expel all intruders, attack redoubtable foes in a body, and, if need be, barricade the entrance."

Such is the continual, daily work, methodical and organised, going on in each and every hive, and then human beings think that they are the only living creatures who know the meaning of work!

To quote once more from Bliss Carman in "A More Ancient Mariner," from whom came the verses at the beginning of this chapter: 


\section{SOME BEE LORE}

"He never could box the compass round;

He doesn't know port from starboard;

But he knows the gates of the sundown straits

Where the choicest goods are harboured.

"He never could see the Rule of Three,

But he knows a rule of thumb

Better than Euclid's, better than yours,

Or the teachers' yet to come.

"He drones along with his rough sea-song,

And the throat of a salty tar,

This devil-may-care, till he makes his lair,

By the light of a yellow star.

"He looks like a gentleman, lives like a lord, And works like a Trojan hero;

Then loafs all winter upon his hoard,

With the mercury at zero." 


\section{CHAPTER VII}

\section{SOME BIRD LORE}

"'The birds, who make sweet music for us all In our dark hours, as David did for Saul.

"Do you ne'er think what wondrous beings these?

Do you ne'er think who made them, and who taught The dialect they speak, where melodies

Alone are the interpreters of thought?

Whose household words are songs in many keys,

Sweeter than instrument of man e'er caught !

Whose habitations in the tree-tops even

Are half-way houses on the road to Heaven!"

LONGFELLOW: The Birds of Killingworth.

\section{Birds in the Garden.}

BIRDS are, speaking generally, absolutely essential in the garden, and they are far more friends than enemies of the gardener, if he would only realise this fact.

But because a blackbird or a thrush steals a few cherries or strawberries, a house-sparrow mischievously nips off a few crocus flowers in the spring, a chaffinch or greenfinch purloins a few seeds, or a bullfinch vigorously pulls off the buds of gooseberry or pear-forthwith, in the gardeners' estimation, all birds are enemies, and must be got rid of at once. All during the season of the "soft fruit" the patience of gardeners and owners of gardens certainly is apt to be somewhat tried by the birds, 
who will, especially during hot weather, make much havoc with the fruit.

And how many people look on this as otherwise than sheer theft? Yet there are two other points of view, and the first is, that very often thirst will drive the birds to the fruit, and if their needs were more thought of, and water supplied regularly in the garden, then the fruit crop might not suffer so badly.

Secondly, we should bear in mind that for services rendered the birds are surely entitled to a percentage of the fruit in each garden.

Joseph Addison writes on this subject: "There is another circumstance in which I am very particular, or, as my neighbours call me, very whimsical: as my garden invites into it all the birds of the country, by offering them the conveniency of springs and shades, solitude and shelter, I do not suffer anyone to destroy their nests in the spring, or drive them from their usual haunts in fruit time. I value my garden more for being full of blackbirds than cherries, and very frankly give them fruit for their songs. By this means, I have always the music of the season in its perfection, and am highly delighted to see the jay or the thrush hopping about my walks, and shooting before my eyes across the several little glades and alleys that I pass through."

The kind acts performed by many individual species of birds are manifold: for instance, in the case of blackbirds and thrushes, they are inveterate fruit-stealers, but at the same time their diet is very largely made up of slugs and snails in great quantities. The thrush especially, if left undis- 


\section{THE GLORY OF THE GARDEN}

turbed, will dispose of a large number of snails; he usually selects and keeps one flat stone on which to break the shell of the snail and get at the dainty morsel within. And one hears the steady crackcrack of the snail being beaten against the stone by the thrush's strong beak.

The chaffinch and the greenfinch feed on weeds and small caterpillars, being most active in tracking down the latter. Starlings feed on worms, leatherjackets, and practically any soil grubs. Robins and wrens are very fond of worms and small insects. The house-sparrow, our much-maligned friend, whom many people would like to exterminate altogether because (they say) he is so utterly useless, lives very largely on grubs and other insects. The seagull is very partial to leather-jackets and wireworms, whenever he can find any, and the magpie and the owl feed on mice, voles, and all surface caterpillars.

Surely if these birds render us such excellent service in attacking the chief pests that infest our crops we ought not to begrudge their levying a toll on a few fruits as a reward for their services.

Think of the dreary picture that Longfellow paints for us if we really did succeed in trapping and killing all the birds out of our gardens!

"Think of your woods and orchards without birds!

Of empty nests that cling to boughs and beams, As in an idiot's brain remembered words

Hang empty 'mid the cobwebs of his dreams! Will bleat of flocks or bellowing of herds

Make up for the lost music, when your teams Drag home the stingy harvest, and no more The feathered gleaners follow to your door ? 
"You call them thieves and pillagers; but know

They are the wingèd wardens of your farms, Who from the cornfields drive the insidious foe,

And from your harvests keep a hundred harms;

Even the blackest of them all, the crow,

Renders good service as your man-at-arms,

Crushing the beetle in his coat of mail, And crying havoc on the slug and snail."

One feels that one can endorse the terse, strong language of Dr. Abbott, the naturalist: "A creature that will destroy a song-bird's nest is a pest, and whether furred, feathered, four-legged, or a boy, ought to be exterminated."

It is undoubtedly a fact, and a sad one, that in America the bluebirds have had an extraordinarily hard time; they are among the most confiding and friendly of all the bird tribe, and yet they have been uncompromisingly sought and killed for their gay and beautiful plumage.

And it seems that the wee humming-birds, whose diminutive size should have secured them from harm, are seen oftener now on wearing apparel than on the flowers.

Whittier, one of the kindliest natured of men, was constrained to write on this subject:

"I could almost wish that the shooters of birds, the taxidermists who prepare them, and the fashionable wearers of their plumage, might share the penalty of the Ancient Mariner who shot the albatross."

Many students in ornithology are exceedingly wasteful of bird life, and the rarer becomes a species the less are the chances that any will escape. Every ambitious collector is anxious for a specimen; it 
matters not that the species has been often described, its structures and habits well known, the bird must pay with its life for the penalty of being rare.

Surely this is a burlesque on science, a travesty on the subject of natural history. But even this horrible wrong seems dwarfed when compared with the destruction of the birds for millinery and decorative purposes.

If the facts connected with this traffic could generally be made known, a thrill of indignation would take possession of every right-minded person, and the community, in wrath would demand that this outrage must cease; but, unfortunately, the killing is carried on surreptitiously, much of it in out-of-the-way places. In America, those who have investigated the subject know that thousands of men and boys all over the country, are regularly employed to kill and skin the native birds.

Attention need not be called to the individual uses of these decorations. They may be seen on the hats of rich and poor, old and young: a whole bird on one, a half-dozen wings on another; beaks and breasts on others; hateful emblems of thoughtless cruelty, most unbecoming to the women who wear them.

A few more years of such wanton warfare on the birds and it almost seems that men will walk the voiceless fields and woods where, instead of bright wings amid the green foliage and artistic structures filled with eggs and fluttering birds, only unsightly nests of crawling worms will dangle from leafless bush and tree.

In place of the gay carol of the bird voices, only 
the fretting hum of troublesome insects will worry the listening ear:

"What! would you rather see the incessant stir

Of insects in the windrows of the hay, And hear the locust and the grasshopper

Their melancholy hurdy-gurdies play?

Is this more pleasant to you than the whir

Of meadow-lark and her sweet roundelay,

Or twitter of little fieldfares, as you take

Your nooning in the shade of bush and brake?"

Emerson, speaking on this subject, says:

"We should go to the ornithologist with a new feeling, if he could teach us what the social birds say when they sit in the autumn council talking together in the trees. The want of sympathy makes his record a dull dictionary. His result is a dead bird. The bird is not in its ounces and inches, but in its relation to nature; and the skin or skeleton you show me is no more a heron than a heap of ashes or a bottle of gases into which his body has been reduced is Dante or Washington."

Amongst all the birds in this country, the robin and the wren have, perhaps, figured the most extensively in legend and plant lore-in fact, as the old ballad quaintly says:

"The Robin and the Wren

Are God Almighty's cock and hen."

They have both enjoyed an amount of protection almost amounting to superstition, though the wrens did suffer rather badly some few years ago from the attacks of schoolboys.

Noticing that the wrens usually kept to the shelter of the hedgerows and seldom ventured 
upon any lengthy flight, these boys, armed with sticks and stones, would beat on either side of the hedge until poor Jenny Wren was killed.

In the South of Ireland, a wren is carried about in great honour, to the accompaniment of the following verse:

"The Wren, the Wren, the King of all birds, Was caught St. Stephen's day in the furze; Although he's little, his family's great,

Then, pray, kind gen tlefolks, give him a treat."

Another old saying with regard to the wren runs thus: "It was decided in a parliament of the birds that the one who flew highest should be king. The wren hid itself on the eagle's back, and when the eagle had flown the highest, the wren fluttered a little higher still."

The robin seems through all the ages to have been regarded as a sacred bird, and in olden times was always associated with Christmas and Easter. $\mathrm{He}$ is the most trusting of all our garden birds, seeming to know no fear, and he delights in the companionship of all who work in gardens, following round with bright eyes, intently watchful on all worms, slugs, and other succulent morsels. The robin is, in fact, one of the most efficient members of the bird police force, who patrol our gardens and keep down insect thieves and criminals.

\section{The Legend of the Robin.}

Tradition tells us that he owes his ruddy breast to the fact that as Our Lord climbed upwards to Calvary bearing His cross and wearing the crown of thorns, a little bird with soft brown plumage 
was overwhelmed at the sight of the awful tragedy and fluttered round, trying its best to assist and cheer-striving with beak and claws to draw away the thorns running so deep into the holy brow, till in its efforts the robin's own soft breast was torn and bleeding, and Our Lord said to him: "Because you have tried to soothe My anguish, henceforth you shall bear the marks of My blood upon your breast, and for evermore you shall be loved and welcomed near the dwellings of men."

Another legend popularly believed of the robin in medirval times is that he often flies to Hades, bringing in his beak drops of water to assuage the thirst of the poor souls there, and in this act of charity his breast is scorched by the flames.

Whittier writes of this legend:

"He brings cool dew in his little bill,

And lets it fall on the souls of sin;

You can see the mark on his red breast still,

Of fires that scorch as he drops it in."

Another pretty belief about the robin tells us that he will cover up a dead body, as he is supposed to have done for the "Babes in the Wood."

"Covering with moss the dead's unclosèd eye,

The little redbreast teacheth charity."

St. Cuthbert and the Birds.

St. Cuthbert, in olden days, was one of the most famous and best-loved saints in all the North of England. He was a monk, who brought Christianity to the Farne Isles, dying in the year 687. The islands and the coast are famous as the haunt 


\section{THE GLORY OF THE GARDEN}

of thousands of wild birds, and St. Cuthbert, a man of gentle and humble spirit, found one of his chief joys in the companionship of the birds. Historians tell us that the seagulls would nestle in his bosom and feed from his hand, and he was especially fond of the eider ducks. $\mathrm{He}$ even gave up to his bird friends the scanty harvest of barley grown for his own use.

The Farne Isles are now kept as a sanctuary for wild birds, where they may not be molested, a memorial to St. Cuthbert that surely he must greatly appreciate!

"The lark upon his skyward way,

The robin on the hedgerow spray,

The bee within the wild thyme's bloom,

The owl amid the cypress gloom,

All sing in every varied tone

A Vesper to the Great Unknown."

Eliza Cook 


\section{CHAPTER VIII}

\section{SOME TREE LORE}

"If you could dance when Orpheus piped, Ye Oaks and Elms and Beeches, Try when a man of modern time Your courtesy beseeches.

'Twas but his fancy! Well, 'tis mine,

So do your best endeavour:

The facts of History pass away,

The thoughts may live for ever.

'They move, they start, they thrill, they dance,

They shake their boughs with pleasure, And flutter all their gay green leaves

Obedient to the measure.

They choose their partners: Oak and Beech

Pair off, a stately couple;

And Larch to Willow makes his bow,

Th' unbending to the supple."

Charles Mackay: The Dance of the Trees.

LEGEND tells us that in those far-away days of old, trees walked and talked as well as thought, and were much attracted by music. When Apollo and Orpheus played the harp, trees and cattle came together and crowded round them. Ovid writes: "There was a hill, and upon the hill, a most level space of a plain which the blades of grass made green; all shade was wanting in the spot. After the bard, sprung from the gods, had seated himself in this place, and touched the strings, a shade came over the spot. The tree of Chaonia was not absent, 


\section{THE GLORY OF THE GARDEN}

nor the groves of the Heliades, nor the mast tree with its lofty branches, nor the tender lime tree, nor yet the beech and the virgin laurel, and the brittle hazel, and the oak adapted for making spears, and the fir with knots, and the holm bending beneath its acorns, and the genial plane tree, and the parti-coloured maple, and the tine tree with its azure berries. You, too, the ivy tree with your creeping tendrils, and the elms clothed with vines; the ashes too, and the pitch trees, and the bending palms, the reward of the conquerors; the pine with its tufted foliage, and bristling at the top, pleasing to the mother of the gods.

"Such a grove of trees had the bard attracted round him, and he sat in the midst of an assembly of wild beasts, and a multitude of birds."

Amphion is one of the most famous of mythical musicians; he was given a lyre by Mercury, who taught him how to play upon it. It is said that when he played on his lyre stones moved of their own accord, and took their places in the wall with which he was fortifying the city.

" 'Tis said he had a tuneful tongue,

Such happy intonation,

Wherever he sat down and sung

He left a small plantation;

Wherever in a lonely grove

He set up his forlorn pipes,

The gouty oak began to move,

And flounder into hornpipes.

"The mountain stirred its bushy crown,

And as tradition teaches,

Young ashes pirouetted down,

Coquetting with young beeches; 


\section{SOME TREE LORE}

And briony vine and ivy wreath

Ran forward to his rhyming,

And from the valleys underneath

Came little copses climbing.

"The linden broke her ranks and rent

The woodbine wreaths that bind her,

And down the middle, buzz! she went

With all her bees behind her;

The poplars, in long order due,

With cypress promenaded,

The shock-head willows, two and two,

By rivers gallopaded.

"Came wet-shot alder from the wave,

Came yews, a dismal coterie;

Each plucked his one foot from the grave,

Poussetting with a sloe tree:

Old elms came breaking from the vine;

The vine streamed out to follow,

And, sweating rosin, plumped the pine

From many a cloudy hollow.

"And wasn't it a sight to see,

When, ere his song was ended,

Like some great landslip, tree by tree,

The countryside descended;

And shepherds, from the mountain-eaves

Looked down, half-pleased, half-frightened,

As dashed about the drunken leaves

The random sunshine lightened!"

Tennyson: Amphion.

In the olden days of myth and legend, it is recorded that people and nymphs were often transformed into trees, sometimes at their own request, but more often for offending the gods.

The Heliads, children of the sun, were changed to poplars, Altis to a pine, the mother of Adonis to a myrrh tree; an Apulian shepherd who mocked 


\section{8}

\section{THE GLORY OF THE GARDEN}

the nymphs was transformed to an olive tree, and his tears to bitter berries.

The fair virgin Daphne, at her own request, became a laurel, that she might escape from Apollo, who was in pursuit of her. Just as Apollo overtook her, a stiffness seized her limbs, and gradually she took on the appearance of a laurel tree. Apollo embraced the branches and lavished kisses on the wood. "Since thou canst not be my wife," said he, "thou shalt assuredly be my tree. I will wear thee for my crown. I will decorate thee with my harp and my quiver. When the Roman conquerors conduct the triumphal pomp to the Capitol, thou shalt be woven into wreaths for their brows. And, as eternal youth is mine, thou also shalt be always green, and thy leaf know no decay."

The beautiful Dryope was changed to a lotus tree for unwittingly plucking a blossom in which was enshrined the nymph Lotus.

A just doom met the two Eonian women, who, turning to flee, after murdering Orpheus, found their flight checked by the rapid lengthening of their toes. Soon their feet became rooted to the ground, their flesh turned to woody fibre, their hair and hands changed to leaves and branches, and a thick and rugged bark enclosed their shuddering forms.

The most interesting of these mythological metamorphoses is that related of Baucis and Philemon. Once on a time, Jupiter in human shape visited the land of Phrygia, and with him Mercury, without his wings.

They presented themselves as weary travellers at many a door, seeking rest and shelter, but found 
all closed, for it was late, and the inhospitable inhabitants would not disturb themselves.

At last a small thatched cottage received them, where Baucis, a pious old dame, and her husband Philemon had grown old together.

When the two guests crossed the threshold and bowed their heads to pass under the low door, the old man placed a seat, on which Baucis, bustling and attentive, spread a cloth, and begged them to sit down. Then she raked out the coals from the ashes, kindled a fire, and prepared some pot-herbs and bacon for them. A beechen bowl was filled with warm water that their guests might wash.

Meanwhile, the old woman set the table; one leg was shorter than the rest, but a piece of slate put under it restored the level. When it was steady, she rubbed the table down with sweet-smelling herbs, and then set thereon some of chaste Minerva's olives, some cornel berries preserved in vinegar, and added radishes and cheese, with eggs lightly cooked in the ashes. The meal was served in earthen dishes, with wooden cups, and some wine, not of the oldest, was added. Now while the repast proceeded, the old folks were astonished to see that the wine, as fast as it was poured out, renewed itself of its own accord. Struck with terror, Baucis and Philemon recognised their heavenly guests, and fell on their knees and implored forgiveness for their poor entertainment. But the gods made reply: "This inhospitable village shall pay the penalty of its impiety; you alone shall go free of chastisement. Quit your house and come with us to the top of yonder hill."

They hastened to obey, and saw the country 


\section{THE GLORY OF THE GARDEN}

behind them speedily sunk in a lake, and only their own small house left standing. Whilst they gazed in wonder this was changed. Columns took the place of the corner posts, the thatch grew yellow and appeared a gilded roof, and the floors became marble. Jupiter then spoke to the old couple, and said: "Tell us your wishes; what favours would you ask ?"

Philemon took counsel with Baucis for a moment, and then spoke: "We ask to be priests and guardians of this thy temple, and that one and the same hour may take us both from life."

Their prayer was granted. When they had attained a great age, as they stood one day before the temple, Baucis saw Philemon begin to put forth leaves, and Philemon saw Baucis changing in like manner. While they exchanged parting words, a leafy crown grew over their heads, Philemon changing to a grand and spreading oak, and Baucis into a tall and graceful lime.

According to many poets trees occupy an important place in the land of spirits.

When Dante and Virgil crossed the river Styx, they found tangled forests of brown foliage trees, each tree a living spirit, undergoing penance for sins committed against self, and although it was the lightest punishment in all these circles of misery, yet lamentations were issuing from them. Dante says: "We had put ourselves within a wood that was not marked with any path whatever, not green foliage, but of dusky colour; nor branches smooth, but gnarled and intermingled.

"Therefore the Master said: "If thou break off some little spray from any of these trees, the thought 
thou hast will wholly be made vain.' Then stretched I forth my hand a little further, and plucked a branchlet off a great thorn, and the trunks cried: 'Why dost thou mangle me? Why dost thou rend me? Hast thou no pity whatsoever? Men once we were, changed now to trees." "

But as they ascended up through Purgatorio to Paradiso, they found wondrous trees, some filled with fruit and bearing sweet incense.

Trees occupy a prominent place in the literature of all ages, and more especially in the myths handed down to us by Homer, Ovid, and Virgil.

The ancient Greeks and Romans believed that many trees held enshrined within their woody bark sylvan deities, whose lives were darkened when the trees were felled. These bright creatures inhabited every part of the tree, from the root to the smallest twig, giving them life and beauty, feeling and intelligence. It was they who shuddered and moaned in the storm, and shivered and grew pale at the approach of cold, and became glad again in the springtime, when their happy laughter rippled out in fluttering, joyous leaves and bright flowers.

The particular tribe of elves who inhabit woods and forests have always been known to the human race as the Sylvans, and in this family we find merry tribes of Dryads, Nymphs, Fauns, and Satyrs.

The Dryads were young and beautiful nymphs, who were always regarded as semi-goddesses, the name being derived from the Greek word, drus, meaning a tree.

The Hamadryads were of human shape from the 


\section{2. \\ THE GLORY OF THE GARDEN}

head to the waist, but their lower limbs were grown into the shape of trunks and roots of trees, and all their life and power ended when the tree was felled.

The class of woodland deities called by the Greeks Satyrs, and by the Romans Fauns, had the legs, feet, and ears of goats, and the rest of their body was human. They were said to preside over all vegetation, so they were treated with great respect by all the countryfolk, and duly propitiated with offerings of all the firstfruits of the earth.

"But let no impious axe profane the woods,

Or violate the sacred shades; the gods

Themselves inhabit there-some have beheld

Where drops of blood from wounded Oaks distilled;

Have seen the trembling boughs with horror shake;

So great a conscience did the ancients make

To cut down Oaks, that it was held a crime

In that obscure and superstitious time."

These woodland deities regarded with favour those who treated them kindly, but often meted out punishment to those who did them violence, as is recorded in the story of Rhecus and Erisichthon. The former, seeing an oak about to fall, propped it up, and stayed it in its place, and the grateful nymph who inhabited it rewarded the generous deed by fulfilling any request which Rhecus might like to make.

Erisichthon, on the other hand, was famous for "lifting up the axe against trees and despoiling forests"; he regarded neither the use nor the beauty of trees, and even felled the Dodonian oak that stood in the grove sacred to Ceres.

It was said of this famous tree that it towered above the other trees as loftily as the other trees 
towered above the grass, and that it was a wood in itself. When the Dryads remonstrated with Erisichthon, he boasted that he would fell the tree, even if it enshrined the goddess herself. When the grand old oak shuddered at the last stroke that was given it, a voice came from the trunk saying: "I, a nymph most pleasing to Ceres, am beneath this wood, and dying do rejoice at the punishment which will be meted out to thee."

The punishment which Ceres decreed for Erisichthon was that he should be tortured by famine, so dire and terrible that he was finally compelled to eat portions of his own body.

In most tree legends the oak is regarded as sacred, the reason probably being that the Druids offered sacrifices in oak groves, and consulted these trees in their worship. From this probably arises the generic name of the oak: Quercus, from quaro, to seek.

One of the famous oracles consulted by the priests was the Talking Oak of Dodona, and it possessed most miraculous powers. A staff cut from one of its branches always guided the traveller in paths of safety, and conducted him to the desired haven.

Mercury's wonderful cane must have come from this tree, and it is said that the vessel in which Jason went in search of the Golden Fleece, had her figurehead cut from a portion of one of its branches, and the success of the voyage was thereby assured.

Some of the groves were sacred to the celestial gods, and others to lesser deities. The forest of Mount Ida, the foster-home of Jupiter, was one 


\section{4

of these sacred groves. The trees here were proof against the elements, and vessels built from their timbers could withstand the winds and waves of the sea, and even the wrath of Neptune was unable to harm the mariners in these crafts. Virgil tells us that Æneas was allowed to build his ships from the pines of this forest, and that when the Latians attempted to burn them before Italy, Venus changed them to nymphs, and they sailed away into the air. At the marriage of Jupiter and Juno, the most noted gift to the bride was a tree from this grove, laden with golden fruit.

Since those days, through all the ages, this reverential and tender regard for trees has been implanted in the minds of all imaginative people, ancient and modern, sacred and profane, and the pure pleasure derived from their contemplation is peculiarly a part of the poet's dower.

The bards of Israel sing of the cedars of Lebanon, and use them as symbols of strength, beauty, grandeur, and grace. David was particularly fond of the cedar, and history relates that his dwelling was built entirely of this exquisite wood, a present from Hiram, King of Tyre.

Shakespeare's favourite tree seems to have been the pine, that towered above other trees as did his genius above that of other men; the wind playing through its needles was not to him, as to most people, a mournful melody, but an anthem of inspiration.

Coleridge is never tired of singing of the graceful birch, whom he names most fittingly the "Lady of the Woods."

Whittier and Longfellow are true to their own 
country, and their allegiance, even in their verses, does not waver from their own sugar maple.

Thoreau, the great French scientist, was a devoted student of the trees, and a worshipper at their shrines; he sympathised with their sylvan spirits, and communed with them. He looked upon the wanton destruction of a forest, or even a tree, as sacrilege, and "thanked God that these choppers were not able to cut down the clouds."

In speaking of the destruction of the pine forests, he says: "Strange that so few men ever come to the woods, to see how the tree lives and spires, lifting its evergreen arms to the sky to see its living success.

"Most men are content to see the broad boards and sticks of timber brought to market, deeming that the tree's success; but a dead pine cut down is no more a pine than a dead carcass is a man.

"It is not the lumberman who stands nearest the tree who understands it best and loves it most; it is not he who has bought the stumpage on which it stands, and who must cut into it to find if its heart be sound.

"All the trees shudder when that man steps on the forest floor. No, no; it is the poet who makes the truest use of the tree; he does not fondle it with an axe, nor tickle it with a saw, nor stroke it with a plane; he loves it as he does his living friends, and lets it stand. It is the living spirit of the tree with which I sympathise; it may be as immortal as I am, and perchance will go to as high a heaven, there to tower above me still."

In "The Charm of Gardens," Dion Clayton 


\section{THE GLORY OF THE GARDEN}

Calthrop writes: "So may trees be a solace in trouble, and secrets may be whispered to bushes of rosemary and lavender, who will yield their secret solace of peace, as the tree yields strength. All these things are written in a garden in coloured letters of gold, and green, and crimson, in blue and purple, orange and grey, and they are written for a purpose. And a man may seek diligently for the secret of this great book, and find nothing if he seek with his head alone. $\mathrm{He}$ will tell of the growth of trees, their years, their nature, their sickness.

"He will learn of the power of the sap which flows down from the tips of leaves to the great roots all snug in the soil; and he will learn of the veins in the leaves, and the properties of the gum of the bark, yet will he never learn that of which the tree speaks always, night and day-praising. The sky and the sea are blue, and they are things of mystery, deep and profound, and because of their depth and profundity they are blue. The grass and the trees, and the leaves of flowers are green. They are mysterious things, but they are nearer to man, and he has them to his hand to be near them, and get quick comfort of them.

"In this way can man regard the trees in his garden, and speak with them, loving them, and learning of them. And he may yet be an ordinary man, not poet or artist, but he must be mystic because he has the true sight. Many a man, stockbroker, clerk, painter, labourer, soldier, or whatever he seems to be, has his real being in these moments, and they are revealed through love or sorrow, but not by hard learning or text-books." 


\section{SOME TREE LORE}

"If thou art worn and hard beset

With sorrows, that thou wouldst forget,

If thou wouldst read a lesson, that will keep

Thy heart from fainting and thy soul from sleep,

Go to the woods and hills!-No tears

Dim the sweet look that Nature wears."

LONGFELLOW. 


\section{CHAPTER IX}

SOME WEATHER LORE

"Weather-wise, foolish otherwise."

WhAT gave rise to this curious old couplet, and is there any truth in it? If so, it is rather unfortunate for the gardener, for no man is asked for an opinion on the weather quite so much. Indeed, it would seem almost as though the public had given him a certain professorship in the matter, and his statement on the subject, when once pronounced, is taken to be as unalterable as the laws of the Medes and Persians. And certainly close contact with Nature in the outdoor conditions of everyday life, should develop the faculties of observation for signs of " rain" and "fair." Doubtless in many cases it is these men of the soil who have given rise to, and even invented, the rhymes and superstitions in connection with weather portents.

For instance, signs of bad weather to come: That the pimpernel closes her eye; that the down will fly off the dandelion, though there be no wind; heliotrope and marigold flowers close their petals. That, so they say, the cat will sit by the fire and clean her whiskers.

"Evening red and morning grey,

Send the traveller on his way,

But evening grey and morning red,

Send the traveller wet to bed." 
This is a verse full of ripe experience, and one of the old-fashioned maxims in which we can have the fullest confidence, finding that practically there is always truth in the old adage:

"A rainbow in the morning

Is the shepherd's warning,

But a rainbow at night

Is the shepherd's delight."

This weather portent is, perhaps, more a sign for shepherds and travellers, than for gardeners and other ordinary folk who work by day, and can hardly be expected to watch for rainbows by night, to the detriment of their night's rest, and likewise their morning temper.

When the "distant hills look near" it is an infallible sign of rain, and many times one hears the saying in the country, "Such a place is too clear to-day," or, "One can see such a land much too well," and this means near rain. Just before rain it can often be observed that toads will walk out across the road, and frogs will change colour before a storm, losing their bright green or yellow, and turning to a dull and dirty brown.

There is a saying that "the new moon with the old moon in her lap comes before rain." And of the bur or halo to be seen at times round the moon: "Near bur, far rain."

A rather curious countryside superstition is heard sometimes concerning the weather on February 2.

"On Candlemas Day if the sun shines clear,

The Shepherd had rather see his wife on the bier."

"March dry, good rye,

April wet, good wheat." 
"The grass that grows in Janiveer

Grows no more all the year."

There is a "weather lore" rhyme about the gardener's pert friend, the robin, which runs thus:

"If the robin sings in the bush, Then the weather will be coarse;

But if the robin sings in the barn,

Then the weather will be warm."

Of the pigeon, with his sentimental voice, another rhyme says:

"If the pigeons go a-benting,

Then the farmers lie lamenting."

There are some very homely weather signs known to all children which often come very true, as for instance:

"When it rains before seven,

It will be fine before eleven."

"Between twelve and two

You'll see what the day will do."

"If the ash is out before the oak

We shall surely get a soak,

But if the oak before the ash

We shall but get a splash."

And how eagerly children go about the countryside searching for the "oak before the ash," and also how those two trees seem to know what is expected of them, and to prophesy accordingly as they have been ordered by Dame Nature!

But it is really to the wind that the gardener looks most, and if he is so fortunate as to have a weathercock in his garden he will note each turn of the wind. If he has no weathercock then he 
will read the wind by the smoke of chimneys or the turn of the leaves of trees.

A very cryptic saying concerning a windy sky enlightens us thus far:

\section{"A mackerel sky}

Is very wet or very dry." that:

Another wind prophecy, nearly always true, is "When it rains with the wind in the east, It rains for twenty-four hours at least."

Another rhyme concerning the wind's action on the weather runs thus:

"When the wind is in the south,

'Tis in the rain's mouth;

When the wind is in the east,

'Tis neither good for man or beast."

A West Country saying is that: "As hedgehogs do foresee evening storms, so wise men are for fortune still prepared." This they say because the story runs that a hedgehog builds his nest with the opening made to face the mildest quarter thereabout and the back to the most prevalent wind.

\section{St. Martin's Summer.}

St. Martin, like St. Luke, has his "Little Summer" beginning on his day, November II, It is referred to by Shakespeare, in "Henry VI.," Part I., Act"I., where Joan of Arc says:

"This night the siege assuredly I'll raise:

Expect St. Martin's summer, halcyon days." 


\title{
82 THE GLORY OF THE GARDEN
}

There are many old rhymes and proverbs associated with Martinmas:

\author{
"On St. Martin's Day \\ Your fires lay."
}

"Young and old must go clad at Martinmas."

"If there is ice that will bear a duck before Martinmas there will be none that will bear a goose all the winter."

"If the wind is in the south-west at Martinmas, It keeps there till after Candlemas" (February 2).

This weather lore is naturally gleaned out of many years, some of the sayings being of real antiquity, others perhaps of more recent invention.

In spite of them all, you will find that many people have a different method of reading the sky, some, for instance, contending that mares'-tails in the sky come after great storms, while others tell you that they are the portent of a gale.

ST. MARTIN'S SUMMER

"Though flowers have perished at the touch

Of frost, the early comer

I hail, the season loved so much,

The good St. Martin's Summer.

"The Summer and the Winter here,

Midway a truce are holding;

A soft consenting atmosphere,

Their tents of peace enfolding.

"Less drear the winter night shall be,

If memory cheer and hearten

Its heavy hours with thoughts of thee,

Sweet summer of St. Martin."

WhITTIER 


\section{CHAPTER X}

\section{THE MOON AND PLANT GROWTH}

"Sow peason and beanes in the wane of the moone,

Who soweth them sooner, he soweth too soone, That they with the planet may rest and arise,

And flourish with bearing most plentiful wise."

Thomas Tusser: Five Hundred Points of Good Husbandrie (1562).

During the Middle Ages, and even up till about two centuries ago, there was a very widespread belief that every plant was under the direct influence of some particular planet, and in the writings of some of the old herbalists we find much interesting information on this subject. Aubrey says that "if a plant be not gathered according to the rules of astrology, it hath little or no virtue in it."

Nicholas Culpepper set up in Spitalfields, about the year I640, as an astrologer and physician.

He was highly unpopular with the medical profession, which is hardly surprising, when we consider the way in which he speaks of them in his book as, "a company of proud, insulting, domineering doctors, whose wits were born about 500 years before themselves." In "The British Herbal and Family Physician" he gives a list of some 500 plants, and the names of the planets which govern them: "Such as are astrologers (and indeed none else are fit to make physicians), such I advise: let the planet that governs the Herb be angular, and the 
stronger the better; if they can, in Herbs of Saturn, let Saturn be in the ascendant; in the Herbs of Mars, let Mars be in the mid-heaven, for in those houses they delight; let the Moon apply to them by good aspect, and let her not be in the houses of her enemies; if you cannot well stay till she apply to them, let her apply to a Planet of the same triplicity; if you cannot meet that time neither, let her be with a fixed star of their Nature."

In Deuteronomy (xxxiii. I4) we read that precious things are put forth by the moon, but precious fruits by the sun; and it certainly does seem remarkable, that though in all ages, the sun has been worshipped, as being the supreme and ruling luminary, from whose life-giving rays all vegetation drew its existence, at the same time, there should have been a firm belief, that the growth and decay of plants were associated most intimately with the waxing and waning of the moon.

Through all the ages the sun and the moon have ranked high among the Nature gods, and even to this day they have obeisance done to them among some of the heathen tribes.

Survivals of the ancient rite of sun-worship may be traced in the custom of turning to the east, as well as in the bonfires set ablaze on the hills on Easter morning, which custom is still observed in the Greek Church.

There is a curious old Nature myth which runs thus:

"The Moon is a woman, and the Sun also; the Stars are the Moon's children, and the Sun had in old days as many. Fearing, however, that mankind could not bear so much brightness and heat, 
THE MOON AND PLANT GROWTH 85

they agreed each to devour her children; but the Moon, instead of eating up her Stars, hid them from the Sun's sight, who, believing them all devoured, ate up her own; no sooner had she done this than the Moon brought forth her family out of their hiding-place. When the Sun saw them, filled with rage, she chased the Moon to kill her; the chase has lasted ever since, and sometimes the Sun even comes near enough to bite the Moon, and that is an eclipse; the Sun, as men may see, devours her Stars at dawn, and the Moon hides hers all day while the Sun is near, and only brings them out at night when her pursuer is far away."

In old almanacs we find the supremacy of the moon over plant growth fully admitted, although the reasoning is sometimes rather abstruse and difficult to our modern intelligence.

In Wing's Almanac for I66I we read: "It is a common, observation in astrology, and confirmed by experience, that what corn or tree soever are set or sown when the sun or moon is eclipsed, and the unfortunate planets predominate, seldom or never come to good."

Devonshire farmers have, from time immemorial, made it a rule to gather their apples for storing at the wane of the moon; the reason being that during the moon's increase it is said that the apples are full, and therefore will not keep. Bacon seems to have considered that even the "braine of man waxeth moister and fuller upon the Full of the Moon." And as we study all these old writings, we come to realise that the moon was held to have a very special and predominant influence over vegetation, and it was said that there existed a 
sympathy between growing and declining nature and the moon's wax and wane.

It is said that if timber is felled when the moon is on the increase it will decay; and that it should always be cut when the moon is on the wane.

There seems to be no practical reason for this, yet it is a belief which is common in many countries; and professional woodcutters, whose occupation it is to fell timber, state, as the actual result of their own observations, that the belief is well founded.

The theory given to account for this is that as the moon grows the sap rises, and the wood is, therefore, less dense than when the moon is waning, because at that time the sap declines.

The belief in the moon's influence as regards timber extends also to vegetables, and was universally practised in England in former times, although one hears less about it now. Just occasionally one meets with an old-fashioned gardener who must sow or plant according to the moon.

They act upon the maxim that root crops should be sown when the moon is decreasing, and plants such as peas and beans, which bear their crops on the branches, between the new and the full moon.

Tusser writes, with regard to grafting:

"In March is good graffing, the skilful do know, So long as the wind in the East do not blow, From Moone being changed, till past be the prime,

For graffing and cropping is very good time."

In "The Garden of Eden," an old gardening book compiled by Sir Hugh Plat in the year I600, constant allusions are made to the necessity of studying the moon's phases in gardening and 
grafting operations. The writer even considered that the moon would exercise her powers in making single flowers double, if only she were respectfully courted. For instance: "Remove a plant of stock Gilliflowers when it is a little wooded, and not too green, and water it presently. Doe this three days after the full, and remove it twice more before the change. Doe this in barren ground; and likewise, three days after the next full Moone remove again; and then remove once more before the change. Then at the third full Moone, viz: eight days after, remove again, and set it in very rich ground, and this will make it to bring forth a double flower; but if your stock Gilliflowers once spindle, then you may not remove them. Also, you must make Tulippes double in this manner. Some think by cutting them at every full Moone before they beare to make them at length to beare double."

In "The Countryman's Recreation," published in 1640 , the following advice is given:

"From the Ist day of the New Moon unto the I 3 th day thereof is good for to plant, or graffe, or sow, and for great need some doe take unto the I7th or I8th day thereof, and not after, neither grafte nor sow, but as is afore-mentioned, a day or two afore the change, the best signes are Taurus, Virgo, or Capricorne." With regard to the treatment of fruit trees, the author goes on to tell us: "That trees which come of nuttes should be set in the autumn in the change or increase of the Moone, fruit, desired of good colour, and untouched by froste, should be gathered, when the time is faire and dry, and the Moone in her decreasing."

In "The Expert Gardener," published in I640, 
a work stated to be "faithfully collected out of sundry Dutch and French authors," a chapter is devoted entirely to the times and seasons which should be selected "to sow and replant all manner of seeds," with special reference to the phases of the moon.

John Evelyn, in his "Sylva, or a Discourse on Forest Trees," first published in 1662 , remarks on the attention paid by woodmen to the moon's influence on trees. He writes: "Then for the age of the Moon, it has religiously been observed; and that Diana's presidency 'in sylvis' was not so much celebrated to credit the fictions of the poets, as for the dominion of that moist planet and her influence over timber."

\section{The Man in the Moon.}

There are, as may well be imagined, several curious legends to account for the Man in the Moon. One version says that on a Christmas Eve a peasant felt a great desire to eat a cabbage; and having none himself, he crept stealthily into his neighbour's garden to cut some. Just as he had filled his basket, the Christ-Child rode past on a white horse, and said: "Because thou hast stolen in this holy night, thou shalt immediately sit in the Moon with thy basket of cabbage."

Another version has it that a man stole some vine shoots from a neighbour's garden on a Sunday, and when taxed with the theft the culprit loudly proclaimed his innocence, exclaiming: "If I have committed this crime, may I be sent to the Moon." There he was sent at once, and there he remains to this day. 


\section{THE MOON AND PLANT GROWTH 89}

Yet another version relates that a man stole a bundle of wood on a Sunday, because he thought he would have the forest quietly to himself on that day. However, as he left the forest he met a stranger, who turned out to be none other than God Himself. After duly reproving the thief, the Almighty gave him the choice as to whether he would be banished to the sun or the moon.

The man chose the latter, declaring he would rather freeze in the moon than burn in the sun; and so the Broom-man came into the moon, with his faggot on his back.

Rapin, in his poem on "Gardens," has the following lines bearing on the moon:

"If you with flowers would stock the pregnant earth,

Mark well the Moon propitious to their birth:

For Earth the silent midnight queen obeys,

And waits her course, who, clad in silver rays, Th' Eternal round of times and seasons guides,

Controls the air, and o'er the wind presides.

Four days expired you have your time to sow,

Till to the full th' increasing Moon shall grow;

This past, your labour you in vain bestow:

Nor let the gardener dare to plant a flower

While on his work the heavens ill-boding lower;

When Moons forbid, forbidding Moons obey, And hasten when the Stars inviting beams display." 


\section{CHAPTER XI}

MAGICAL PLANTS

" I'll seek a four-leaved Clover,

In all the Fairy dells,

And if I find the charmed leaf,

Oh ! how I'll weave my spells."

S. Lover.

Plants used for Charms and Spells.

IN the olden days, the sick and poor were accustomed to seek and find the relief and cure of their various ailments at the hands of the monks and nuns, but after the Reformation it seems that this healing art was gradually relegated to the wise woman of the village, who was, more often than not, a witch. One of the most curious and remarkable of these many old superstitions was the belief that diseases could be transferred from human beings to trees. Children were passed through cleft trees to cast out all witchcraft, and to protect them from the influence of witches; and sometimes they were passed through the branches of a maple, in order that they might be long-lived.

Patients with the ague were directed to proceed, without speaking or crossing water, to a large and lofty willow, to make a gash in it, breathe three times into the crevice, close it quickly, hasten away without looking back, and if they did this correctly, the ague was warranted to leave them. 
The origin of this superstition is said to lie in the fact that the country people, much struck with the affinity that exists between the animal and the vegetable world, came in course of time to think that the same demon caused the diseases of plants as of man. Therefore, in order to safeguard mankind, it was necessary to confine the demon in the plant.

A very old belief existed that diseases could be got rid of by burying them; and even in the tenth century there is a case of epilepsy cured by means of a buried peach-blossom, so Ratherius relates.

The Druids, besides being priests, prophets, and legislators, were also physicians, and they were well acquainted with the means of producing trances and ecstasies; and as one of their chief medical appliances they made use of the mistletoe, which they gathered at appointed times, with very solemn ceremonies, and considered it as a special gift from heaven. This plant grew on the oak, the sacred tree of the Celts and Druids; it was held in the highest reverence, and both priests and people regarded it as divine.

"The mystic Mistletoe,

Which has not root, and cannot grow,

Or prosper but by that same tree

It clings to."

The sacred oak itself was thought to possess certain magical properties in calling forth the spirit of prophecy, and so we find the altars of the Druids were often erected beneath some venerated oak tree in the secluded recesses of the sacred grove. The Greeks had their prophetic oaks that 
delivered the oracles of Jupiter in the sacred grove of Dodona.

"Such honours famed Dodona's grove acquired As justly due to trees by heaven inspired;

When once her Oaks did fate's decrees reveal, And taught wise men truths future to foretell."

The Onion, if suspended in a room, possesses the magical powers of attracting and absorbing maladies that would otherwise attack the inmates. They are also said to keep away witches and evil spirits. It was probably a form of ascetic self-denial which caused the Egyptian priests to abstain from the use of onions as food, and this led to the superstitious reverence with which onions were regarded by the bulk of the people.

Lucian, when giving an account of the different deities worshipped in Egypt, states that the "inhabitants of Pelusium adore the onion."

The Egyptians were often reproached for swearing by the leeks, garlic, and onions in their gardens; and Pliny says: "The onion and garlic are among the gods of Egypt, and by these they make their oaths," an absurdity which did not escape the scourge of Juvenal, whose nation, however, was not any the less absurdly superstitious than that against which his satire was directed.

But whilst some of the people did not dare to eat leeks, garlic, or onions, for fear of injuring their gods, others fed on them with enthusiasm, " excited by the zest of appetite, even if not of religious fervour."

"Such savoury deities must sure be good,

Which serve at once for worship and for food." 
But on the other hand:

" How Egypt, mad with superstition grown,

Makes gods of monsters, but too well is known;

'Tis mortal sin an Onion to devour;

Each clove of Garlic has a sacred power.

Religious nation, sure and blessed abodes,

Where every garden is o'errun with gods."

The St. Fobn's Wort (called of old Fuga damonum) is a preservative against tempests, thunder, and evil spirits, and possesses many magical properties.

The Peony drives away tempests and dispels enchantments.

The Four-leaved Clover is a thoroughly magical plant, and he who carries it on his person will be successful in any undertaking, and will have the power of detecting the presence, or even the approach, of evil spirits.

In mediæval days, when sorcery flourished, it was thought that fern-seed imparted to its owner the power of resisting magical spells and incantations.

The ancients believed that the fern had no seeds, but our ancestors thought it had seed which was invisible. So, working on the fantastic doctrine of signatures, they concluded that those who possessed the secret of wearing this seed about them would therefore become invisible. Thus in "Henry IV." Gadshill says: "We have the receipt of fern-seed, we walk invisible."

The old English tradition is that the fern flowers and seeds only at I 2 o'clock on Midsummer night (St. John's Eve), just at the precise moment at which the saint was born; so at that time it must 


\section{THE GLORY OF THE GARDEN}

be searched for and gathered, and will then display its magic powers.

"But on St. John's mysterious night,

Sacred to many a wizard spell,

The hour when first to human sight

Confest, the mystic Fern-seed fell."

An old writer on this subject says: "The fern flowers on Midsummer night at I2 o'clock and drives away all unclean spirits. First of all, it puts forth buds, which afterwards expand, and then open, and finally change into flowers of a dark red hue. At midnight the flower opens to its fullest extent, and illuminates everything around. But at that precise moment a demon plucks it from its stalk. Whoever wishes to procure this flower must be in the forest before midnight, locate himself near the fern, and trace a circle around it. When the devil approaches and calls, feigning the voice of a parent or sweetheart, no attention must be paid, nor must the head be turned, for if it is, it will remain so.

"Whoever becomes the happy possessor of the flower has nothing to fear: by its means, he can recover lost treasure, become invisible, rule on earth, and under water, and defy the devil."

The fairies, commanded by their queen, and the demons, commanded by Satan, engage in fierce combats at this mysterious time for the possession of the invisible seed.

In many countries, before the break of day on St. John's morning, the dew which has fallen on vegetation is gathered with great care. This dew is greatly renowned, for it purifies all the noxious 
plants, and imparts to certain others a fabulous power.

By some it is treasured because it is believed to preserve the eyes from all harm during the succeeding year, and others say that the dew is reputed to renew the roots of the hair on the baldest of heads!

There seems to be more plant magic woven round Midsummer Day than is connected with any other one particular date. Take, for instance, the fern seed, and then the St. John's Wort. Legend tells us that if after sunset on St. John's Eve (June 23) you should happen to step on this plant, a fairy horse will arise out of the ground, who will carry you gloriously all through the night, to leave you, wherever you might happen to be, when the first ray of the rising sun strikes the world. It might be rather awkward if your fairy steed should see fit to deposit you several miles from your work.

In days of old it was the custom of timorous folk to gather pieces of St. John's Wort at midnight on St. John's Eve, as it was said that this plant, hung over the doorway of dwelling-places, would effectually exclude all fairy and elfin visitors.

The St. John's Wort is said to be a plant thoroughly detested by witches, who are heartily scared when in its neighbourhood:

"St. John's Wort, scaring from the midnight heath

The witch and goblin, with its spicy breath."

In former times this plant was also known as Sol terrestris, the terrestrial sun, because it was believed that all the spirits of darkness vanish at the approach of the sun; and also St. John's Day 
96 THE GLORY OF THE GARDEN

falls on the summer solstice, June 24, the last of the three days which mark the culminating point of the solar ascension; the day when in some latitudes the sun never sets, and the heavens are illuminated and radiant with its glory all through the night.

Some few plants, like the well-known sesame of the "Arabian Nights," are credited with the power of opening doors and obtaining an entry into subterranean caverns and mountain-sides.

The mistletoe, in addition to its miraculous medicinal virtues, possesses the power of opening all locks, as have also the artemisia, the vervain, and the mandrake.

\section{The Magic Wand and Divining Rod.}

The employment of magic wands and staffs was in vogue among the ancient Egyptians and Chaldeans, who imparted the knowledge of this system of divination to the Hebrews dwelling among them.

Thus we find the prophet Hosea says: "My people ask counsel at their stocks, and their staff declareth unto them." Rhabdomancy, or divination by means of a rod, was practised by the ancient Greeks and Romans, and the art was known in England, though now it is almost forgotten. In China and Eastern lands the art still flourishes, and various kinds of plants and trees are employed, the principal being the hazel, osier, and blackthorn.

The Druids used to cut their divining 'rods from the apple tree. In competent hands, the golden rod is said to point to hidden springs of water, as well as to hidden treasures of gold and silver. 
"Some sorcerers do boast they have a rod,

Gathered with vows and sacrifice,

That, borne aloft, will strangely nod

To hidden treasure where it lies."

Hazel has always been the favourite tree amongst us to be employed for the divining rod, though peach, osier, and blackthorn have also been used for this purpose. Elder must never be employed under any circumstances.

The Chinese still abide by the venerable instructions that the operation must be performed so that the eastern and western sun shone through the fork of the rod; and their magic wands are cut usually from the peach, on the night preceding the new year, which always commences with the first moon after the winter solstice.

The following directions are culled from an old book of magic: "The rod must be cut at Midsummer night, or when the stars are in a particularly favourable condition, and in cutting it one must face the east, so that the rod shall be one which catches the first rays of the morning sun, or, as some say, the eastern and western sun must shine through the fork of the rod, otherwise it will prove of no avail. The shape of the rod is similar to the letter $Y$, and when in operation the hands usually grasp each side of the diverging arms, and allow the unforked part to point outwards.

"The seventh son of a seventh son is the most successful person to use the rod."

"Mysterious plant! whose golden tresses wave With a sad beauty in the dying year, Blooming amid November's frost severe, Like the pale corpse-light o'er the recent grave! 


\section{THE GLORY OF THE GARDEN}

If shepherds tell us true, thy wood has power, With gracious influence, to avert the harm Of ominous planets, and the fatal charm Of spirits wandering at the midnight hour; And thou canst point where buried treasures lie." Anon.: To the Witch Hazel. 


\section{CHAPTER XII}

WITCHES AND THEIR FLOWER LORE

"From the deep mine rush wildly out

The troop of Gnomes in hellish rout;

Forth to the Witches' club they fly;

The Griffins watch as they go by.

The horn of Satan grimly sounds;

On Blocksberg's flanks strange din resounds, And Spectres crowd its summits high."

Hecate, the Grecian goddess of the infernal regions, presided over magic and enchantment, and may well be styled the goddess, queen, and patroness of all witches and sorcerers. She was acquainted with the properties of every herb, and imparted this knowledge to her daughters, Medea and Circe.

The following is an old derivation of the word "witch": "A witch is a wise woman, one who can see spirits, and in virtue of her supernatural gaze can enchant or bewitch or fascinate those on whom she may fix her eye."

Mr. Conway, in his treatise on "Mystic Trees and Flowers," says: "The common name of the witch, hag, is the same as haw, the hawthorn being the hedgethorn. This coincidence may not, however, be due to the magical craft of the witch, but only to the habit of those, presumed to be such, of sitting under the hedges."

Witches have been divided into three kinds: black, white, and grey. The black, or bad, witch 


\section{THE GLORY OF THE GARDEN}

is always mischievous; but the white witches are kindly disposed, and can tell who it is that has bewitched cattle or render assistance to people who have been subject to the power of witchcraft. The grey witch is a mixture of the white and the black, and can help or hurt, as her mood dictates.

Witches are fond of riding about through the air in the dead of night, and perform long journeys to attend their meetings. Their favourite steeds for these excursions are besoms, which are generally to be found fairly near at hand; bulrushes are also used for locomotive purposes, as well as the broom and the thorn.

William of Auvergne, who wrote in the thirteenth century, says that when the witches of his time wished to go to the place of rendezvous, they took a reed or cane, and on making some magical signs and uttering certain barbarous words it became transformed into a horse, which carried them to their destination most extraordinarily quickly.

In nearly every case it will be found that the plants and flowers beloved of witches are also spoken of as "holding witches of their will"; but this need cause us little surprise, for the people of Eastern countries, firmly believe that the plants and materials employed by magicians, sorcerers, and other dealers in black magic, are equally efficacious if employed against their charms and spells.

It is recorded that, during the time of the witch persecutions, whoever found himself unexpectedly under an elder tree, was involuntarily seized with such horror, that in all probability he fell into an hysterical state. Although not one of the trees 
dedicated to Hecate and her witch progeny, the elder seems to have always possessed a weird attraction for mischievous elves and witches, who are fond of seeking the shelter of its branches, and also bury their satanic offspring beneath its roots.

The ill-famed Cercis siliquastrum, or judas tree, is reputed to be specially haunted by witches, who experience a grim pleasure in assembling round the tree on which the traitor Judas hanged himself. Perhaps it is they who have spread the tradition that death overtakes anyone who is so unfortunate as to fall into one of these trees.

One of the greatest arts in the knowledge of witches was the concoction of noxious or deadly potions, from various herbs with which they were enabled to work their spells.

The Vervain, or Verbena, was a sacred plant among the Greeks, and was regarded by the Druids with great reverence. It was never gathered without religious ceremonies, almost or quite equal in solemnity to those performed at the cutting of the mistletoe. It was much esteemed as a most powerful ingredient in love potions and other magic preparations, and could be used freely either by or against witches.

Rue was another magic plant, and was said to have a wonderful effect on the eyes, bestowing second sight. Milton represents St. Michael as purging Adam's eyes with it:

"To nobler sights

Michael from Adam's eyes the film removed Which that false fruit which promised clearer sight Had bred; then purged with Euphrasie and Rue The visual nerve, for he had much to see." 


\section{IO2 THE GLORY OF THE GARDEN}

In reading accounts of the witch times, one notices very forcibly that the plants employed by the witches are nearly always vervain and rue.

The Foxglove was in high repute among witches at one time, and it was said that they liked to decorate their fingers with its flowers, on which account they were known as "Witches' Thimbles." The Irish represent the Shelfo, one of their numerous species of sprites, as wearing the corolla of the foxglove on its head. Other plants beloved of witches are the hemlock, St. John's wort, and deadly nightshade, whose juices are infused into the baleful draughts prepared for their enemies.

The Deadly Nigbtshade, whose correct name is Atropa belladonna, is extremely poisonous, and a plant of ill omen; Gerarde, the old herbalist, says of it: "If you will follow my counsel, deale not with the same in any case, and banish it from your gardens, and the use of it also, being a plant so furious and deadly, for it bringeth such as have eaten thereof into a dead sleepe, wherein many have died." There is an ancient belief that the deadly nightshade is the form of a fatal enchantress or witch, called Atropa.

Every part of the plant is most virulently poisonous, root, stem, leaves, and the little black berries, of which William Wetmore Story in the "Passing of Summer" writes:

"While the Belladonna, so wickedly fair,

Shorn of the purple flowers that crowned her, Is telling her Borgian beads in despair."

The Sabbath of Witches is a meeting to which the sisterhood, after having been anointed with 
WITCHES AND THEIR FLOWER LORE IO3

certain magical ointments, provided by their infernal leader, are supposed to be carried through the air on broomsticks. Butler, in his "Hudibras," says of this:

" Or trip it o'er the water quicker

Than witches when their staves they liquor, As some report."

There seems to have been much controversy about the popular idea of witches flying, and many of the old writers think this is only an illusion, part of the enactment of a dream. This idea is expressed by Oldham, when he writes:

"As men in sleep, though motionless they lie, Fledged by a dream, believe they mount and fly, So Witches some enchanted wand bestride, And think they through the airy regions ride."

Some plants confer on the people who employ them the power of detecting witches, or even of seeing them. Some say that the green juice of the inner bark of the elder is used for anointing the eyes. Any baptised person, whose eyes are touched with it, can see what the witches are doing in any part of the world.

In Denmark, there is a superstition that if anyone will take his stand under an elder tree at I2 o'clock on Midsummer Eve, he will be able to see the king of the elves go by, attended by his train.

The Snapdragon was said to have a supernatural influence and to possess the power of destroying charms.

There used to be a very widespread belief in the 


\section{I04 THE GLORY OF THE GARDEN}

efficacy of rosemary as a counter-charm against witchcraft; probably this was the reason for its use at weddings and funerals, and for its presence in the dock of the accused in courts of justice.

Aconite is a plant with a bad name, its Indian name of "Ativisha" meaning supreme poison; it has always ranked very high amongst the herbs used by witches.

The aconite was held sacred to Hecate, in whose garden it grew, and whence, according to Ovid, it was first sown by Cerberus, that many-headed monster dog, keeper of the entrance to Hades. Hercules undertook to bring this great brute to earth, and this was his twelfth labour, for he was to use no arms or spells, only physical force. And from the foam that sprang from the dog's mouth arose the aconite, plant of ill omen.

The ancients used aconite to poison their arrow-heads, and in Norse mythology the hood of the aconite represents the cap of darkness, which enabled those who carried it to become invisible, and formed part of Odin's attire-Odin's helm, more generally called Thor's hat and Tyr's helm.

When the Benedictines invaded the realm of Thor it became " monk's hood," the cowl of the holy monks replacing the helm of 'Tyr.

Aconitum is amongst the most malignant poisons, and was employed by Medea in her cauldron of magic herbs, and it was with this that she tried to kill Theseus when he returned to King Æggeus, his father. But he suspected her evil designs, and insisted that she must first taste of the cup which she had handed to him, whereupon she dropped the cup and fled precipitately. And when the wine 
WITCHES AND THEIR FLOWER LORE IO5

bubbled over the pavement, the stones crumbled and hissed under the venom of the poison.

Hemlock is one of the most poisonous of a suspicious family: "The great hemlock doubtless is not possessed of any one good faculty, as appeareth by his loathsome smell, and other apparent signs"; and with this evil character the hemlock was considered a fitting ingredient of witches' broth. As a poison it has an evil notoriety, as being the poison by means of which Socrates was put to death.

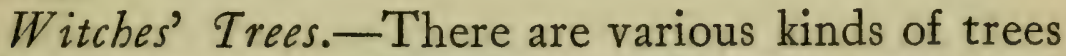
whose names are, directly or indirectly, associated with witches, such as the witch-elm and the witchhazel. We are told that "witch" is a mistaken spelling for "wych," yet it seems from the fact that the hazel was employed for making divining rods that the trees must have been connected in some way with magic.

The hawthorn used to be hung up at the entrance of houses in May to guard the dwelling from witches. Witches detest yew trees, and it is probably for this reason that yews have been planted so universally in churchyards from the earliest times, so that the witches may be unable to gain access, and disturb the calm of these holy places.

The burning of juniper wood was said to expel evil spirits, and the old herbalists recommend juniper berries for use as counter-poisons; and water in which these berries had been steeped, was said to be most healthful and useful against poisons, and all forms of plague or pestilence.

In Italy, boughs of juniper are hung over the doorway, as there is a belief that any witches who 


\section{I06 THE GLORY OF THE GARDEN}

are about, will be seized with an irresistible desire to count the leaves, and these being so very numerous they are sure to become impatient, and take themselves off in high dudgeon, without entering the house.

The Rowan, or Mountain Ash, is the dread of witches, and they will go nowhere near it, as we see from the following couplet:

"Rowan-tree and red thread

Put the Witches to their speed."

A piece of rowan wood carried in the pocket acts as a charm against all ill wishes, and small branches suspended over a cow's stall and wreathed around her horns, will guard her from the effects of the evil eye, and keep her in good health, more especially if her owner does not forget to repeat regularly this prayer:

"From Witches and Wizards, and long-tailed Buzzards, And creeping things that run in hedge-bottoms,

Good Lord, deliver us!"

The witch who is touched by a branch of this tree by a christened man will be the victim carried off by the devil when he comes to claim his tribute. This tribute is alluded to in the ballad of young Tamlave:

"Oh pleasant is the fairyland, And happy there to dwell;

But aye, at every seven years' end, We pay a teind to hell."

In some of the old legends, the ash is joined with the rowan as one of the plants which hold witches and devils in dread, and it was said to resist all 
WITCHES AND THEIR FLOWER LORE IO7

attacks of witches and elves, and on this account ash-sap was administered to newly-born children, as a precaution against the fairies or witches changing the child, or even stealing it.

A bunch of ash-keys is thought as efficacious as rowan wood in some districts for warding away the witches. It was said that the ash appears without its red buds on May Day, the witches having bitten them off during the preceding night, as they went on their way to the May-Day festivities.

The Holly is another tree most obnoxious to witches. In its name they see but another form of the word "holy," and its thorny foliage and blood-red berries are suggestive to them of Christian associations, which they would rather forget.

Pliny states that if the holly be planted near a house it will keep away all malign spells and enchantments, and also defend the house from lightning. In those "good old days" of witches and potions, which might be brewed for one's enemies, there were doubtless many more herbs which went to make up the choicest receipts of the witch; but, alas, for any who should be thinking of practising such magic spells in these prosaic days, methinks the full instructions have not been handed down to us severely practical mortals. Directions have got lost in the dust of oblivion, and in the hurry and rush of modern life no time remains for anything not tangible and visible to our mortal eyes, such as fairies, gnomes, elves, goblins, witches, and wizards. Perhaps when the clock has beat its pendulum a little further round, we shall find ourselves back again in those entrancing days of spells, enchantments, and incantations. 


\section{I08 THE GLORY OF THE GARDEN}

And then for those who do not behave in a peaceable and law-abiding fashion, the punishment will not be imprisonment in a brick-walled gaol, but the offender will find himself firmly rooted to the ground, there to serve out his time as some tree or prickly shrub.

Ben Jonson, in the "Masque of Queens," speaks of the gum, or turpentine of the larch, as being used in witchcraft. A witch answers her companions thus:

"Yes, I have brought (to help your vows)

Horned Poppy, Cypress-boughs,

The Fig-tree wild, that grows on tombs, And juice that from the Larch-tree comes, The basilisk's blood and the viper's skin; And now our orgies let's begin." 


\section{CHAPTER XIII}

\section{THE DEVIL'S PLANTS}

"From his brimstone bed at break of day

A-walking the Devil is gone,

To visit his little snug farm of the earth

And see how his stock went on."

AcCording to many old countryside myths and superstitions, any plant or flower with a peculiarity of a pronounced nature, has become associated in folklore and legend, with his satanic majesty.

Scabious is known as "Devil's Bit"; this name arises, no doubt, from the shape of the root, which looks as though a piece had been bitten out. Legend says that the devil, knowing that this particular part of the root cured all diseases, out of sheer malice bit it off. To quote Gerarde, a very old authority on the subject: "The great part of the root seemeth to be bitten away; old fantasticke charmers do report that the Deville did bite it for envie, because it is an herbe that hath so many good virtues, and is so beneficial to mankind."

The fruit spikes of the wild arum, known by children as "Lords and Ladies," are in some parts of the country called the "Devil's Men and Women."

The Greater Stitchwort is known as "Devil's Corn " and also "Devil's Eyes."

The Dodder, that uncouth parasite fattening on other plants' lifeblood, is one of the most universally 
disliked plants, and is known as "Strangleweed," "Hellbind," and "Devil's Guts." Its yellow, twining, leafless stems, with the little branches of light blossoms, certainly have a very uncanny and sinister appearance.

The Puff-ball Fungus is rather appropriately named the "Devil's Snuff-box," on account of the dust or particles which they contain, these have long borne an evil name; one could quite imagine the prince of darkness putting it to such a use. Gerarde says that: "It is very dangerous for the eies, for it hath been often seene that divers have been pore-blinde ever after when some small quantity thereof hath beene blowne into their eies."

Garlic is somewhat fittingly described as "Devil's Posy," and the Irish say of this plant that if the leaves are boiled in water and this concoction used as a bath it will cure sciatica and rheumatism. Surely the patient would need a good airing after such an ablution!

There is a very curious legend relating that when Satan stepped out from the Garden of Eden after the fall of man, garlic sprang up from the spot where he placed his left foot, and onions from that which his right foot touched. And it would seem that there is something mysterious in the garlic, that it should be so thoroughly acceptable, almost indispensable, to many thousands, whilst to others it is so horribly offensive as to be practically unbearable.

According to some old writers, the garlic was possessed of every virtue, so that it had the name of "Poor Man's Treacle" (the word "treacle" 
not having its present meaning, but being the anglicised form "theriake," or heal-all).

But, on the other hand, Gerarde affirms of the garlic that "it yields to the body no nourishment at all, it engendereth naughty and sharp blood."

The Berry of the Deadly Nightshade is known as the "Devil's Berry." The plant is also called "Death's Herb," and was formerly known under the name of Dwale, the fruit being called "Dwaleberry" (torpor or trance berry), from the Danish word "dwale," meaning a trance, or dead-sleep.

The Belladonna in Bohemia is said to be a favourite plant of the devil, who watches over it. He may, however, be drawn from it on a certain night of the year by letting loose a black hen, after which he will immediately run.

In Ireland, it is said to be very unlucky to pick blackberries after Michaelmas: "At Michaelmas the devil puts his foot on the blackberries."

In Sussex, there is an old legend which fixes the date as October Io, after which time the devil goes round and spits on the fruit.

The Devil as the Power of Evil plays an important part in all European folklore. In medirval times we find him in all sorts of grotesque guises, and with very various borrowed attributes. He is the black dog in Dr. Faust's study, or, imitating the classic sylvan deity Pan, he figures as a goat, with cloven hoofs and horns. As the prince of the powers of the air, he is attended in his midnight flights by troops of witches, mounted on brooms. $\mathrm{He}$ is Wayland Smith, the cunning worker in metals, and, like Hephaistos, he is lame as the result of a fall from heaven. 


\section{2 THE GLORY OF THE GARDEN}

From the Scandinavian god Thor he obtains his red beard and his pitchfork, and probably he gets his name of "Old Nick" from his appearing as a water-imp, or "Nix."

The Mandrake is a gruesome herb, and is a dweller in the dark places of the earth. Legend says that it thrives under the shadow of the gallows, being nourished by the exhalations or flesh of the criminals executed on the gibbet.

Old writers tell us that the mandrake has the power of uttering sounds, and that when it is pulled out of the ground it shrieks and groans, and so terrible are these cries that few may hear them and live. Shakespeare speaks of them thus:

"Would curses kill, as doth the Mandrake's groans,

I would invent as bitter-searching terms, As curst, and harsh, and horrible to hear."

And Moore relates in verse another tradition:

"The phantom shapes-oh touch them notThat appal the maiden's sight,

Lurk in the fleshy Mandrake's stem

That shrieks when plucked at night."

Shakespeare tells us again of these screams and their effects:

"And shrieks like Mandrakes, torn out of the earth, That living mortals, hearing them, ran mad."

The only way to guard against these dangers, therefore, was to remove the surrounding soil and harness a dog to the plant and let him drag it out. The unfortunate animal immediately died, but the root, when obtained, will act as a familiar spirit to its owner. 
It is said that the witch-doctors made little idols of the roots, which were consulted as oracles, and their repute was such that they were manufactured in great numbers and sold in cases.

According to Pliny, the mandrake was sometimes shaped like a man, at others like a woman: the male was white and the female black.

From the earliest ages the Atropa mandragora seems to have been regarded as a mystic plant by the Eastern peoples, and thought by them to stimulate the passions, on which account it is still used for preparing love potions. It is generally believed that the mandrake is the same plant which the ancient Hebrews called "Dudaim," and that these people held it in the highest esteem in Jacob's time, is evident from the passage in Genesis (xxx. I4) of Reuben finding it, and carrying the plant to his mother Leah. From the very earliest times in the East, the mandrakes were reputed to possess the power of removing sterility; hence Rachel's desire to obtain from Leah, the plants that Reuben had found and given to his mother.

In an Anglo-Saxon manuscript of the tenth or eleventh century, the mandrake is said to shine in the night like a candle. The Arabs called it the "Devil's Candle," because of this nocturnal shining appearance, and in allusion to this peculiarity Moore speaks of it in "Lalla Rookh":

"Such rank and deadly lustre dwells,

As in those hellish fires that light

The Mandrake's charnel leaves at night."

The Elder has always been associated in plant lore and legend with all that was evil, and there is perhaps 


\section{4 THE GLORY OF THE GARDEN}

no tree round which so much contradictory folk-lore has revolved as the elder tree.

This is not surprising, as some say that it is the tree which Judas Iscariot selected whereon to hang himself after he had betrayed Our Lord. On this score one would imagine that it should be a very excellent thing to uproot it from our gardens, but not so, as to dig up an elder is said to be one of the most unlucky things that man can do.

Shakespeare, in "Love's Labour's Lost," says: "Judas was hanged on an elder," and this belief was general among early writers, and is constantly alluded to by authors of the Elizabethan period; but the name "judas tree" was given to the Cercis siliquastrum about the same period.

Gerarde, a great authority on the subject, definitely tells us of the Cercis: "This is the tree whereon Judas did hang himself, and not upon the Elder-tree, as is stated."

On the other hand, an old Eastern traveller, Sir John Mandeville, tells us that the very elder tree upon which Judas hanged himself was to be seen in his day close to the Pool of Siloe; while the legend which connects Judas with the elder is alluded to by Ben Jonson, and is thus referred to in "Piers Plowman":

\section{"Judas, he japed \\ With Jewen silver, And sithen on an Elder \\ Hanged hymselve."}

This was quite enough to give the tree a bad name, which other characteristics helped to confirm -i.e., the evil smell of its leaves, the heavy narcotic 
scent of the flowers, its hard and heartless wood, and the ugly, drooping black fungus that is almost exclusively found on the elder, vulgarly called the "Ear of Judas"- Hirneola auricula juda.

But not only is this ill-omened tree credited with being connected with the death of Judas, but there is a widespread belief that it was the "accursed tree" on which Our Lord was crucified; and therefore, in many districts, although fuel may be scarce and these sticks plentiful, the countryfolk will on no account burn them.

In Scotland, it is called the "Bour Tree," and the following rhyme instances the belief entertained in that country:

"Bour-tree, bour-tree, crooked rung,

Never straight and never strong,

Ever bush and never tree,

Since Our Lord was nailed on thee."

In Chambers's "Book of Days," we are told that a person is perfectly safe under the shelter of an elder tree during a thunderstorm, as lightning will never strike the tree of which the Cross was made.

In Napier's " Folk-Lore of the Northern Counties," there is recorded a very quaint custom. An elder tree is planted in the form of a cross upon a newly-made grave, and if it shoots forth and flowers it is a sign that the soul of the dead person is in Paradise.

In England, the elder has been regarded with superstition from the very earliest times, and looked upon as a tree of bad omen. Branches of elder were formerly considered typical of disgrace and woe. 


\section{II6 THE GLORY OF THE GARDEN}

In the "Canones editi sub Edgari Rege," it is enacted that every priest forbid the vain practices that are carried on with elder-sticks. In a rare old tract on Gloucestershire superstitions, a figure is given of an elder-wood cross, borne constantly about the person as a cure for rheumatism. This cross consisted of a small piece cut from a young shoot, just above or below a joint, so as to leave the bud projecting at each end of it, after the fashion of a rude cross. To be efficient, the elder must have been grown in consecrated ground. In Tortworth, and a few other Gloucestershire churchyards, there still exist such trees, and applications for pieces from them are still made by some of the older inhabitants of the villages.

Many trees with which the name of Judas is associated are regarded with awe, on account of their connection with the devil. In Bohemia, the willow is said to be the tree on which Judas hanged himself, whence the superstition that the devil has given it a peculiar attraction for suicides.

The following stories of his satanic majesty seem too good to miss, though they are in no wise connected with plant lore, so may be deemed irrelevant in this chapter.

This Serbian myth accounts for the bollow in the sole of man's foot:

The devil stole the sun and set it on a lance, which he left planted in the ground whilst he went bathing with an archangel. The archangel dived and brought up some sand. The devil spat on the ground, and a magpie arose from his spittle, to mount guard while the devil also dived. 
$\mathrm{He}$ was no sooner under than the archangel made the sign of the cross, and the water was frozen over: then off he flew to heaven with the impaled sun. The magpie screamed. The devil could not get out till he had sunk again in search of a stone to break the ice. He managed to overtake the archangel just as he had got one foot in heaven, and he caught hold of the other foot, and tore off a large piece of the flesh. The archangel complained to the Almighty, who decreed, in order to pacify him, that every man should henceforth have a hollow on the sole of his foot.

The final irrelevant legend concerns the story of Peacock's Feathers and Ill Luck:

When God created the peacock, the seven deadly sins gazed with envy at the splendid plumage of the bird, and complained of the injustice of the Creator. "You are quite right, I have been unjust," said the Almighty, "for I have already bestowed too much on you; the deadly sins ought to be black as night, who covers them with her veil."

And taking the yellow eye of envy, the red eye of murder, the green eye of jealousy, and so on with the rest, He placed them all on the feathers of the peacock, and gave the bird its liberty.

Away went the bird, and the sins, thus despoiled, followed close on his track, trying in vain to recover their lost eyes. This is the reason why, when a man decks himself with a peacock's feathers the sins incarnate dog his footsteps and assail him, each in its turn.

Finally, let us end this chapter of the devil with 
II 8 THE GLORY OF THE GARDEN

one more verse from " The Devil's Thoughts," by

Coleridge:

"And how then was the Devil drest?

$\mathrm{Oh}$ ! he was in his Sunday best:

His jacket was red and his breeches were blue,

And there was a hole where the tail came through." 


\section{CHAPTER XIV}

FAIRIES AND THEIR FLOWER LORE

"And lo ! upon my fixed delighted ken

Appeared the loyal Fays. Some by degrees

Crept from the primrose buds that opened then,

And some from bell-shaped blossoms like the bees,

Some from the dewy meads, and rushy leas,

Flew up like chafers when the rustics pass;

Some from the rivers, others from tall trees

Dropped like shed blossoms, silent to the grass, Spirits and elfins small, of every class."

How much poetry has left the world since Oberon and Titania

"Danced full oft in many a grene mead,"

and the cowslips were the pensioners of the Fairy Queen? In those days there was scarcely a flower in wood or on the river-bank but had its mysterious connection with the elfin world.

Hardly a tree in the greenwood, from the great oak of Thor to the elder with its white blossoms glimmering through the shade, but had its special legends and marvellous properties. Nowadays, though the flowers are as bright, and the greenwood as spreading as ever, the elf is but rarely seen.

The belief which in those old days gave life to the moorland and forest has, alas! disappeared. But it is still possible to trace their presence, not 
only by the dark rings on the sward, but by the mark set by them on many a plant and flower and in the names which still cling to them.

Underneath the characters of the fairies lie those of the old Northern deities Woden and Thor and Freyja; and, deeper still, those of the more ancient world into which they intruded-the world of Pæon, the physician of Olympus, who bestowed his name on the pæony; and of Helen of Troy, whose virtues, if not her beauty, are commemorated in the helenium, or elecampane, of which herb, says Gerarde, she had her hands full when she was carried off.

It was always a well-known fact that the fairies were passionately fond of most flowers; it is a part of their mission to give to each maturing blossom its proper hue, to guide creepers and climbing plants, and to teach young plants to move with befitting grace.

$T$ he Anemone, or wind flower, is a recognised fairy blossom. The crimson marks on its petals have been painted there by fairy hands; and in wet weather it affords shelter to benighted elves, who are glad to nestle inside the tent of fair petals, and pull the curtains around them.

Tulips are greatly loved by the fairy folk, who utilise them as cradles in which to rock the infant elves to sleep.

The Fairy Flax (Linum catharticum) is, on account of its extreme delicacy, selected by the fays as the substance to be woven for their raiment.

The Cowslip, or fairy cup, Shakespeare tells us, forms the couch of Ariel, who sings so sweetly of his fairy life: 
"Where the bee sucks, there lurk I;

In a Cowslip's bell I lie;

There I couch when owls do cry."

The tiny crimson drops in the cowslip's chalice are said to possess the virtue of preserving, or even restoring, youthful bloom and beauty; for these ruddy drops are fairy favours, and therefore have enchanted value.

To quote Shakespeare again on this flower of the Fays:

"And I serve the Fairy queen,

To dew her orbs upon the green:

The Cowslips tall her pensioners be;

In their gold coats spots you see;

Those be rubies, fairy favours:

In those freckles live their savours."

The tiny people love to nestle in the drooping bells with their crimson drops. Do you not hear soft music pealing from them when the moon shines bright and dew glitters on the grass: sweet voices too, singing the praises of that sheltering flower, wherein they can await the passing by of showers?

The hurrying of fairy crowds when rain-drops patter and begin to fall; their gossamer robes, now light, now dark, as leaf-shadows fall upon them, and their anxious, tiny faces looking wistfully through the blades of grass for some friendly cowslip. In a moment they are seen clambering up the stalks, rushing each one into the nearest bell, and then a symphony of soft, sweet voices, and he who listens may hear, perchance, a melody of fairyland.

The Foxglove is the special delight of the fairy tribe, and in some parts it is known by the name of 


\section{I22 THE GLORY OF THE GARDEN}

"Fairy Petticoats." It was said that the elves were always supposed to dress in green, but evidently that applies only to their outside apparel, and there seems no reason at all why they should not have gay petticoats. In Ireland, the foxglove is known as "Fairy Bells," and also "Fairy Gloves." Then, again, in their more serious moments, the elves are industrious enough to mend their clothes, and in the foxglove we find the fairy thimbles.

When it bends its tall stalks the foxglove is making its obeisance to the little people, or preparing to receive some small elf who wishes to hide himself in the safe retreat afforded by its accommodating bells.

On account of its connection with the fairies, the name is thought originally to have been the "Fairy, Folk's Glove," the present name of "Foxglove" being a shortened corruption.

In Ireland, the Ragwort is specially dedicated to the fairies, and just as witches delight to ride on the broom and the thorn, so the fairy gallops about at night on this golden flower.

"Her chariot is an empty hazel-nut,

Made by the joiner squirrel, or old grub, Time out of mind the fairies' coach-builder."

The Four-leaved Clover is the only plant that will enable its wearer to see the fairies; it is a magic talisman whereby to gain admittance to the fairy kingdom.

There is a Cornish fairy tale intimately associated with the four-leaved clover which runs thus: One evening a maiden set out to milk the cows later than usual; indeed, the stars had begun to shine before 
she had completed her task. Daisy (an enchanted cow) was the last to be milked, and the pail was so full that the milkmaid could hardly lift it to her head. So, to relieve herself, she gathered some handfuls of grass and clover, and spread on her head in order to carry the milk-pail more easily. But no sooner had the clover touched her head than suddenly hundreds of little people appeared, surrounding Daisy, dipping their tiny hands into the milk, and gathering it with clover flowers, which they sucked with gusto.

Daisy was standing in the long grass and clover, so some of these little creatures climbed up the stalks and held up buttercups, convolvulus, and foxgloves to catch the milk which dropped from the cow's udder. When the astonished milkmaid, upon reaching home, recounted her wonderful experiences to her mistress, the good housewife at once cried out: "Ah, you put a four-leaved clover on your head!"

Unless armed with this potent herb, the only other means available to mortals who wish to make the acquaintance of the fairies is to procure a supply of a certain precious unguent prepared according to the receipt of a celebrated alchymist, which, applied to the eyes, is said to enable anyone with a clear conscience, to behold without difficulty or danger the most elusive fairy, sprite, or gnome that he may meet at any time; this is an exact copy of the preparation of this magic physic:

"A pint of Sallet-oyle, and put it into a vialglasse; but first wash it with Rose-Water and Marygold water, the flowers to be gathered towards the East. Wash it till the oyle comes white, then 


\section{I24 THE GLORY OF THE GARDEN}

put it into the glasse 'ut supra,' and then put therein the buds of Hollyhocks, the flowers of Marygolde, the flowers of wild Thyme, the Buds of Young Hazle; and the Thyme must be gathered near the side of a hill where Fayries used to be, and take some grasse from a Fayrie throne. Then put these all with the oyle into the glasse, and sette it to dissolve three dayes in the sunne and then keep it for thy use, "ut supra." "

The Wood Sorrel, with its tiny white flowers and delicate purple veins, is called by the Welsh, "Fairy Bells," and it was said that the merry peals which call the elves to moonlight dance and revelry are sounded forth by these miniature bells:

"These be the pretty genii of the flowers,

Daintily fed with honey and pure dew-

Midsummer's phantoms in her dreaming hours,

King Oberon and all his merry crew,

The darling puppets of romance's view;

Fairies and sprites, and goblin elves we call them,

Famous for patronage of lovers true.

No harm they act, neither shall harm befall them,

So do not thus with crabbed frowns appal them."

According to the old pastoral poets, the fairies are most wont to bestir themselves soon after sunset, a time of indistinctness coupled with a sort of silent mystic charm. But it is at midnight that the whole fairy kingdom is most thoroughly alive; then it is that the faint music of the harebell is heard ringing out the call for the assembly of fairies and elves.

"'Tis the hour of the Fairy ban and spell,

The wood-tick has kept the minutes well;

He has counted them all with click and stroke,

Deep on the heart of the forest Oak. 
"And he has awakened the sentry Elve,

That sleeps with him in the haunted tree,

To bid him ring the hour of twelve,

And call the Fays to their revelry."

The fairies are very fond of riding to the trystingspot on an aerial steed: either the ragwort (the fairies' horse), or a blade of grass, a fern frond, or a straw, are some of their other methods of transit. On arrival, the merry throng make their way to some grassy bank or pasture, and their gay dance through the night, causes those dark green circles that are known to mortals as "Fairy Rings."

A Devonshire legend says that these rings are caused by the fairies catching the colts found in the fields, and riding them round and round. Michael Drayton says of this:

"They in their courses make that round,

In meadows and in marshes found,

Of them so called the fairy ground."

On these rings, rustic superstition maintains that no sheep or lamb will browse, and in Ireland, charmed home of the fays, no man would venture to set foot within these magic circles, else will he incur the dire displeasure of the "little people." Likewise, if a tree should fall athwart the fairy ring, there it must remain-it is the property of the fairies, and must on no account be moved. Disregarding the charm of many ages which lingers round this fairy superstition, and apparently quite oblivious of the poet's assertion that-

"Of old the merry elves were seen

Pacing with printless feet the dewy green," 


\section{I26 THE GLORY OF THE GARDEN}

some naturalists tell us that the phenomenon of these rings is due to lightning, others to the work of ants, and others, again, to the growth of a small fungus, Agaricus orcades. However, be that as it may, doubtless there will always be found simpleminded folk who prefer to believe that the rings are caused "by the fairies" twinkling feet."

The Peziza, a very beautiful fungus growth, which is in the form of a scarlet cup, is the "Fairies" Bath," in which they make their morning ablution, at the close of the night's festivities, whilst the dew is still heavy on grass and flower and bush.

The peziza may be found growing on pieces of broken stick, chiefly in dry ditches and hedges; it does not frequent damp or very wooded spots.

In Wales, nearly all the fungi tribe were known as "Fairy Tables."

Another fungus specially appropriated by the fairies is "Fairy Butter," Tremella arborea; it is a yellowish, gelatinous substance, found upon rotten wood or fallen timber, and, according to old countrytime beliefs, it was said to be made in the night and scattered about by the fairies.

In such esteem were the fairies or pixies held by the countryfolk of Devon and Cornwall, that in the olden days a share of the fruit crop was always set apart for them, to ensure their friendship and good offices. It was said to be most unlucky to pick up any of the "windfalls," as these were the property of the pixies, who must on no account be robbed of their due.

There are some of the fairy community known as water-nymphs, who frequent the vicinity of pools and the banks of streams and rivers, and they are 
always much concerned with, and interested in, the plant life of stream, pond, and bog.

"Say, knowest thou the Elfin people gay?

They dwell on the rivers' strand;

They spin from the moonbeams their festive garb,

With their small and lily hand."

A belief in the existence of good spirits who watched and guarded wells, springs, and streams was very common in former times.

On October 13, the Romans celebrated at the Porta Fontinalis a festival in honour of the nymphs who presided over fountains and wells; this was called the Fontinalia, and during the ceremonies wells and fountains were ornamented with garlands.

The saints and martyrs have long since taken the place of nymphs and fairies as patrons of these wells, and pilgrimages are made to many holy wells and springs in the United Kingdom, for the purpose of curing certain diseases, by the virtues contained in their waters. It should not be surprising that even in these days the fairies are fond of assembling round these wells, and dancing their rounds, lighted by the soft rays of the moon:

\section{"By wells and rills, in meadows green, We nightly dance our hey-day guise, And to our Fairy King and Queen \\ We chant our moonlight minstrelsies."}

In the historic fairy tales of Grimm, we are told that the elves are fond of inhabiting oak trees, the holes in the trunks being utilised by the fairies as a means of entry and exit.

The Esthonians believed that during a thunderstorm, and in order to escape from the lightning, 


\section{I28 THE GLORY OF THE GARDEN}

the timorous elves burrow several feet beneath the roots of the tree they inhabit.

As a rule, these forest elves are good-natured, and if they are not offended will do men a good turn whenever possible, even teaching them some of the mysteries of Nature, of which they possess the secret.

In our own country, oaks were always thought to be the favourite abode of elves, and travellers upon approaching groves, that were reputed to be haunted by them, used to think it well to turn their coats for good luck.

"Would you the Fairy regions see,

Hence to the greenwood run with me;

From Mortals safe the livelong night,

There countless feats the Fays delight."

There are some plants and trees in whose names we can still trace the influence of the elves. The Elm is often known as the "Elven," as the fairies specially delight in this tree.

It was a pretty fancy, back in the Dark Ages, which pictured to us the fairies, or " little peoples," as being very real inhabitants of the spirit world. For they were said to be the angels who remained neutral when "Michael and his angels fought against the dragon and his angels," and because they remained neutral they were cast by the Almighty out of heaven, and some fell on dry land and some fell into the sea; and these are most gentle and beautiful creatures, who will do no harm if they are left alone, and undisturbed by the presence of mortals. In fact, they would do many kindly deeds for those who thought kindly of them, and of children they took especial care. 


\section{FAIRIES AND THEIR FLOWER LORE I29}

After the Reformation, the belief in fairies in England (in common with that of angels) suffered a severe decline; in fact, it would almost seem that, in the words of Bishop Corbett, Bishop of Oxford and Norwich early in the seventeenth century, they were "banished for their religion."

"Lament, lament, old abbies,

The Fairies' lost command;

They did but change priests' babies,

But some have changed your land;

And all your children sprung from hence

Are now grown Puritans,

Who live as changelings ever since

For love of your domains.

"Witness those rings and roundelays

Of theirs, which yet remain,

Were footed, in Queen Mary's days,

On many a grassy plain;

But since of late Elizabeth,

And later James came in,

They never danced on any heath,

As when the time hath bin.

"By which we note the fairies

Were of the old profession, Their songs were Ave Marias,

Their dances were procession.

But now, alas! they all are dead,

Or gone beyond the seas;

Or farther for religion fled,

Or else they take their ease."

The Fairies' Farewell 


\section{CHAPTER XV}

\section{OUR LADY'S FLOWERS}

\section{"Mystic Rose! that precious name,}

Mary from the Church doth claim;

In the lily's silver bells,

The purity of Mary dwells.

In the myrtle's fadeless green,

Mary's constancy is seen."

IN the olden days, before men had been brought under the influence of the Reformation, we find that there were certain flowers and plants, that had been held sacred to the heathen deities of classical mythology.

The first two days of the week were set apart to the sun and moon god, Tuesday was named after Tuisco, Wednesday after Woden, Thursday after Thor, the god of War and Thunder, and Friday after Freyja.

To Freyja, as to Venus, many plants were dedicated, and all these were quite naturally transferred to the patronage of Our Lady. The ladybird was once Freyja's own insect, and Orion's Belt, which in Sweden is still called Freyja's spindle, belongs to Mary.

The Holy Virgin is our Rose of Sharon and Lily of the Valley; and the poetry, no less than the piety of Europe, has inscribed to her the whole bloom and colouring of the fields and hedges.

The choicest flowers were wrested from the classic 
Juno, Venus, and Diana, and from the Scandinavian Bertha and Freyja, and bestowed upon the Madonna, whilst floral offerings of every sort were laid upon her shrines.

In her own month of May does not all Nature rejoice with Mary? All the woods are carpeted with bluebells, who continually and softly ring the "Mary-Bell," did we but listen and understand.

The horse chestnuts, most imposing of trees, put up innumerable votive candles of pink and white, all in honour of Mary, during her own month of May. And, strange fact, throughout the countryside there is a wealth of blue flowers, Our Lady's own colour.

" The happy birds $\mathcal{T}_{e}$ Deums sing, 'Tis Mary's month of May;

Her smile turns winter into spring, And darkness into day.

And there's a fragrance in the air, The bells their music make, And oh ! the world is bright and fair, And all for Mary's sake."

A Catholic writer has recently complained that at the Reformation "the very names of plants were changed in order to divert men's minds from the least recollection of Christian piety; and a Protestant writer of the eighteenth century, bewailing the ruthless action of the Puritans in giving to the "Queen of Beauty" flowers named after the "Queen of Heaven," says: "Botany, which in ancient times was full of the Blessed Virgin Mary, is now as full of the heathen Venus."

The snowdrop is the Fair Maid of February, as being sacred to the Purification, or Candlemas 


\section{THE GLORY OF THE GARDEN}

(February 2), when her image was removed from the altar and snowdrops strewed in its place.

To the Madonna, in her capacity of Queen of Heaven, were dedicated the almond, the white iris, the white lily, and the narcissus, all appropriate to the Annunciation (March 25).

The lily, and white and red roses, were assigned to the Visitation (July 2), flowers typical of the love and purity of the Virgin Mother.

To the Feast of the Assumption (August 15) is assigned the Virgin's Bower (Clematis flammula), and to Our Lady's Birthday (September 8) the amellus (Aster amellus), and to the Conception (December 8) the Arbor vite. The Rosary of the Blessed Virgin, instituted by St. Dominic, was so called as the beads were formerly made of roseleaves tightly pressed into round moulds, where real roses were not strung together, and thus the entire chaplet was called a rosary.

The use of the rose, during Our Lady's own month of May, is in Italy a national custom. Everyone has roses in the oratory or on the table all the month through. "As an emblem of the Virgin, the rose, both white and red, appears at a very early period, and it was especially so recognised by St. Dominic, when he instituted the devotion of the Rosary. The prayers appear to have been symbolised as roses."

There is a story of " a lordsman who had collected much goods of his lord's, and who had to pass with his treasure through a wood, in which thieves were waiting for him. When he entered the wood he remembered that he had not that day said 'Our Lady's Saulter,' and as he knelt to do so the 
Holy Virgin came and placed a garland on his head, and at each Ave she set a rose in the garland that was so bright that all the wood shone thereof."

He was himself ignorant of it, but the thieves saw the vision, and allowed him to pass unharmed.

The Rose of Jericho has been called "Mary's Rose," and tradition affirms that when Joseph and Mary were fleeing into Egypt, one of these flowers sprang up to mark every spot where they rested.

Tradition says that the clematis owes its name of "Virgin's Bower" to the fact that several times this plant afforded Our Lady grateful shade and shelter during the flight into Egypt.

"When Mary left us here belowe

The Virgin's Bower was full in blowe."

A legend of Tuscan origin condemns the broom as a traitor. For as Our Lady, with the Holy Child in her arms, was crossing an exposed pathway, fearful of being seen by Herod's soldiers, she sought refuge among the brushwood.

But as she stooped for shelter the broom and the chickpeas set up such a crackling and rustling that they must have betrayed her if she had not observed a juniper, who immediately opened its friendly branches, closing them again at once upon the Holy Mother and Child, thus affording them sure concealment and protection.

A legend of the rosemary, not so well known as many other plant legends, tells us how the plant came by its blue flowers. It is said that Our Lady threw her linen over a white-flowered shrub to 


\section{I34 THE GLORY OF THE GARDEN}

bleach it, and ever after the flowers were as blue as Mary's robe.

"What flower is that which royal honour craves, Adjoins the Virgin, and 'tis strewn on graves ?"

The Legend of the Iris, or Fleur-de-Lys.

There was once a knight, more devout than learned, who could never remember more than the two first Latin words of the "Ave Maria."

And in these words he continually addressed his prayer to Heaven. Night and day his supplication continued, until at last the good old man died, and was buried in the chapel-yard of the convent, where, as a proof of the acceptance of his brief but earnest prayer, a plant of fleur-de-lys sprang up on his grave, which displayed on every flower, in golden letters, the words "Ave Maria."

This strange sight induced the monks, who had despised him during his lifetime for his ignorance, to open his grave. On doing so, they found that the root of the plant rested on the lips of the holy knight.

An antiquarian writes: "How soon flowers were used for ecclesiastical purposes in England it is difficult, nay, impossible, to say. We know that gardens were devoted to the special cultivation of flowers for the churches. There was one, for instance, adjoining the Lady Chapel at Winchester, and the spot, for a long time after the destruction of the sacristy, went by the name of 'Paradise." "

Henry VI., in his will, left particular directions concerning a garden for the church of Eton College, "which is left for to sett in certain trees and flowers, 
behovable and convenient for the service of the same church."

We read that William, Abbot of St. Albans (A.D. I2I4-35), appointed that "the wax taper, which we are accustomed to wreathe about with flowers, should be burnt before the beautiful image of Mary, carved by William of Colchester, both day and night on the principal feasts, and during the procession which is held in honour of the Blessed Virgin."

The Lily, though not indigenous to Palestine, was early known both in Syria and in Egypt, and so it may quite likely be that the lily work which figured so largely in the ornamentation of Solomon's Temple, was modelled from Lilium candidum. As typical of purity and majesty, the Greeks dedicated it to Hera, the sky-mother; so it was quite a natural transition in the very early days of Christianity for the lily to be given to Mary, emblem of moral beauty and purity.

"From Visitation to St. Swithin's showers, The Lily white reigns Queen of Flowers."

The Italian Masters portray Our Lady always with a spray of lilies, and also St. Joseph, on account of his staff having blossomed and brought forth a lily. At the Annunciation, the angel Gabriel carries in his hand a branch of the Madonna lily.

Tradition tells us that St. Thomas refused to believe in the bodily assumption of Our Lady into heaven, and desired that her tomb should be opened. This was done, whereupon it was found to be full only of a wealth of lilies and roses.

In 1048, the Order of Knights of St. Mary of the 


\section{THE GLORY OF THE GARDEN}

Lily was instituted by Garcius, fourth King of Navarre.

The Milk Thistle (Carduus marianus) takes its name from Mary, and was known as "Our Lady's Thistle." It owes its name to the white veins upon its leaves, for which legend accounts thus: One day Our Lady, tired from a long ride, seats herself beneath a hawthorn, and proceeds to feed the Holy Child. Soon the Holy Mother slumbers, and the Divine Babe, refreshed, sinks sweetly asleep also, and some drops of the milk thus escape, and trickle down upon a thistle growing by the Madonna's side. And it is the imprint of this accident upon its leaves that gives to $C$. marianus the white marks that distinguish the plant.

An Order of the Thistle, called the Order of Bourbon, was instituted in France in 1370, in honour of Our Lady.

The Iris, owing to its brilliant hues, the Greeks named after the rainbow, symbol of light and hope.

To Juno, Queen of Heaven, the iris was dedicated, and was regarded as symbolical of eloquence and light. From her, in Christian times, the iris passed to Our Lady, to whom the white species more especially is dedicated.

In "Flower Lore and Legend," the Reverend Hilderic Friend gives us an interesting summary of Our Lady's flowers. In chapter iii., "The Virgin's Bower," he says: "How liberal we have been towards Her Ladyship will appear when I enumerate some of the plants with which She is honoured. Thus, as She reclines in Her.bower, we provide Her with boots and slippers for Her feet, 
garters with which to keep Her hose in place, and laces for Her shoes. We have found Her a thimble and needle with which to sew, a smock and a mantle in which to garb Herself, a cushion on which to recline, and a comb and looking-glass for Her hair. Having done all this, we plant around Her bower trees, grass, whin, clover, cowslip, mint, bracken, foxgloves, fern and thistles to make Her garden gay." This is a brief summary of the more common plants dedicated to the Holy Virgin, or bearing her name:

Lady's Smocks

Our Lady's Mantle

Ribbons

Laces ..

Nightcap

Thimbles

Tresses

Bedstraw

Cushion

Candlesticks

Tapers

Slippers
Wild Convolvulus, Meadow Cress, and Cuckoo Flower.

.. Ipomœa.

.. Ribbon Grass.

. Dodder.

. Canterbury Bells.

. Campanula.

.. Quaking Grass.

.. Galium verum.

. Armeria (Thrift).

. Oxlip.

.. Mullein.

. Cypripedium.

The dodder, although in some parts of the country exclusively regarded as an evil plant, in other districts is dedicated to Mary, under the name of " Our Lady's Laces."

In Mexico, the ipomoa grows so profusely that its azure blossoms are 5 to 6 inches across, and set so closely together that hardly a leaf can be seen. The whole plant resembles a blue cloak, and thus its name: "Manto de la Virgin."

The marigold, according to an old tradition, was 


\section{I38 THE GLORY OF THE GARDEN}

so called because Our Lady wore the flower in her bosom.

"What flower is that which bears the Virgin's name, The richest metal joinèd with the same?"

A very ancient legend records that, before the birth of Our Lord, Our Lady longed extremely to quench her thirst with some cherries which hung high above her head; so she asked St. Joseph to pick them. He, however, is reputed to have replied: "Let the father of thy child present thee with the cherries if he will." No sooner had these words escaped his lips than, as if in reproof, the branch of the cherry tree bowed spontaneously to the Holy Virgin, and she gathered the fruit and ate it. Hence the cherry is dedicated to Our Lady.

The flowering almond has always been dedicated to Our Lady, as Queen of Heaven.

Among the Hebrews, the almond tree was regarded as the symbol of haste and vigilance, because of the suddenness of its flowering, which announced the spring.

The Cedar of Lebanon, because of its height, its incorruptible substance, and its healing virtues, is by Catholics regarded as a symbol of Our Lady, expressing her greatness, her beauty, and her goodness.

The Jews evidently considered the cedar a sacred tree, and hence it was used in the making of idols.

"Wild and waste lay our desolate garden,

Stripped of blossom and leaf and fruit.

Lo! at last in the golden Autumn

Sprang the Lily from Jesse's root.

Hope and Beauty came back to Earth

Once again in Our Lady's birth." 


\section{CHAPTER XVI}

\section{FLOWERS OF THE SAINTS}

"The Snowdrop, in purest white arraie,

First rears her hedde on Candlemas daie;

While the Crocus hastens to the shrine

Of primrose love on St. Valentine.

Then comes the Daffodil beside

Our Lady's Smock at our Ladye-tide.

Aboute St. George, when blue is worn,

The blue Harebells the fields adorn;

Against the day of Holie Crosse,

The Crowfoot gilds the flowrie grasse.

When St. Barnabie bright smiles night and daie

Poor ragged Robin blooms in the haie.

The Scarlet Lychnis, the garden's pride,

Flames at St. John the Baptist's tide.

From Visitation to St. Swithen's Showers,

The Lilie white reigns Queen of the flowers;

And Poppies, a sanguine mantle spread

For the blood of the Dragon St. Margaret shed.

Then under the wanton Rose, agen,

That blushes for penitent Magdalen,

Till Lammas Daie, called August's wheel,

When the long Corn smells of Camamile.

When Mary left us here belowe,

The Virgin's Bower is fulle in blowe;

And yet anon, the full Sunflower blewe,

And became a starre for Bartholomew.

The Passion-floure long has blowed,

To betokene us signs of the Holy Roode.

The Michaelmas Daisies, among dede weeds,

Blooms for St. Michael's valorous deeds;

And seems the last of flowers that stode,

Till the feste of St. Simon and St. Jude. 
140. THE GLORY OF THE GARDEN

Save Mushrooms, and the Fungus race,

That grow til All-Hallow-tide takes place. Soon the Evergreen Laurel alone is greene,

When Catherine crowns all learned menne.

Then Ivie and Holly Berries are seene,

And Yule Log and Wassaill come round agen."

IN a little book entitled "Flowers and Festivals," the author writes: "In the ancient calendars nearly every day in the year was dedicated to some saint, who had his own legend and emblem.

"Flowers have, from the earliest times, been connected with the great festivals of the Church, or with the saints of the calendar. It is worthy of observation that the flowers dedicated to, or connected with the name of certain saints, are generally in blossom at or near the time of their festivals."

The feeling which inspired this identification of flowers and herbs with the saints and their festivals, is gracefully expressed by a Franciscan in the following passage:

"Mindful of the Festivals which our Church prescribes, I have sought to make these objects of floral nature the timepieces of my religious calendar, and the mementoes of the hastening period of my mortality. Thus I can light the taper to our Virgin Mother on the blowing of the white Snowdrop, which opens its flower at the time of Candlemas; the Lady's Smock and the Daffodil remind me of the Annunciation; the blue Harebell, of the Festival of St. George; the Ranunculus, of the Invention of the Cross; the scarlet Lychnis, of St. John the Baptist's Day; the white Lily, of the Visitation of Our Lady; and the Virgin's Bower, 
of the Assumption; and Michaelmas, Martinmas, and Holy Rood, and Christmas have all their appropriate decorations."

St. Joseph has allotted to him a white campanula, which is known in Bologna as the "Little Staff of St. Joseph." In Tuscany, the name of St. Joseph's Staff is given to the oleander. Legend recounts that St. Joseph possessed originally only an ordinary staff, but that when the angel announced to him that he was to be the husband of the Holy Virgin, he became so radiant with joy that his very staff flowered in his hand.

Another legend says that St. Joseph's staff blossomed and brought forth lilies. $\mathrm{He}$ is always portrayed in statues and pictures with a spray of lilies, emblematic of his chastity.

St. Benedict's herbs are the avens, the hemlock, and the valerian, which were assigned to him as being antidotes; a legend of St. Benedict relating that upon his blessing a cup of poisoned wine, which a monk had presented to him with evil intention, the glass was immediately broken to pieces.

St. Christopher has given his name to the royal fern (Osmunda regalis); according to Parkinson, in the sixteenth century this fern always went by the name of "Herb Christopher," or St. Christopher's Herb. The idea probably originated on account of the fern growing along riversides, such as St. Christopher was in the habit of frequenting when he acted as ferry. Hence the connection between the saint of the river and the fern of the river.

St. George has numerous plants dedicated to him or named after him. In England, his flower is the harebell, but abroad, the pæony is generally named 


\section{I42 THE GLORY OF THE GARDEN}

after him. His name is also bestowed on the Lilium convallium.

The herb of St. George is the Valeriana sativa; his root, Dentaria major; his violet, Leucoium luteum; and his fruit Cucumis agrestis.

Senecio Jacobcea is the St. James' wort, used in veterinary practice, as St. James is the patron saint of horses and colts.

The cowslip is dedicated to St. Peter, from its resemblance to his emblem, a bunch of keys. Among the old Sicilian legends there is a very curious one about the mother of the holy Apostle St. Peter, in which she is portrayed as being very mean and niggardly. The only thing that she ever gave away was a leek leaf, which she flung to a beggar who worried her one day as she was washing her pots and pans. When she died, it is said that hell received her. Years afterwards St. Peter, the doorkeeper of Paradise, heard a piteous voice saying: "Son Peter, see what torments I am in; go and ask the Lord to let me out." So St. Peter went and asked. But the Lord said: "She never did a nailparing of good. Except this leek leaf, she never once gave a scrap away. However, here is a leek leaf: this angel shall take it, and shall tell her to lay hold of the other end while he pulls her up."

So St. Peter's mother grasped the leek leaf, but all the souls in torment ran after her, and clung to her skirts, so that the angel was dragging along quite a string of them. Her evil disposition, however, would not permit her to keep quiet. It grieved her avaricious temperament that anyone besides herself should be saved; so she struggled and kicked in order to shake the poor souls off, and 
in so doing tore the saving leek leaf and fell back again, and sank deeper than before.

The daisy, as Herb Margaret, is popularly supposed to be dedicated to "Margaret that was so meek and mild."

The poppy also belongs to St. Margaret, as legend tells us that poppies sprang from the blood of the dragon slain by St. Margaret:

"And poppies a sanguine mantle spread

For the blood of the dragon St. Margaret shed."

Nigella Damascena (Love-in-a-mist), whose inflorescence spreads out rather like the spokes of a wheel, was called St. Katharine's flower, after St. Katharine, who suffered martyrdom on a wheel.

Angelica archangelica was said to have had its virtues revealed by an angel in a dream. It is specially under the patronage of St. Michael, and, as may be imagined, it is particularly useful as a protection against evil spirits.

The name of canterbury bells was given to the campanula in honour of St. Thomas of England, and in allusion probably to the horse-bells of the pilgrims to his shrine.

To St. Agnes the Christmas rose, with its delicate white flowers, was dedicated, and most appropriately, since she is the patron of purity.

Of St. John the Baptist, and the miraculous flowers of midsummer dedicated to him, much has already been written in Chapters IV. and XI. The scarlet lychnis used to be called the "Great Candlestick" (Candelabrum ingens), and was said to be lighted up for St. John the Baptist, who "was a burning and a shining light." 


\section{I44 THE GLORY OF THE GARDEN}

The legend of the Glastonbury Thorn should be well known to all those interested in flower lore:

After Our Lord's Resurrection, the friends of St. Joseph of Arimathea urged him to go to another land, for they were afraid that his life would be in danger by reason of the hatred that the Jews bore him. So St. Joseph set sail, taking with him eleven brethren, to journey to other lands, and tell the people about Our Blessed Lord. As they journeyed they were greatly tossed and buffeted by the waves, and came through many perils, till they were guided to that fair spot in the West of England which men call the Isle of Apples, or "Inis Avallon," because fruit was growing wild everywhere in the rich soil. This isle, though now surrounded by dry land, was once a true island, and another name for it was the "Island of the Blessed."

Here it was that, after weary journeyings, the steps of St. Joseph and his companions were stayed.

They landed at the northern side of a hill, which is called "Weary All Hill," because St. Joseph and his followers were so tired that they sat down to rest there. But first, St. Joseph bade them all fall on their knees to give thanks to God for having led them to such a pleasant land after all the perils they had gone through. And St. Joseph, after a little time, looking at the wondrous beauty of the fields and flowers, started chanting: "Benedicite omnia opera," and the brethren all joined in, when, lo, as they reached the verse "Oh all ye green things upon the earth, bless ye the Lord," the dry hawthorn staff which St. Joseph had stuck into the ground began to bud, putting forth tender green shoots. And as they sang, the green buds grew and 
lengthened till, with the ending of the canticle, the little staff was covered with fresh green leaves, as though it had donned its sweet spring clothing to welcome the holy men. And near this spot St. Joseph built a church, known in after days as the Abbey of Glastonbury. There St. Dunstan was born and bred, and there, so tradition says, St. Patrick and St. David were buried, and many another holy man who had been taught St. Joseph's faith, until the end came in the reign of Henry VIII., when the last abbot was cruelly done to death, and the abbey was no more used for the service of God. But the holy thorn which took root at St. Joseph's landing, flowers on the day of the Nativity. At Christmas-time, when most other flowers and trees are fast asleep, this thorn tree blossoms as though there were no cold winds and bitter frosts, and during each month of the year it will be found that the tree is never bereft of flowers.

Archdeacon Holmes, in that most charming little book "In Praise of Legend," says: "Legend appeals to something within us-something which we want and have a right to; something which comes under the law of supply and demand; something that appeals to the sense of the lovely which exists in nearly everybody. For there is something in most of us which can never be really satisfied with L.S.D., which needs something more than iron safes and well-bound ledgers, which is unsatisfied with cold grey of abstract doctrine or dogma, however essential such doctrine and storm-proof dogma may be.

"What is this something? It is the love of the lovely. And legend, and all that is lovely in legend, contributes its quota to satisfying the demand. 


\section{I46 THE GLORY OF THE GARDEN}

And notice! This love of legend is both racial and individual.

"Every nation has its legends mixed up with, and branching off into, traditions, fairy tales, fables, myths, romances. As there are the Roman fabulæ or fables, and Greek myths, and Arabian nights, so there are the old sagas, saws, or sayings, which play so large a part in our legendary past, and have their root in a God-given love of legend. No literature would be complete without its legends, for any literature which omits an element in an appeal to the imaginative faculties ceases to provide for a real want in its best students."

" The cup, the cup itself, from which Our Lord

Drank at the last sad supper with his own.

This, from the blessed land of Aromat-

After the day of darkness, when the dead Went wandering o'er Moriah - the good saint

Arimathæan Joseph, journeying brought To Glastonbury, where the winter thorn

Blossoms at Christmas, mindful of Our Lord. And there awhile it bode; and if a man

Could touch or see it, he was heal'd at once, By faith, of all his ills. But then the times

Grew to such evil that the holy cup Was caught away to Heaven, and disappear'd."

Tennyson: The Holy Grail. 


\section{CHAPTER XVII}

FLOWER LEGENDS OF "SAINTLY FAME"

"The Lord God planted a garden

In the first white days of the world;

And set there an angel warden.

In garments of light unfurled.

"So near to the peace of heaven,

That the hawk might nest with the wren;

For there in the cool of the even

God walked with the first of men."

The Legend of the Rose, and how She came BY HER THORNS.

Everyone is familiar with the old saying: "There is no rose without a thorn," but, according to ancient mythology, in its primitive state the rose was thornless, a belief which Milton must have come across, for when writing of the flowers in the Garden of Eden he says: "Flowers of all hue, and without thorn the rose."

According to an old Greek fable, the rose is supposed to have been thornless, until one unfortunate day when Cupid was smelling a newly-opened bud, and a bee, who was busily engaged in the flower, stung him angrily on the lip for his interference.

Cupid ran weeping to his mother, who, to pacify him, strung his bow with bees, first removing from 


\section{I48 T IL GLORY UF THE GARDEN}

them the stings, which she placed upon the stems of $t_{Z}-\mathrm{S}$ Sffending rose.

Zoroaster, apostle of the Persians, states that the rose was thornless until the entrance into the world of Ahriman, the spirit of evil, from which belief springs the legend that when Satan fell from heaven the idea occurred to him to make the thorns of the briar rose serve as a ladder to reascend to the celestial heights. But God would not permit the briar to continue its upward growth; He told it to grow breadthways, and because the rose obeyed the Divine command, Satan was exceedingly angry, and lowered the points of the thorns towards the earth, so that ever since then the thorns of the briar point downwards.

\section{The Legend of the Moss Rose.}

Tradition tells us that one of the angels, whose work it was to minister to the needs of erring earth inhabitants, was one evening just about to return to heaven, but so stormy and overcast was the sky, that he returned to seek shelter at one of those houses which he had blessed with his silent ministrations.

But everywhere the door was closed, and at last, tired out and feeling rather sore at heart, the angel passes wearily down the village street, and a young red rose sweetly opens to him her fragrant petals.

And there in her heart the angel sleeps, warmly sheltered from the storm; and when he wakes and sees how altogether lovely is this flower, and that he can in no wise enhance her beauty of shape or colouring, he throws over her a delicate green veil, 


\section{LEGENDS OF "SAINTLY FAME"}

making Rosa muscosa one of the sweetest and daintiest of all flowers.

"A veil of moss the angel throws, And, robed in nature's simplest weed,

Could there a flower that rose exceed?"

The rose for many years seems to have been selected by the Catholic Church as her particular emblem, and is pre-eminently Our Lady's flower, her children in all ages delighting to refer to her as Rosa mystica, and the Rose of Sharon, and the Lily of the Valley:

The rose is also said to be the "flower of the field" spoken of in the Psalms, an expression which has been taken to mean the flower of all flowers, symbolical of the Church.

\section{The Legend of the Snowdrop.}

Amongst the old books of plant lore there is an interesting account of the origin of the Snowdrop.

One day, after the Fall, Eve sat weeping for the beauties of lost Paradise and the many lovely flowers she had tended there, and as she wept and meditated thus, an angel was sent on the earth to comfort her. Now since the Fall no flower had grown on the earth, but incessantly the snow fell, and as the angel sweetly talked with Eve he caught a passing flake and breathed on it, and forthwith there fell to earth a beauteous, fragile flower.

"And lo! where last his wings have swept the snow, A quaintly-fashioned ring of milk-white snowdrops blow."

Another very old legend accounts for the origin of the snowdrop in quite a different way: At the 
Creation, when all things were coloured, the sky blue, the clouds grey, the earth brown, the trees green, and the flowers all sorts of different colours, the snow approached the Almighty, and complained that for him no colour remained, and that therefore he would be as little noticed as the wind or the rain.

The Almighty told him to go to the richly-dowered flowers and ask from them a colour. So he began with the rose, but there was no flower that would consent to share with the snow her beautiful colouring, and drearily he was about to retire, when the humble snowdrop sweetly said: "If my white colour is of any use to you, you are very welcome to it."

And that is why the snow guards and cherishes this generous and charming little flower, and keeps it warm all through the bleakest of the winter months.

\section{The Legend of the Cowslip.}

"The cowslip bending with golden bells,

Each glad hour's ending with sweet chime tells."

All through the South of Europe there is no more popular wild flower than the dainty cowslip, of most fragrant fame.

In former days it used to be known by the name of Herb Peter, or St. Peter's Herb, the name arising doubtless from the resemblance of the clustered blossoms to a bunch of keys, St. Peter's emblem.

But apart from this, there is a very old legend, connecting this humble little flower with the great saint thus:

One day St. Peter heard a rumour in heaven that people were contriving to gain admission by a back 
came one day to worship the Christ-child as He lay in His manger-throne. And as she kneels there, suddenly her eyes fill with tears, and a great sadness weighs down her heart, as she realises that she has no present to give the Holy Babe.

Then St. Gabriel appears, and speaks to the little maid:

" 'Tell me, my little one-Why do you weep?

Is it because He's so fast asleep?

See ! I will wake Him,' and Gabriel smiled,

As he kissed the face of the heavenly Child."

But the little girl amidst her tears explains to St. Gabriel that it is because she has no gift for the Holy Child, not even a few flowers.

"Then Gabriel answered, "Come, child, with me,

The flowers you wish for you soon shall see ';

And he led her forth to a place most fair,

Where sweet blossoms scented the sunlit air.

"She smiled to the angel in glad delight,

And filled her hands with the blossoms white;

Then ran with her burden of roses sweet,

And laid them all down at the Christ-child's feet."

Flower Legends of the Passion.

In Chapter XV. a Sicilian legend is recorded which condemns the broom as a traitor, and sad to say there is another legend which associates the broom with the Passion of Our Lord, and again it plays the traitor's part.

This legend tells us that as $\mathrm{He}$ was praying in the Garden of Gethsemane a broom bush which was growing near started to make such a crackling noise 


\section{I56 THE GLORY OF THE GARDEN}

that it at once attracted the attention of those who sought Him.

Whereupon He turned reproachful eyes upon the treacherous shrub, and said to it: "Mayst thou always make as much noise when thou art being burned."

The Legene of the Crown Imperial Lily.

The story of this beautiful and stately plant does not redound to its credit, yet we cannot well leave it out on that account.

Ancient legend tells us that the flower was originally white and erect, and grew in its full beauty in the Garden of Gethsemane, where it was often noticed and admired by Our Lord.

But in the night of His Agony, as He passed through the garden, all the other flowers bowed their heads in sorrowful adoration; the Crown Imperial alone remained with its head unbowed, but not for long. Sorrow and shame took the place of pride, she bent her proud head, and blushes of shame and tears of sorrow soon followed, and so she has ever continued, with bent head, blushing colour, and ever-flowing tears.

"Bent down with penitence that flower appears, And each gold cup is freighted with her tears."

It is a fact that in the bottom of each of the bells there are six drops of clear and shining water, and how these drops are formed or what service they occupy in the economy of the plant, science has not been able to tell us-the explanation evidently lies in the Crown Imperial's early history. 


\section{CHAPTER XVIII}

\section{LEGENDS OF NATIONAL FLOWERS}

\section{The Rose, National Flower of England.}

"If Zeus chose us a king of the flowers in his mirth,

He would call to the rose, and would royally crown it;

For the rose, ho! the rose, is the grace of the earth,

Is the light of the plants that are growing upon it;

For the rose, ho! the rose, is the eye of the flowers,

Is the blush of the meadows that feel themselves fair,

Is the lightning of beauty that strikes through the bowers

On pale lovers who sit in the glow unaware.

Ho, the rose breathes of love! ho, the rose lifts the cup

To the red lips of Cypris invoked for a guest !

Ho, the rose, having curled its sweet leaves for the world,

Takes delight in the motion its petals keep up,

As they laugh to the wind as it laughs from the west!"

SAPPHO.

THE rose has for many years held undisputed sway as the emblematic flower of England, and historically this fact seems to have originated at the time of the Wars of the Roses, during the reign of Henry VI.

Now, the House of Lancaster wore as its badge the Red Rose, or the "Rose Gule," and the House of York wore the White Rose, or the "Rose Argent."

When they went into battle the soldiers all wore either a red or white rose as an emblem in their caps. There is a tradition that at the time when Henry's marriage united the contending houses, a rose with white and red flowers first blossomed, 


\section{I60 THE GLORY OF THE GARDEN}

showing that the two opposing forces were now blended, and this rose was called the "York and Lancaster."

There was, says the tradition, then growing in the garden of a certain monastery in Wiltshire one particular rose-bush, which, during the troubles of the land, had, to the amazement of all, borne at once roses red and white. At the time of the marriage of Henry and Elizabeth, all its flowers blossomed forth with petals of red and white mixed in stripes. People came, as may be imagined, from all over the country to see this wonder, and hailed it as a joyful omen of future peace and harmony.

But it seems probable that the symbolism connecting the rose with England has a much earlier date, so remote as to have been mislaid in the dim and shadowy recesses of the past. For we find Pliny doubting whether the name Albion referred to the white cliffs of our Island, or to the white roses which grew there in such abundance.

Through many centuries the rose has been justly regarded as the queen of all flowers, and symbolical of all that is loveliest, brightest, and best upon the earth. Gerarde, the old herbalist, enumerated a long list of the virtues of the rose, which includes: "Strengtheninge of the hearte, and refreshinge of the spirites," and he declares that the rose gives sleep to the fevered, allays inflammation, and strengthens the inside, that it forms an ingredient in "Alle manner of counterpoysons," that, mixed with honey, it heals wounds and stanches bleeding; and, in short, that it is generally "profitable for other griefes," including the ague, "and availing the surgeon greatly to carry store thereof "; besides 
the possibility of perfectly maintaining the health by a morning diet of a salad of rose-leaves.

Pliny mentions briar-rose root as a cure for hydrophobia, and affirms that men derived their knowledge of it from a dream, of which he tells the story.

With all these visible graces and invisible virtues, is it any wonder that the rose of all flowers is the queen, and reigns supreme as our national flower and emblem?

Ancient fable tells us that the rose was dedicated to Venus, under the supposition that when Minerva sprang from the brain of Jupiter, and Venus simultaneously rose from the waves, the earth brought forth this flower, so much more beautiful than anything that had been before produced, to celebrate the double birth; and therefore, says Gerarde, " the Easterns can by no means endure to see the leaves of roses fall to the ground."

The original rose was supposed to have been white, and, the fable continues, the first red rose was that upon whose thorns Venus trod, when flying to succour the wounded Adonis.

A more beautiful legend is that related by Sir John Mandeville, who tells us that the rose never existed at all in the Garden of Eden, and that the first of the species ever seen, sprang up in a field called Floridus, on the eastern side of Ephrata. For there a fair maid, unjustly accused, had been condemned to be burnt; when, on the faggots being lighted, she prayed aloud that God would, "as truly as she was not guilty," make it known to all. At the conclusion of her prayer she walked, in the full confidence of innocence, into the midst of the burning pile; upon which the raging fire 


\section{I62 THE GLORY OF THE GARDEN}

was immediately extinguished, and the faggots as suddenly turned to roses; those which were flaming became red roses, while such as were not yet kindled, appeared as white ones.

"The lily is all in white, like a saint,

And so is no mate for me;

And the daisy's cheek is tipped with a blush,

She is of such low degree;

Jasmine is sweet, and has many loves,

And the broom's betrothed to the bee;

But I will plight with the dainty rose,

For fairest of all is she."

Thomas Hood.

\section{The Thistle, National Flower of Scotland. \\ "Proud thistle, emblem dear to Scotland's sons, \\ Begirt with threatening points, strong in defence, Unwilling to assault."}

The Thistle of Scotland is believed to be the Onopordon acantbium, the cotton thistle, which grows by the highway; this is the national insignia, and its flower-cup and bristling leaves accord well with the motto: "Nemo me impune lacessit."

Tradition says that the thistle, with the motto rendered in homely Scotch, "Who daur meddle wi' me," was adopted as the symbol of Scotland from the following circumstance:

A party of invading Danes attempted to surprise the Scots army. Now the Danes held it to be unwarriorlike to attack an enemy by night, but on this occasion they departed from their rule; noiselessly, under cover of the dark, they crept towards the camp, when one of the soldiers trod on a thistle with his naked foot, and his cry of pain roused the Scots, 
who flew to arms and drove back the foe. Thus "the guardian thistle to the foeman stern" was chosen as the cognisance of Scotland, and is regarded as the symbol of independence and retaliation. It is dear to the Scotsman more than all other flowers, "excepting the rose, and he is the rose's husband."

The thistle has given its title to a Scotch order of knighthood, which is said to have been instituted by Achaius, King of the Scots, when he obtained a victory over Athelstan. The insignia borne by the Knights of the Order of the Thistle is a gold collar, with thistles and a sprig of rue interlaced. A gold medal is also worn, bearing a figure of St. Andrew.

According to ancient mythology, the thistle is a lightning plant, and as such is dedicated to Thor, god of war and thunder, so, in common with other plants of the same nature, the thistle protects from evil. Like the classic crane, the thistle discovers and brings home crime to the perpetrator.

An old legend says that in a certain wild spot, where once a murder was committed, every day at noon there grows a strangely-formed thistle, and on this weird plant can be distinctly seen human heads, arms, and hands. When twelve heads have appeared the ghastly plant mysteriously vanishes.

"In Scotland blooms a warlike flower, Too rough to bloom in lady's bower! His crest, when high, the soldier bears, And spurs the courser on his spears, Oh ! there it blossoms, there it blows, The thistle's grown aboon the Rose!" 


\section{I64 THE GLORY OF THE GARDEN}

The Shamrock, National Flower of Ireland.

" $O$ the Shamrock, the green, immortal Shamrock !

Chosen leaf

Of bard and chief,

Old Erin's native Shamrock !"

MOORE.

The shamrock, or trefoil in history, is the badge of the kingdom of Ireland, and St. Patrick, the patron saint of that isle, is represented in the habit of a bishop holding a trefoil-St. Patrick's Cross, as it is often called by Irishmen.

Tradition tells us that St. Patrick was conducting a mission in Ireland, and one day he made the doctrine of the Holy Trinity the subject of his discourse. His hearers were quite unable to grasp this, until he plucked the leaf of a shamrock and used it as an illustration. So easy and simple was this application that their difficulties were removed immediately, and they accepted Christianity.

The actual place where St. Patrick was preaching, and from whence he picked the historic shamrock, was said to be 'Tara's Hill, near Dublin, the stronghold of paganism. This was the same occasion on which St. Patrick inaugurated the coming of Easter, by kindling the Paschal fire on Tara's Hill. The pagans, across the plain, on the hills opposite, were also keeping that night, their heathen festival of the sun.

All fires on this night, were forbidden until the sacred fire on the Hill of Tara was lit by them. When, therefore, St. Patrick's Paschal fire was seen, the heathen king was filled with anger, and the Druids said that if that fire was not put out before 
morning, it never would be put out. Accordingly they went to St. Patrick, but he preached the faith before them with such power and mighty signs and wonders, that though the king remained a "son of death," he granted St. Patrick freedom to preach the gospel in Ireland.

Ever since this time the shamrock has been the national emblem of Irishmen, and has been worn by them for many centuries on St. Patrick's Day, March 17.

Pliny, in his " Natural History," says that serpents are never seen upon the trefoil, and it prevails against the stings of snakes and scorpions; so, surely, no more suitable emblem could have been chosen by St. Patrick, as he is said to have driven all such hideous reptiles from the Emerald Isle.

The word "shamrock" (which means "little trefoil") is from the Erse "seamrog" and the Gaelic "seamrag," a diminutive of "seamar," trefoil.

The plant, which is figured upon our coins, both English and Irish, is an ordinary trefoil; Queen Victoria placed the trefoil in her royal diadem in lieu of the French fleur-de-lys.

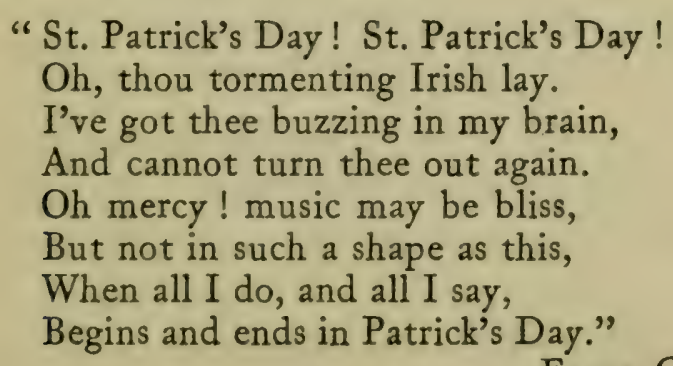

Eliza Cook. 


\section{THE GLORY OF THE GARDEN}

\section{The Leek, National Flower of Wales.}

"There is an aged cell, with moss and ivy grown, In which not to this day the sun has ever shone, That reverend British saint, in zealous ages past, To contemplation lived, and did so truly fast, As he did only drink what crystal Hodney yields, And fed upon the leeks he gathered in the fields; In memory of whom, in each revolving year, The Welshmen on his day that sacred herb do wear." Michael Drayton.

The leek has for many centuries been the emblem of Wales, and this is said to be in memory of a great victory obtained by the Welsh over the Saxons; upon which occasion they, by order of St. David, placed leeks in their caps. Thus the Welsh were all known to each other, while the Saxons, having no distinguishing mark, frequently mistook each other and slew friend and foe indiscriminately.

From this circumstance arose the custom of the Welsh wearing leeks in their hats on St. David's Day. Several of our oldest authors allude to this usage, and Shakespeare makes Henry V. acknowledge to the gallant Fluellen his pride of joining in the practice.

"I wear it for a memorable honour:

For I am Welsh, you know, good countryman."

Some of the old writers say that the leek is most truly the fitting emblem of Wales, combining white and green in its stems, which were the old Cymric colours.

St. David's Day falls on March I :

"March, various, fierce, and wild with wind-crackt cheeks, By wilder Welshmen led, and crown'd with leeks." 


\section{LEGENDS OF NATIONAL FLOWERS I67}

"I like the Leeke above all herbes and flowers,

When first we wore the same the field was ours;

The leeke is white and greene, whereby is ment

That Britons are both stout and eminent.

Next to the lion and the unicorne

The leeke's the fairest emblem that is worne."

\section{The Iris of France.}

" Though right be aft put down by strength,

As mony a day we saw that,

The Fleur-de-lis, that lost her right,

Is Queen again for a' that."

Sir WALter Scott.

The iris, or fleur-de-lys, has been for many years the emblematic flower of France, and was borne on the royal standard as the special national flower.

There is a legend that Clotilda, the wife of the war-like King Clovis, had long prayed for the conversion of her husband, and at length Clovis, having led his army against the Huns, and being in imminent danger of defeat, recommended himself to the God of his sainted wife. The tide of battle turned, he obtained a complete victory, and was baptised by St. Remigius.

On this occasion, owing to a vision of St. Clotilda, the iris was substituted in the arms of France for the three frogs or toads, which Clovis had hitherto borne on his shield.

In the pictures of St. Clotilda, she is generally represented as attended by an angel, holding a shield on which are the three fleurs-de-lys. This occurred early in the sixth century.

Louis VII., in consequence of a dream, assumed it as his device in $1 \times 37$, when engaged in the second 


\section{I68 THE GLORY OF THE GARDEN}

expedition of the Crusaders, and the iris flower soon became celebrated in France as the "Fleur-deLouis," which was first contracted into "Fleur-deLuce" and afterwards into "Fleur-de-lys" (lily flower), although it has no affinity to the lily.

"We'll twine her in a friendly knot

With England's Rose, and a' that;

The Shamrock shall not be forgot, For Wellington made braw that. The Thistle, though her leaf be rude, Yet faith we'll no misca' that, She sheltered in her solitude

The Fleur-de-lis, for a' that." Sir Walter ScotT. 


\section{CHAPTER XIX}

\section{LEGENDS OF MYTHOLOGICAL FAME}

\section{The Legend of the Poppy.}

"Stars they are, wherein we read our history,

As astrologers and seers of eld;

Yet not wrapped about with awful mystery,

Like the burning stars, which they beheld."

LONGFELLOW.

The true opium poppy (Papaver somniferum) has white flowers, with a large purple stain at the base of the petals.

Greek legend gives the origin of the plant thus:

When gathering flowers upon the plain of Enna, Persephone, "herself a fairer flower, by gloomy Dis was gathered," and Demeter, inconsolable for the loss of her daughter, set out to seek her throughout Sicily. As darkness falls, she hastens to Mount Etna, and at its flame lights two torches, wherewith to continue her search over all the world, and on her journeying she calls on the gods to aid her in her search and restore her lost child. They, powerless to do what she demands and yet moved to compassion by her grief:

"To soothe awhile the poignance of her woe, Large, heavy-headed poppies round her sow."

At sight of which she stoops and eats the juicefilled seeds, and heart and brain yield to the soothing 


\section{I70 THE GLORY OF THE GARDEN}

influence, and prone amid the flowers lies Ceres, dead to all present sense of loss and pain, sunk in that oblivion which it is the poppy's peculiar privilege to afford to suffering humanity.

The goddess Nox, or Night, and Thanatos, god of death, were crowned with poppies to propitiate them. Virgil writes of the Lethean poppy, and directs that it be offered as a funeral rite to Orpheus.

\section{A Bengali legend runs thus:}

Once, long ago, there lived on the bank of the Ganges a magician, in whose hut was born a mouse, who became a great favourite with the seer, and was gifted by him with the power of speech. After a time, the mouse, growing discontented with its lot, was transformed by the magician first into a cat, then a dog, ape, boar, and finally into a beautiful maiden, to whom he gave the name of Postimani, or poppy-seed lady.

One day, as she was tending her flowers, the king passed, and was invited in, and Postimani passed herself off as a princess whom the magician had found in the wood.

The king fell in love with her, and they were married by the seer, and lived a very happy life till, one day, as she was standing near a well, Postimani felt giddy, fell in, and was drowned. The seer, on hearing of the tragedy, came and told the king of the deception that had been practised upon him and said: "Let her body remain in the well, fill it up with earth, and out of the flesh and bones will grow a plant, which shall be called 'Posto,' the poppy tree. From this will be obtained a drug called opium, which will be either smoked or 


\section{LEGENDS OF MYTHOLOGICAL FAME I7I}

swallowed as a wonderful narcotic till the end of time.

" The use of this drug, if abused, will generate in the consumer one quality of each of the animals to which Postimani was transformed. He will be mischievous like a mouse, fond of milk like a cat, quarrelsome like a dog, filthy like an ape, savage like a boar, and high-tempered like a queen."

On account of the sleep-bringing qualities of the plant the Greeks, who regarded Hypnos as the greatest healer and consoler of human misery, represented him as crowned with poppies, and reclining on a bed of them. The poppy is the symbol of sleep, consolation, and death.

\section{The Legend of the Narcissus.}

On account probably of its poisonous qualities, the ancients regarded this beautiful plant as typical of deceit, and dedicated it to Demeter, and her daughter Hecate, the queen of Hades.

Some legends identify it with the flowers which Pluto caused to spring up to lure Persephone from her Sicilian home. As she stoops to gather the Elysian bloom, the whole plain quakes and trembles, and suddenly Dis appears, seizes Persephone, and places her in the waiting chariot, to bear her away to the gloomy kingdom of which she became queen. "Narcissus" is derived from the Greek word

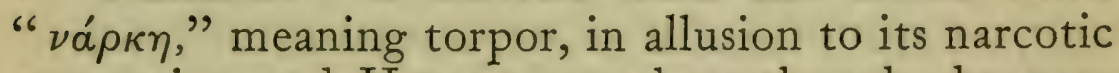
properties, and Homer says that, though the narcissus " delights heaven and earth by its beauty, yet at the same time it causes stupidity, madness, and even death." 


\section{THE GLORY OF THE GARDEN}

According to a Greek legend, the poetic narcissus owes its origin to a youth of this name, whom, to punish for his insusceptibility of heart, Nemesis caused to become so enamoured of his own face in the stream, that he fell in and was turned into a flower. When the weeping Echo and her sister nymphs, had prepared the funeral urn for him his body was missing.

The poetic Narcissus of classic fame is always therefore regarded as emblematic of self-love.

The botanical name of narcissus, having been given to the daffodil, has confounded it with the Greek narcissus, known in English by that name,

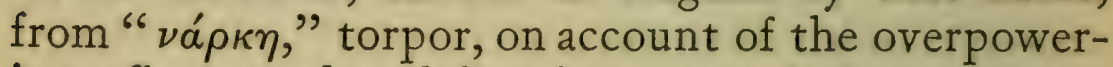
ing effect produced by the scent of the narcissus, a quality from which the daffodil is perfectly free.

The name of daffodil is simply the Old English " affodyll," or " that which cometh early," and it was many years before the word was corrupted into our present "daffodil."

\section{The Legend of the Mignonette.}

The word "Reseda," the generic name of the mignonette, is derived from the Latin verb resedare, to soothe.

Pliny states that the Reseda was considered to be possessed of the power to charm away many disorders, and it is doubtless owing to this traditional healing, as also to its delicious scent, that this fragrant little plant has come to be known as "the emblem of health!"

This idea accounts for Shelley's rather morbid reference in the lines: 
"Wherefore hast thou sent to me

Sweet basil and mignonette,

Embleming love and health, which never yet

In the same wreath were set."

Not only does the mignonette rejoice at the sight of the sun, but "follows with loving fidelity the attraction of his rays, from his rising to his setting," and it is a noticeable fact that at sunrise and sunset, its perfume is subtler and sweeter than during the daytime.

An ancient legend makes the bees responsible for the faint gold markings to be seen on each mignonette flower, giving us the story thus:

In very early days, the Reseda was an insignificant little plant, bearing only very small, plain, green flowers, which were scarcely distinguishable from leaves. Therefore she was always passed over by the bees, and felt their neglect very keenly, till one fine day a bee chanced to brush accidentally against a clump of mignonette, and was much astonished at the delicious perfume.

In hot haste he went to fetch his comrades to sample this wonderful new flower, but when they came and saw the plain green unpretentiousness of the mignonette, they were inclined to jeer, and to think their comrade had made fun of them. However, when they had tasted of the delicious nectar, they could only feel grief at their previous neglect of such delectable store, and as proof of their reparation they agreed to leave one drop each of the honey collected during the day, on each single flower of the Reseda. And so, from that day forward, the Reseda has jewelled the heart of her green flowers with those pale golden marks which 


\section{I74 THE GLORY OF THE GARDEN}

have made her one of the most sought after of all blossoms.

\section{The Legend of the Violet.}

"Spring's little infant" has been emblematic of romance, poetry, chivalry, and love. With the ancients it was regarded as the flower of honour, and may be found in practically all parts of the world. Several classic legends account for the origin of the violet. Ianthea, one of the brightest of Diana's nymphs, was changed into a blue violet to save her from the wiles of the sun god. Another legend says the violet was once a young priestess of Juno's temple, called Io, whom Jupiter, to protect from the jealous anger of his consort, had transformed into a cow. And "when she in hunger stoops in tears," even as her lips meet the grass there springs to her breath the first white violet.

According to another old legend, the violets were all white till one day Venus, envious of Cupid's admiration of their purity and sweetness, turned them blue.

\section{The Legend of the Veronica.}

Our little blue-eyed speedwell has a very good name among the plant myths and legends, as it was renowned with magic powers and healing properties, and given first rank among the vulnerary plants. One early legend says that a shepherd noticed how a stag, bitten by a wolf, first rubbed his wound against an oak, and then went to a place where veronica grew. Here he remained for a week, eating at intervals of the plant, after which he reappeared 


\section{LEGENDS OF MYTHOLOGICAL FAME I75}

cured of his wound. Upon this the shepherd prepared a vessel full of the healing flowers and set out for the palace, where the king lay dying of leprosy, and in due course that monarch was cured by the healing virtues of the veronica.

The generic name is an altered form of the Latin $V$ era icon-true image, bestowed because the flowers of the plant were said in olden days to display in their forms and markings, the representation of St. Veronica's handkerchief, with which she was privileged to wipe the face of Our Lord.

\section{The Legend of the Myrtle.}

Eastern fable tells us that in olden days the rose herself named the myrtle the "Prince of odoriferous Plants." Like the rose, the myrtle is emblematic of love, and, according to classic tradition, possesses not only the power to inspire, but also to retain love. So the ancients dedicated the myrtle to Venus, whom they worshipped under the name of Myrtea, and to whom they consecrated a temple, enclosed in a grove of myrtles. The Graces, when in attendance upon Venus, were crowned with myrtle, and votaries, when sacrificing to their goddess, wore myrtle chaplets.

From one of the myths we learn that when Aphrodite sprang from the foam of the sea she was met by the Seasons, who presented her with a rainbow-coloured scarf and a wreath of myrtle, and when later, in order to subjugate Paris, and win from Hera and Pallas the prize of beauty, she "bathed in all the blossoms that the Seasons bring," and "clothed her gracious form in raiment that the 


\section{I76 THE GLORY OF THE GARDEN}

Hours and Graces wrought," it was myrtle that the lovely goddess selected wherewith to wreathe her brows. When pursued by a band of satyrs, who had found her seated by the sea waves combing her hair after bathing, it was to a grove of myrtles that the startled goddess ran for protection. Also, it was with a myrtle rod that she, as the queen of beauty, caused Psyche to be chastised, for daring to outrival her own heaven-born charms, in the eyes of Cupid.

The Greeks were devoted to the myrtle, and dedicated it to Mars, god of war, and frequently coupled it with the laurel, symbol of glory and honour; but it was only after a bloodless victory that the conquerors wreathed their swords with myrtle.

There is an old tradition that the myrtle was the only plant borne away from the Garden of Eden:

"No blossom from their garden bore away

Save one, that Adam snatches by the gate, A myrtle spray."

\section{The Legend of Christmas Decorations.}

There is an interesting legend giving a probable reason for the decoration of houses with mistletoe and holly, and it would seem that the custom is of Druidic origin.

For it comes down to us on good authority that, in the times of the Druids, the houses were decked with boughs and branches in order that the spirits of the forest might seek shelter among them, during the bleak winds and frosts of the winter. How 
many people in these materialistic days think of this, when they adorn their houses with these old historic plants?

\section{The Legend of the Mistletoe.}

According to Scandinavian mythology, Baldr (the Apollo of the North) was rendered by his mother Frigg, proof against all injury by the four elements, fire, air, earth, and water. Loki, the evil spirit, being at enmity with him, fashioned an arrow out of mistletoe (which proceeded from neither of the elements), and placed it in the hand of Hodr, the blind deity, who launched the fatal dart at Baldr, and struck him to the earth. The gods decided to restore Baldr to life, and as a reparation for his injury the mistletoe was dedicated to his mother Frigg, while, to prevent it being used adversely against her, the plant was placed under her sole control, so long as it did not touch the earth, the empire of Loki. On this account it has always been customary to suspend mistletoe from ceilings, and so it became a habit for persons of opposite sexes, passing under the mistletoe, to give one another the kiss of peace and love, in the full assurance that this plant is no longer an instrument of mischief.

The old astrologers affirmed that a sprig of mistletoe worn round the neck was a talisman against all witchcraft, always and only providing that the bough had not been allowed to touch the earth after being gathered.

The Holly is always used in company with the mistletoe for Christmas decorations, and the custom 


\section{I78 THE GLORY OF THE GARDEN}

is probably derived from the ancient Romans, who used to send boughs to their friends during the feast of the Saturnalia, which occurred about the same period, and the oaks being then bare of leaves, the priests instructed the people to bring in branches of holly and evergreens. There is evidence that the early Christians, disregarding the Church's interdiction on this matter, introduced the heathen practice of decorating their houses with holly, and in course of time it came to be duly connected with the Christian observance of Christmas.

There is an old English superstition that elves and fairies join the social gatherings at Christmas, and this led to branches being hung in halls and entrances in order that "the fays might hang in each leaf, and cling to every bough during that sacred time when spirits have no power to harm."

These decorations must be taken down on Candlemas Eve:

"Down with the holly and ivy all

Wherewith ye deck the Christmas hall;

So that the superstitious find

Not one least branch there left behind;

For look, how many leaves there be

Neglected there-maids, tend to me-

So many goblins ye shall see."

The disciples of Zoroaster, or fire-worshippers, believe that the holly tree casts no shadow, and both in Persia and India they employ an infusion of its leaves for several purposes of their religious observances. Pliny states that if the holly be planted near a house it will keep away all malign spells 


\section{LEGENDS OF MYTHOLOGICAL FAME I79}

and enchantments, and defend the house from lightning.

"Should you ask where Nawadaha

Found these songs so wild and wayward,

Found these legends and traditions,

I should answer, I should tell you,

'In the birds' nest of the forest,

In the lodges of the beaver,

In the hoof-prints of the bison,

In the eyrie of the eagle!"'

LONGFELLOW: The Song of Hiawatha. 


\section{CHAPTER XX}

\section{LEGENDS OF FIR AND PINE TREES}

"Ye who love the haunts of Nature, Love the sunshine of the meadow, Love the shadow of the forest, Love the wind among the branches, And the rain-shower and the snow-storm, And the rushing of great rivers Through their palisades of pine-trees, And the thunder in the mountains, Whose innumerable echoes Flap like eagles in their eyriesListen to these wild traditions."

Longfellow: The Song of Hiawatha.

PINES and Firs, sombre sentinels of the woods, are more interwoven with myth and legend than any other tribe of trees, and their stately grandeur has appealed especially to the hearts of men through all the ages.

In olden days the fir was always called the "Firetree," being the most inflammable of all woods, the reason being that it is so full of resin that upon being lighted it will burn like a torch. Tradition tells us that the ancient Egyptians adopted a fir cone as the symbol of their goddess Isis, and in the Northern countries the fir occupies a very respected position: he is the king of the forest trees, and thus in the old folk-lore the genii of the forest are always depicted with an uprooted fir tree in their hands. These genii make their dwellings 


\section{LEGENDS OF FIR AND PINE TREES I8I}

in fir trees, and by preference old trees, and if by chance one of these trees is cut down the genii grieve, and are extremely sad.

There is a legend of a colossal fir tree which grew by itself at Tarssok, in Russia.

It was said to be several hundred years old, and had withstood many blasts of lightning, as shown by its barkless trunk and bare branches.

At last in a gale of wind it fell, but so great was the respect and veneration felt by the countryfolk for this fine old tree, that they would not make any profits from the sale of the immense trunk, but gave the proceeds to the Church.

In Denmark, Sweden, Russia, and Germany, it has been the custom for a great number of years, to use the fir exclusively as the Christmas-tree, and this custom and idea has now become firmly established in England.

The Pine Tree was dedicated to Bacchus, and this connection is still maintained by the Greeks, who put pine cones in their wine vats, to preserve and flavour the wine, by means of the resin contained in the cones.

The pine cone was considered a symbol of the heart of Zagrœus, who was destroyed by the Titans, and whose ashes were given to Semele, the mother of Bacchus.

In some localities the pine was also dedicated to Pan, because Pitys, a nymph whom he loved, was changed into a pine tree, to escape the importunities of Boreas.

The wood of the pine was used in making the first boats, and so the tree was also dedicated to Neptune, the great sea god; therefore, being held sacred to 
three of the greatest mythological deities, it is small wonder that the pine has been held in special veneration by mortal men, through all the changing vistas of the centuries.

The pine, and all the allied coniferous tribe, are usually regarded as funereal trees, and symbolise immortality, hence the reason for planting them in churchyards and round about the church. Especially is this the case with the yew, which from the remotest past has been always associated with the shade and solitary quiet of the churchyard. Far from adding an air of sombreness, as is suggested by some writers, the presence of these calm sentinels gives an extraordinary air of quiet peace, of something perpetually alive, though at rest.

The Egyptians regarded the yew as a symbol of mourning, and the idea descended to the Greeks and Romans, who employed the wood as fuel for their funeral pyres.

The ancient Britons probably learnt from the Romans to attach a funereal significance to the yew, and hence in course of time it came to be planted in churchyards, and on account of its evergreen nature was considered as a symbol of immortality and resurrection.

Virgil attributed the notoriously unwholesome quality of the honey of Corsica, to the bees feeding upon the yew flowers, and cautions bee-keepers to be careful that no yew trees grow near their hives.

The Cypress is another tree that in all countries from the very earliest times has been regarded as the emblem of woe. Gerarde tells us that it had the reputation of being deadly, and that its shadow was 
unfortunate. Horace, Virgil, and Ovid all refer to it as a tree both gloomy and funereal.

But in spite of all this, the cypress has been most highly esteemed as an undying tree, both evergreen and odorous, and a tree of which the wood, like the cedar, is incorruptible, and proverbial for its durability. It was on this account that the people of Athens employed it in making coffins for their heroes, and also statues of their gods.

The imperishable chests containing Egyptian mummies were made of cypress wood, and also the gates of St. Peter's at Rome, which have lasted for a period of eleven hundred years, during which time they suffered no decay.

Ovid tells us of the "taper cypress" that it is sacred to Apollo, and was once a fair youth, Cyparissus by name. This youth became much attached to a gentle stag, who was his constant companion, and was one day unwittingly pierced to the heart by an arrow from the hand of the unlucky youth.

Overcome with remorse, Cyparissus would have killed himself but for the intervention of Apollo, who bade him not mourn to such excess. Unable, however, to conquer his grief, he prayed to the gods, who turned him into a cypress tree, that he might mourn for all succeeding time.

A very ancient legend, contained in the "Gospel of Nicodemus," gives us much interesting information concerning the cypress. Adam one day fell ill, and he sent his son Seth to the Garden of Eden, to ask the Guardian Angel for some drops of the oil of mercy distilled from the Tree of Life. The angel replied that none could have that till 5,000 years had passed, but gave him a slip of the tree, 
which was afterwards planted on Adam's grave, and grew into a goodly tree with three branches.

Another version of the story is that the angel gave Seth three seeds, from which grew the cypress, the cedar, and the pine. These were later on carried away by Moses, who cut his rod from them, and King David transplanted them near a fountain at Jerusalem, and under their shade composed the Psalms and lamented his sins. Solomon afterwards cut the tree down for a pillar in the Temple, but none could fix it there.

It was then buried in the pool of Bethesda, thereby accounting for the healing properties of the waters. At the Passion it floated, and was taken for the Cross, or, as some say, for the upright beam. Some versions of the legend of the wood of the Cross, state it was made of cypress, cedar, pine, and box. One names cypress for the body, palm for the hands, cedar for the support of the feet, and olive for the superscription.

Another version states that the cross-beam was of cypress, the upright beam of immortal cedar, the title of olive, and the foot-rest of palm, and from this arises the line:

"Ligna crucis palma, cedrus, cupressus, olivia."

The Cedar has always been regarded as a sacred tree, and many historical references are made concerning it from the very earliest times. Josephus tells us that the Cedar of Lebanon was first planted in Judæa by Solomon, who greatly admired this noble tree, and built himself a palace of cedar of Lebanon itself. 


\section{LEGENDS OF FIR AND PINE TREES I 85}

The celebrated Temple of Solomon was built of hewn stone, lined with cedar, which was "carved with knops and open flowers; all was cedar, there was no stone to be seen." The Jews always regarded the cedar as a sacred tree, so it was employed for making their carven images.

According to the ancient Chaldean magicians, the cedar is a tree of good omen, protecting the good, and overthrowing the machinations of evil spirits.

The Juniper in olden times was often called a cedar, and these two distinct species were much confounded, although Pliny distinguishes between the two. Thus Virgil is supposed to have meant the cedar when he says in the "Georgics":

"But learn to burn

Within your sheltering rooms

Sweet juniper."

The juniper was consecrated to the Furies; the smoke of its green roots was the incense which the ancients deemed most acceptable to the infernal gods, and they burned its berries during funerals to ban malign influences. The juniper has always been looked upon as a protective tree; its powerful odour will puzzle the keen scent of the hounds, and a hunted hare will thus find a safe retreat in the cover of its branches.

In Italy, branches of juniper are hung on Christmas Day in churches and houses, just as universally as holly is employed in England.

There was a belief, common among the ancients, that the burning of juniper wood expelled evil spirits, and we find evidence of this in some parts of Scotland, where it was customary during an 


\section{I86 THE GLORY OF THE GARDEN}

epidemic to burn juniper wood, with certain weird and mysterious ceremonies. In Italy and Germany, the juniper has always been the object of a superstitious reverence, on account of its power for dispersing evil spirits.

Also the stables were preserved from the power of demons and thunderbolts by means of a sprig of juniper, just as our own houses and stables used to be preserved from the power of witches, through the magic horseshoe.

In Tuscany, the juniper receives a special blessing on Palm Sunday; and in Venetia, juniper is burnt to purify the air, thus recalling the ancient Roman custom of burning it instead of incense on the altars.

The smoke of the leaves and wood was said to drive away serpents, " and all infection and corruption of the aire which bring the plague, or such-like contagious diseases."

The Larch, with the delicate beauty of its fresh green branches, is one of the most beautiful sights which delight our eyes and hearts in the early springtime. There has long been a superstitious belief that the wood of the larch tree is impenetrable by fire, and the story is told by Vitruvius of a castle besieged by Cæsar, which was built largely of larchwood, and was therefore most difficult to consume.

In the case of a forest fire, if larches are scorched to the pith, the inner part exudes a gum, and Ben Jonson, in the "Masque of Queens," speaks of this gum or turpentine of the larch, as being used in witchcraft.

Among all these ancient and some more modern myths and legends, one feels how good and necessary it is to step aside now and again, from the present- 


\section{LEGENDS OF FIR AND PINE TREES I87}

day rush and turmoil, into the secluded paths of garden fact and fantasy.

It is good surely to spare some time for these fairy tales of Nature, relics of a time when the world was younger and more trusting, an idea brought out very beautifully by a writer who calls himself "A Pilgrim in Fairyland " in a poem entitled:

\section{THE SECRET OF THE PINE-TREES}

"I was dreaming on a woodland hill, And as I lay listening very still

An angel vision came to me

Of the first beginning of every tree.

And this is what I heard and saw

Through the fairy mind-the Open Door.

"Long ago in the first earth day

When the trees were young and full of play,

Just fresh new-born from God's great heart,

To live their life and take a part

In that wise, loving, mysterious plan

Which was crowned by our creation-Man .

The trees, I tell you, were full of play

In this glad youth-time of their day;

They sang and swung in child-like glee,

Waving their branches strong and free.

Then suddenly they were silent and still;

A hush was over each valley and hill.

For He, the Creator, God, drew near,

Wanting to speak to His children dear.

His children of Green Earth glad and gay,

Where fear was not, and where fairies play.

Then He called to the seasons He had made

To come and show themselves displayed, So that the trees and flowers would know

What change they had to undergo.

First came Spring, just dancing down,

Clad in yellow cowslip and bluebell gown; 
Then Summer with roses and happy face;

Then Autumn in many-tinted grace.

Last came Winter riding by

On a snow-flaked horse, with a whistling cry.

And when the trees saw him go past,

And felt the icy, chilling blast,

They shivered, and then they seemed to say

To their loving Creator, 'Must we stay?'

And $\mathrm{He}$ smiled lovingly, and said,

'In Winter you all shall sleep instead.'

But the Pine trees listening heard Him sigh, And looked at each other, wondering why, And asked Him, 'Master, do you sleep, too, All the cold, long winter through ?'

$\mathrm{He}$ answered, 'I never slumber, nor sleep,

I ever a vigilant watch must keep.'

'May we,' they whispered, ' watch with you ?'

'Yes,' He said, ' if your love is true,

For the cost is great, you can never be seen

In a fresh and gay Spring dress of green;

The darkest armour you must wear,

In Winter storm or Summer glare."

' Gladly,' they cried, ' we'll give up all

That we may be sentinels at your call.'

"And because of the sacrifice they have made,

These trees, so strong and unafraid, They have learnt the secret of the sea, And can sing its song to you and me, The song of Perfect Peace through pain,

Which only Jesus can explain." 




\section{QK87.K4 \\ Kennedy-Bell, M. G./The glory of the gar \\ TIIIIIII \\ (1) \\ 35185000890572}


